Universidade de Brasília

Instituto de Ciências Humanas

Departamento de Geografia

Programa de Pós-Graduação em Geografia

UNIVERSIDADE DE BRASÍLIA

PÓS-GRADUAÇÃO EM GEOGRAFIA

Mensuração de perdas de sedimentos por escoamento superficial em encostas, com uso de parcelas de erosão, em diferentes usos e coberturas do solo no Bioma Cerrado: Bacia Hidrográfica do Ribeirão do Gama/DF

Marina Almeida Mesquita Oliveira

Dissertação de Mestrado 
Universidade de Brasília

Instituto de Ciências Humanas

Departamento de Geografia

Programa de Pós-Graduação em Geografia

UNIVERSIDADE DE BRASÍLIA

PÓS-GRADUAÇÃO EM GEOGRAFIA

Mensuração de perdas de sedimentos por escoamento em diferentes usos e coberturas da terra no Bioma Cerrado: Bacia Hidrográfica do Ribeirão do

Gama/DF

Marina Almeida Mesquita Oliveira

Orientador:

Rogério Elias Soares Uagoda

Dissertação de Mestrado

Brasília-DF: julho/2015 
Universidade de Brasília

Instituto de Ciências Humanas

Departamento de Geografia

Programa de Pós-Graduação em Geografia

\author{
UNIVERSIDADE DE BRASÍLIA \\ PÓS-GRADUAÇÃO EM GEOGRAFIA
}

Mensuração de perdas de sedimentos por escoamento em diferentes usos e coberturas da terra no Bioma Cerrado: Bacia Hidrográfica do Ribeirão do

Gama/DF

Marina Almeida Mesquita Oliveira

Dissertação de Mestrado submetida ao Departamento de Geografia da Universidade de Brasília, como parte dos requisitos necessários para a obtenção do Grau de Mestre em Geografia, área de concentração Gestão Ambiental e Territorial, opção Acadêmica.

Aprovado por:

Rogério Elias Soares Uagoda, Doutor (Dep. de Geografia - UnB)

(Orientador)

Mario Diniz de Araújo Neto, Doutor (Dep. de Geografia - UnB)

(Examinador Interno)

André de Sousa Avelar, Doutor (Dep. de Geografia - UFRJ)

(Examinador Externo)

Brasília-DF, 30 de julho de 2015. 
Universidade de Brasília

Instituto de Ciências Humanas

Departamento de Geografia

Programa de Pós-Graduação em Geografia

OLIVEIRA, MARINA ALMEIDA MESQUITA.

Mensuração de perdas de sedimentos por escoamento superficial em encostas, com uso de parcelas de erosão, em diferentes usos e coberturas do solo no Bioma Cerrado: bacia hidrográfica do Ribeirão do Gama/DF, 78 p., 297 mm, (UnB-GEA, Mestre, Gestão Ambiental e Territorial, 2015).

Dissertação de Mestrado - Universidade de Brasília. Instituto de Ciências Humanas, Departamento de Geografia.

1. Hidrologia de encostas

2. Erosão

3. Escoamento superficial

4. Cerrado

\section{UnB-GEA-IH}

É concedida à Universidade de Brasília permissão para reproduzir cópias desta dissertação e emprestar ou vender tais cópias somente para propósitos acadêmicos e científicos. O autor reserva outros direitos de publicação e nenhuma parte desta dissertação de mestrado pode ser reproduzida sem a autorização por escrito do autor. 


\section{DEDICATÓRIA}

À doce Beatriz, que veio como um beija-flor, Sentiu o mel do amor e voou pra outro lugar (in memorian).

Ao meu querido Edclei por todo carinho, dedicação e gentileza. Ao meu amado filho por sua alegria de viver e seu bom coração. 


\section{GRATIDÃO}

Em primeiro lugar, sou grata a Deus e ao Grande Mestre pela oportunidade de aprender, crescer e ser feliz.

Grata ao meu companheiro, Edclei, amigo de todas as horas, que me auxilia e apoia. Sou grata ao nosso filho, Bruce, por seu amor, carinho e alegria.

Pai e mãe, sou grata por minha vida, pela criação que me deram e o apoio, acreditando em minha capacidade de vencer as dificuldades, mesmo quando eu mesma não acreditava.

Sou grata aos meus irmãos Rafael, Mariana e Cecília, pela amizade e por estarem sempre ao meu lado.

Sou grata aos meus sogros Aldeni Rodrigues Araújo Oliveira e Luiz Gonzaga Sampaio Oliveira por todo apoio que me deram cuidando do meu filho e da minha casa quando não podia dedicar-me a eles.

Sou grata ao meu orientador, Rogério Elias Soares Uagoda, por sua orientação, conhecimento e, que antes de ser meu professor-orientador, é um amigo e um parceiro na luta pelo fortalecimento da ciência Geográfica.

Aos professores André de Sousa Avelar e Mário Diniz de Araújo Neto pela paciência fazendo parte desta banca.

Ao professor Roberto Arnaldo Trancoso Gomes pela participação na banca de qualificação.

À minha amiga Tatiana Diniz Gonçalves e à minha tia Irene pelo constante apoio e encorajamento no meu aprimoramento profissional e pessoal.

Ao Bruno Esteves Távora, minha sincera gratidão. Sem ele, muito do que foi feito neste trabalho não teria acontecido. Grata pelos conhecimentos, força de trabalho e amizade.

Aos meus queridos parceiros de caminhada da pós-graduação Ligier, Isabel, Ane Carolina, Maribel, Isabel Cristina, Juliana, Núbia, Thomas, Paulo Henrique, Daniel, Rafael, Elisa e Eudes. A amizade e a companhia de vocês tem feito o caminho ser mais alegre de trilhar. 
Aos graduandos Áquila, Érika, Isabela Resende, Nathália, Rogério Vidal, Raina, Renan, Dandara e Lucas pelo auxílio que me prestaram na montagem de equipamentos, coleta e análise de amostras. Destaco o Flávio que foi meu braço direito neste trabalho.

Ao Professor e Diretor Diogo, Ramon, Cana Verde, Sr. Augusto, Vasco, Daniel, Iara, Luciano, Gustavo, Prof. Fagioli, Ronaldo, Sr. Machado, Nice, contar com a presença e o auxílio de vocês na Fazenda Água Limpa deixaram as atividades de campo mais leves e alegres.

Ao Antônio Marcos, Eluziano, João, Luis, Glaucia, Ivonete, Jesiel, Cláudio, Ronildo, Sr. Carlos pela presteza em me auxiliar no que precisei, seja confeccionando materiais, seja nos levando e trazendo da Fazenda Água Limpa, ou auxiliando nas atividades de campo.

Aos professores e funcionários do Departamento de Geografia pelo conhecimento e pelo auxílio prestado.

Aos professores Sergio Koide, Henrique Roig e Hernán Carvajal pesquisadores integrantes dos grupos de pesquisa Geomorfologia e Evolução da Paisagem e de Estudos Hidrológicos e Hidráulicos.

Ao CNPq pela bolsa de estudos.

Aos meus colegas do IPEA, Erivelton Pires, Fábio Schiavinatto, Fábio Alves, Ane Carolina, Joana Carolina, Juliana Geina, Amanda Gonçalves, Luiza Moretti, Andrei Cornetta, Leonard Grala, José Roberto, onde fui bolsista antes de receber a bolsa do CNPq, pela oportunidade de crescimento e de poder conhecer mais o nosso país. 


\section{RESUMO}

O Bioma Cerrado tem grande relevância no país por sua elevada biodiversidade e por abrigar as nascentes de três importantes bacias hidrográficas brasileiras, do Paraná, do São Francisco e Tocantins-Araguaia. A vegetação do cerrado é fortemente influenciada pelo tipo e profundidade do solo, e pelo regime climático. A intensificação das alterações da cobertura e do uso da terra podem provocar o incremento do escoamento superficial e da erosão, e diminuição da infiltração da água no solo. A mensuração dos valores de escoamento superficial, de infiltração e de erosão é de fundamental importância na prevenção de desastres naturais, ambientais e sociais, nas práticas de conservação do solo e dos corpos hídricos, e no planejamento urbano e rural. A precipitação foi medida por meio de pluviômetros e a mensuração das variáveis infiltração e escoamento superficial, e também de produção e transporte sedimentar, foi feita utilizando-se as parcelas hidro-erosivas, ou de erosão. Esta dissertação tem como objetivo mensurar a produção de sedimentos causados por escoamento superficial em encostas no Bioma Cerrado com a instalação de 15 (quinze) parcelas de erosão, em cinco áreas distintas - gramínea simulando o uso urbano, solo exposto, cultivo de café plantado em curvas de nível, Cerrado e Mata Ciliar -, sendo três em cada área, na Bacia do Ribeirão do Gama, DF. A perda de sedimentos (toneladas/ha.ano) será calculada por uma alíquota de $1000 \mathrm{ml}$ do total de escoamento superficial. Os resultados são apresentados em artigo específico e demonstram a maior perda de sedimentos nos locais com alteração da cobertura original do solo e com chuvas de maior intensidade. 


\begin{abstract}
The measurement of runoff, percolation and surface erosion is central to the prevention of natural hazards, soil conservation and rural/urban planning. The rainfall is measured by manual and automatic rain gauges. Numbers of percolation and surface erosion can be obtained by erosion plots. Installation criteria are necessary to the measurement, as such: inclination between $5^{\circ}$ and $20^{\circ}$; easy access; disctints land use and phytophysiognomy.

This work ains to study the sediment production regulated by runoff in the cerrado (savana) biome. We have been installed 15 microplots in 5 disctints uses ( 3 for area): grass, exposed soil, coffee plantation, cerrado (savana) and riparian forest, on the Gama basin/DF. The soil loss (tons/he/year) will be obtained by with an aliquot of $1000 \mathrm{ml}$. The results are presented in a specific paper. They shown a greater soil loss on the uncovered areas and during heavy rainfall.
\end{abstract}




\section{SUMÁRIO}

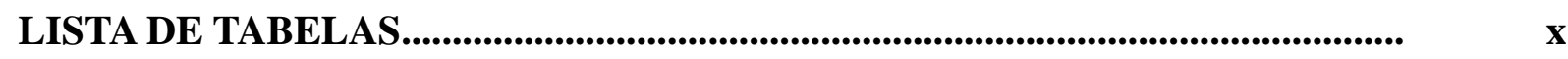

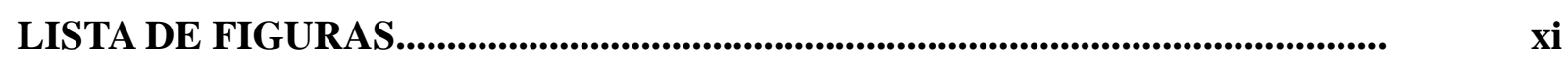

LISTA DE ABREVIATURAS, SIGLAS E SÍMBOLOS..................................................... xiii

1. INTRODUÇÃO ........................................................................................... 14

1.1 CARACTERIZAÇÃO DA ÁREA DE ESTUDO....................................................... 17

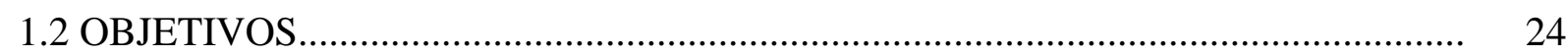

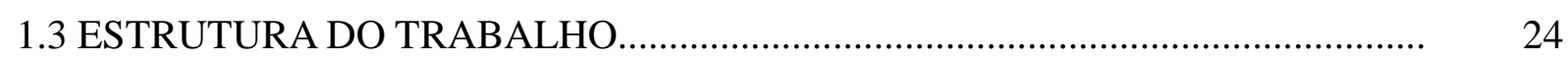

2. REFERENCIAL TEÓRICO............................................................................ 26

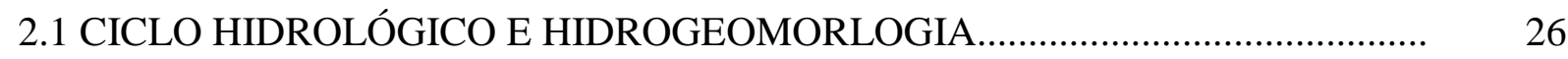

2.2 MENSURAÇÃO HIDROLÓGICA E DA PERDA DE SEDIMENTOS..................... 33

2.3 BIOMA CERRADO: FITOFISIONOMIAS, CLIMA E CARACTERÍSTICAS DOS SOLOS

3. MATERIAIS E MÉTODOS ........................................................................................

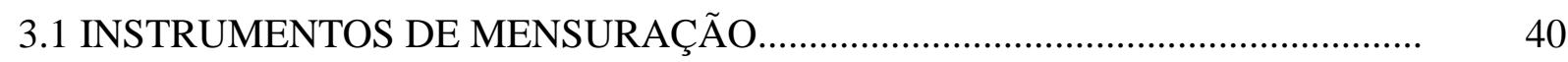

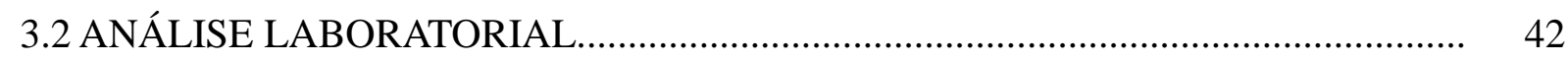

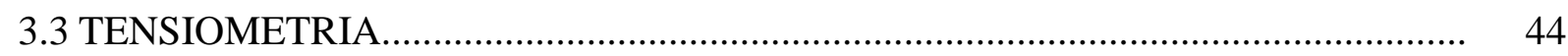

4. MENSURAÇÃO DE PERDAS DE SEDIMENTOS POR ESCOAMENTO SUPERFICIAL EM DIFERENTES USOS E COBERTURAS DO SOLO NO BIOMA CERRADO: BACIA HIDROGRÁFICA DO RIBEIRÃO DO

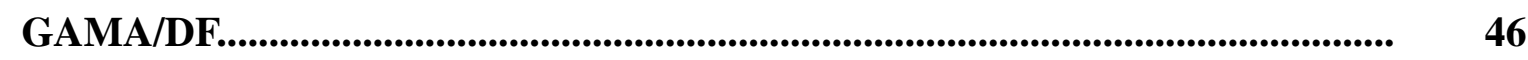

REFERÊNCIAS BIBLIOGRÁFICAS................................................................... 73 


\section{LISTA DE TABELAS}

Tabela 3.1 - Guia para interpretação de leituras de tensiômetros 45

Tabela 4.1 - Distribuição granulométrica dos solos das parcelas. 56

Tabela 4.2 - Períodos de coleta, Precipitação acumulada do período, Número de dias do período, Número de dias com chuva, Classes de chuva - Pluviômetro CAP 01. 58

Tabela 4.3 - Períodos de coleta, Precipitação acumulada do período, Número de dias do período, Número de dias com chuva, Classes de chuva - Pluviômetro FAL-UNB .........58

Tabela 4.4 - Total de massa de sedimentos transportada por área $\left(\mathrm{g} / \mathrm{m}^{2}\right)$ 69

Tabela 4.5 - Precipitação (P), Escoamento Superficial (Q), Infiltração (I), Perda de Sedimentos (S), Declividade (D) e Porcentagem de Argila (\%) por $\mathrm{m}^{2}$, por Uso do Solo 


\section{LISTA DE FIGURAS}

Figura 1.1 - Localização da Bacia Hidrográfica do Ribeirão do Gama. ................................... 18

Figura 1.2 - Distribuição de classes de solo - Bacia do Ribeirão do Gama/DF.

Figura 1.3 - Distribuição dos tipos e classes de uso do solo - Bacia do Ribeirão do Gama/DF.

Figura 1.4 - Hipsometria da Bacia do Ribeirão do Gama/DF.................................................2

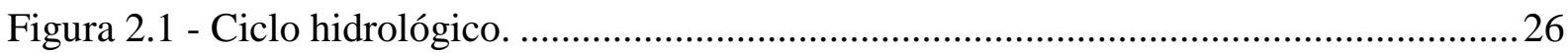

Figura 2.2 - Componentes da interceptação: P é a precipitação; ET é a evapotranspiração; A é o armazenamento nas copas; At é o atravessamento nas copas; e F, é o fluxo de tronco. 29 Figura 2.3 - a) escoamento superficial hortoniano (HORTON, 1934) e escoamento superficial em áreas de saturação .

Figura 2.4 - Exemplos de processos erosivos condicionados por diferentes fluxos hídricos .. 32

Figura 2.5 - Parcela hidro-erosiva, ou de erosão. 34

Figura 3.1 - [A] Parcela de erosão na Estação Gramínea com pluviômetro artesanal ao lado;

[B] Balde e agitador para agitação da amostra; [C] Bateria de tensiômetros instalada na Estação Gramínea; [D] Coleta de escoamento superficial e de sedimentos na Estação Café - Fazenda Água Limpa. 41

Figura 4.1 - Localização de cada estação de trabalho - Fazenda Água Limpa..........................52

Figura 4.2 - Parcelas de erosão em Gramínea .......................................................................55

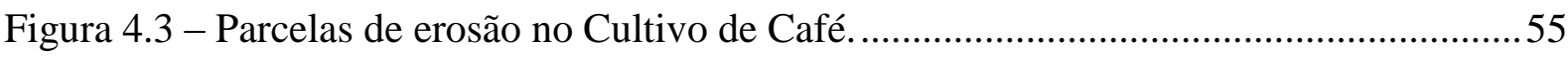

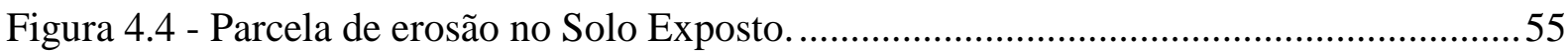

Figura 4.5 - Parcela de Erosão na Mata de Galeria..................................................................55

Figura 4.6 - Parcela de erosão no Cerrado - fase de instalação. .............................................. 55

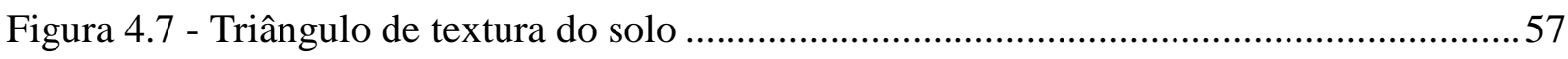

Figura 4.8 - Gráfico de correlação entre precipitação do pluviômetro CAP 01 e o fluxo de atravessamento médio medido pelos pluviômetros artesanais da Mata de Galeria [A] e Cerrado [B].

Figura 4.9 - Gráfico da Razão Escoamento Superficial (Q) e Precipitação (mm) das parcelas de erosão por tipo de uso do solo - \%

Figura 4.10 - Gráfico Relação Precipitação Diária, Precipitação Acumulada do período da coleta, Intensidade Diária $(\mathrm{mm} / \mathrm{h})$ - pluviômetro CAP 01, Escoamento Superficial e 
Produção de Sedimentos - Estações Mata de Galeria [a] e Cerrado [b]. A seta em vermelho representa um conjunto de amostras que foram perdidas durante o processo de análise, referentes à coleta do dia 24/01/2015.

Figura 4.11 - Gráfico Relação Precipitação Diária, Precipitação Acumulada por período de coleta, Intensidade Diária $(\mathrm{mm} / \mathrm{h})$ - pluviômetro FAL-UNB, Escoamento Superficial e Produção de Sedimentos - Estações [c] Café, [d] Gramínea e [e] Solo Exposto. 63

Figura 4.12 - Gráfico Relação Precipitação diária (mm) e Tensão da Água no Solo (kPa) profundidades $10 \mathrm{~cm}, 20 \mathrm{~cm}$ e $45 \mathrm{~cm}$ - estação Mata de Galeria.

Figura 4.13 - Gráfico Relação Precipitação diária (mm) e Tensão da Água no Solo (kPa) profundidades $10 \mathrm{~cm}, 20 \mathrm{~cm}$ e $45 \mathrm{~cm}$ - estação Cerrado.

Figura 4.14 - Gráfico Relação Precipitação diária (mm) e Tensão da Água no Solo (kPa) profundidades $10 \mathrm{~cm}, 20 \mathrm{~cm}$ e $45 \mathrm{~cm}$ - estação Café.

Figura 4.15 - Gráfico Relação Precipitação diária (mm) e Tensão da Água no Solo (kPa) profundidades $10 \mathrm{~cm}, 20 \mathrm{~cm}$ e $45 \mathrm{~cm}$ - estação Gramínea. 66

Figura 4.16 - Gráfico Relação Precipitação diária (mm) e Tensão da Água no Solo (kPa) profundidades $10 \mathrm{~cm}, 20 \mathrm{~cm}$ e $45 \mathrm{~cm}$ - estação Solo Exposto.

Figura 4.17 - Gráfico de Caixa com a distribuição dos valores do escoamento superficial (L) por parcela de erosão, por tipo de uso do solo.

Figura 4.18 - Gráfico de caixa com a distribuição dos valores da produção de sedimentos $(\mathrm{g} / \mathrm{L})$ por parcela de erosão, por tipo de uso do solo 68 


\section{LISTA DE ABREVIATURAS, SIGLAS E SÍMBOLOS}

$\begin{array}{ll}\text { ANA } & \text { Agência Nacional de Águas } \\ \text { Caesb } & \text { Companhia de Saneamento Ambiental do Distrito Federal } \\ \text { Cb } & \text { Centibar } \\ \text { CE } & \text { Cerrado } \\ \text { CF } & \text { Café } \\ \text { CNPQ } & \text { Conselho Nacional de Desenvolvimento Científico e Tecnológico } \\ \text { EUPS } & \text { Equação Universal de Perda de Solos } \\ \text { FAL } & \text { Fazenda Água Limpa } \\ \text { g } & \text { Grama } \\ \text { GR } & \text { Gramínea } \\ \text { Infralab } & \text { Laboratório de Estruturas e Construção Civil } \\ \text { km² } & \text { Quilômetro quadrado } \\ \text { km }{ }^{3} & \text { Quilômetro cúbico } \\ \text { kPa } & \text { Quilopascal } \\ \text { LAGEF } & \text { Laboratório de Geografia Física } \\ \text { L } & \text { Litro } \\ \text { mm } & \text { Milímetro } \\ \text { m² } & \text { Metro quadrado } \\ \text { MMA } & \text { Ministério do Meio Ambiente } \\ \text { MG } & \text { Mata de Galeria } \\ \text { PAc } & \text { Precipitação acumulada } \\ \text { PPGEA } & \text { Programa de Pós-Graduação em Geografia } \\ \text { PTARH } & \text { Programa de Pós-Graduação em Tecnologia Ambiental e Recursos Hídricos } \\ \text { SE } & \text { Solo Exposto } \\ \text { UnB } & \text { Universidade de Brasília } \\ & \end{array}$




\section{INTRODUÇÃO}

É crescente a necessidade pela manutenção e preservação dos estoques de água potável no mundo. O consumo de água pela sociedade ampliou-se com a industrialização e vem aumentando a cada dia com o crescimento demográfico. Em contraste a isso, as sociedades tem procurado adaptar o uso dos recursos naturais a sua necessidade ao contrário de adequar seus hábitos de consumo aos ambientes naturais.

Sabe-se que um bom manejo do solo tem sido uma, dentre as diversas opções para melhorar a gestão dos recursos hídricos (FULLEN, 2013). Afinal, o solo tem um papel importante no uso e na reciclagem da água, ajudando a equilibrar os efeitos causados por excessos ou deficiências hídricas, já que funciona como um grande reservatório.

A cada ano, cerca de $500.000 \mathrm{~km}^{3}$ de água se evapora diretamente da superfície e da vegetação terrestres, sendo que $110.000 \mathrm{~km}^{3}$ retornam aos continentes na forma de chuva ou neve (BRADY; WEIL, 2013). A água que cai sob forma de precipitação, nos continentes, permanece na superfície do solo ou infiltra lentamente, até juntar-se às águas subterrâneas que é quem alimenta os rios, lagos e lagoas perenes para que continuem com água inclusive no período da seca.

Dessa forma, tornam-se cada vez mais complexos os impactos resultantes da ação antrópica sobre os solos, já que muitas vezes repercutem regionalmente. A erosão, por exemplo, tem efeitos off site que se devem ao escoamento de água e sedimentos que atingem áreas afastadas ou contíguas àquelas onde a erosão esteja ocorrendo (GUERRA; MENDONÇA, 2004). A erosão hídrica, ainda ocasiona a lixiviação dos nutrientes dos solos agricultáveis. Esses nutrientes são carreados em solução e, por consequência, há eutrofização dos corpos hídricos, e o assoreamento dos mesmos. Além disso, a ação humana tem contribuído fortemente para a diminuição do volume de água que infiltra no solo, a exemplo da impermeabilização do solo que dificulta que a água da chuva infiltre, recarregando o lençol freático.

A alteração da cobertura natural dos solos para os mais diversos fins altera as propriedades hidro geomorfológicas de infiltração, de escoamento superficial e de erosão. Conhecer tais propriedades é de fundamental importância para o planejamento dos mais 
diversos usos: ambiental, de recursos hídricos, urbanização, saneamento básico, agrícola, prevenção a desastres, lazer, dentre outros.

O Bioma Cerrado ainda é pouco conhecido a respeito dos processos erosivos e sua produção de sedimentos por escoamento superficial. O Cerrado ocupa cerca de $22 \%$ do território brasileiro, com uma área de $2.036 .448 \mathrm{~km}^{2}$ (MMA, 2015). O bioma está presente nos estados, principalmente, do Centro-Oeste, Mato Grosso, Mato Grosso do Sul, Goiás e Distrito Federal, além de Tocantins, Maranhão, Piauí, Rondônia, Bahia, Paraná, Minas Gerais, São Paulo, e dentro dos territórios do Roraima, Amapá e Amazonas (MMA, 2015). O Bioma Cerrado também é importante pelo fato de o seu território abrigar as nascentes das Bacias Hidrográficas do Paraná, Amazônica/Tocantins e São Francisco, as maiores da América do Sul (MMA, 2015).

As características fisiográficas do Bioma Cerrado - relevo, vegetação, solo, clima, fauna - são bastante distintas dos demais biomas brasileiros. Desta forma, é de se esperar que o volume de escoamento superficial, produção de sedimentos e infiltração, sejam distintos dos demais biomas. Grande parte dos estudos neste tema é relacionada ao Bioma Mata Atlântica (NEGREIROS; COELHO NETTO, 2009; COELHO NETTO, 1987; SATO, 2008; AVELAR, 2014; JARDIM \& FERNANDES, 2006) e Caatinga (SANTOS, 2009; SANTOS et. al, 2000; SILVA; SANTOS, 2009). Em função das condições favoráveis de topografia, tipo de terreno e facilidade de desmatamento, o Cerrado representa a principal região brasileira produtora de grãos e gado do Brasil, segundo Aguiar e Camargo (2004). Com isso, houve a remoção das áreas nativas numa escala muito acelerada, chegando a uma estimativa de que $80 \%$ da área original do Cerrado tenha sido convertida para áreas antrópicas, restando apenas $20 \%$ de áreas originais ou pouco perturbadas (MYERS et al., 2000).

O clima do Cerrado é caracterizado por duas estações bem definidas, uma seca e uma chuvosa, sendo que, durante a primeira, são registrados poucos eventos pluviométricos, e na segunda, concentram-se as chuvas, muitas vezes de alta intensidade. As precipitações convectivas têm como característica alta intensidade pluviométrica, ou seja, altura de chuva alta em um curto intervalo de tempo, e pingos maiores com maior poder erosivo (SILVA. (1984; KINNELL ${ }^{1}$ apud RIBEIRO, 2006). O período seco que antecede as chuvas também

${ }^{1}$ KINNEL, P. I. A. Splash erosion of primary particles and aggregates. Soil Science Society of America Journal, Madison, v. 40, n. 6, p. 966-968, Nov./Dec. 1976. 
provoca o ressecamento dos solos, fazendo com que as partículas possam ser mais facilmente desprendidas e transportadas com a chegada das precipitações.

Pouco se tem estudado, por meio direto, a perda de solo no Cerrado. Na Universidade Federal de Uberlândia há uma linha de pesquisa neste sentido, porém não há ênfase ao estudo neste bioma (PINESE; GARBIN; RODRIGUES, 2006).

Diante disso, é iminente que sejam feitos estudos para o conhecimento ecológico dos ambientes do Cerrado, no sentido da manutenção da biodiversidade e de um desenvolvimento agrícola e urbano mais ordenado. Conhecer, portanto, o comportamento hidro geomorfológico dos solos do Cerrado é um passo importante para sua conservação e para a elaboração de medidas que visem à mitigação de pressões antrópicas nos diversos usos do solo, no Distrito Federal.

Tem-se estudado a viabilidade de se utilizar as águas das Bacias contribuintes e do próprio Lago Paranoá com vistas ao abastecimento público, segundo informativo da CAESB (2015). Para tanto, há que se estudar a qualidade e o volume da água disponível. Os mais diversos tipos de uso na bacia podem comprometer a qualidade da água do reservatório, por contaminação e pelo assoreamento, ambos ocasionados pelo escoamento superficial que transporta sedimentos, nutrientes lixiviados e outros contaminantes.

Apesar de o Distrito Federal possuir grande parte de seu território ocupado por Unidades de Conservação, diversas dessas unidades são Áreas de Proteção Ambiental, que permitem a urbanização. Porém, a expansão urbana tem ocorrido de forma desordenada, com o aumento de condomínios irregulares que não possuem coleta de esgoto, nem tampouco sistema de drenagem de águas pluviais, gerando consequente aumento da impermeabilização do solo e do escoamento superficial, segundo trabalho elaborado por Menezes (2010).

No presente trabalho, a área de estudo é a Bacia do Ribeirão do Gama que é contribuinte do Lago Paranoá, localizada na região Sul-Sudoeste do Distrito Federal, que compreende uma área de $147 \mathrm{~km}^{2}$. Juntamente com a bacia Cabeça de Veado, compõem uma Área de Proteção Ambiental de 25mil ha, que abrangem as Regiões Administrativas de Brasília (1\%), Núcleo Bandeirante (22\%), Santa Maria (9\%), Lago Sul (65\%) e Candangolândia (3\%).

O Laboratório de Geografia Física, do Departamento de Geografia, da Universidade de Brasília, está desenvolvendo estudos hidro erosivos na bacia do Gama, no âmbito do grupo 
"Estudos Hidrológicos e Hidráulicos" junto à Engenharia Civil e Geociências da UnB, e em cooperação com a Agência Nacional de Águas. Os estudos estão voltados a processos hidrológicos e erosivos nas bacias do DF, com o objetivo de verificar como esses processos estão ocorrendo e quais são suas repercussões no Lago Paranoá.

No Distrito Federal, têm sido realizadas pesquisas indiretas de estimativas de produção de sedimentos e estudo do escoamento superficial relacionado com a precipitação em uma micro bacia hidrográfica a partir do aumento da vazão do rio, considerando as variáveis Precipitação, Precipitação Antecedente e a Intensidade da Precipitação (ALENCAR; SILVA; OLIVEIRA, 2006). Também foi calculada a estimativa das cargas de sedimentos e nutrientes lançando mão do Modelo SWAT (Soil and Water assessment Tool), com o objetivo de comparar dados observados e calculados (MINOTI; KOIDE; LIPORINI, 2011). Porém, ainda não foram realizadas pesquisas de medição direta da perda de sedimentos. O presente trabalho vislumbra preencher essa lacuna, visando gerar dados diretos de perda de sedimentos via erosão hídrica, oferecendo dados para o melhoramento de estimativas via modelagem.

\subsection{CARACTERIZAÇÃO DA ÁREA DE ESTUDO}

A área de estudo é a bacia hidrográfica do Ribeirão Gama (Figura 1.1), localizada na região sul do Distrito Federal, Brasil, entre as coordenadas de $15^{\circ} 50^{\prime}$ e $16^{\circ}$ de latitude sul e $47^{\circ} 50^{\prime}$ e $48^{\circ}$ de longitude oeste, com uma área aproximada de $137 \mathrm{Km}^{2}$ (CARVALHO et al., 2001). O Ribeirão do Gama nasce na Mata do Catetinho e recebe as águas dos Córregos do Mato Seco e Cedro, afluentes da sua margem esquerda, e dos Córregos Taquara e Capetinga, afluentes da margem direita, desaguando no Lago Paranoá com uma vazão média de $1,85 \mathrm{~m}^{3} / \mathrm{s}$ (MOURA, et al., 2010).

A escolha dessa bacia deveu-se pela existência de vegetação do Bioma Cerrado preservada e de diversos tipos de uso na área como unidades de conservação (APA Gama cabeça de Veado, Reserva Ecológica do IBGE, Estação Experimental da UnB - a Fazenda Água Limpa, e Estação Ecológica do Jardim Botânico de Brasília, Áreas de Relevante Interesse Ecológico do Bosque e Capetinga-Taquara), áreas urbanizadas (as regiões administrativas Park Way, Núcleo Bandeirante e Lago Sul, com diferentes graus de consolidação urbana) e áreas agrícolas (Núcleo Rural Vargem Bonita e Núcleo Rural Córrego Onça) (UNESCO, 2003; CARVALHO et al., 2001). 

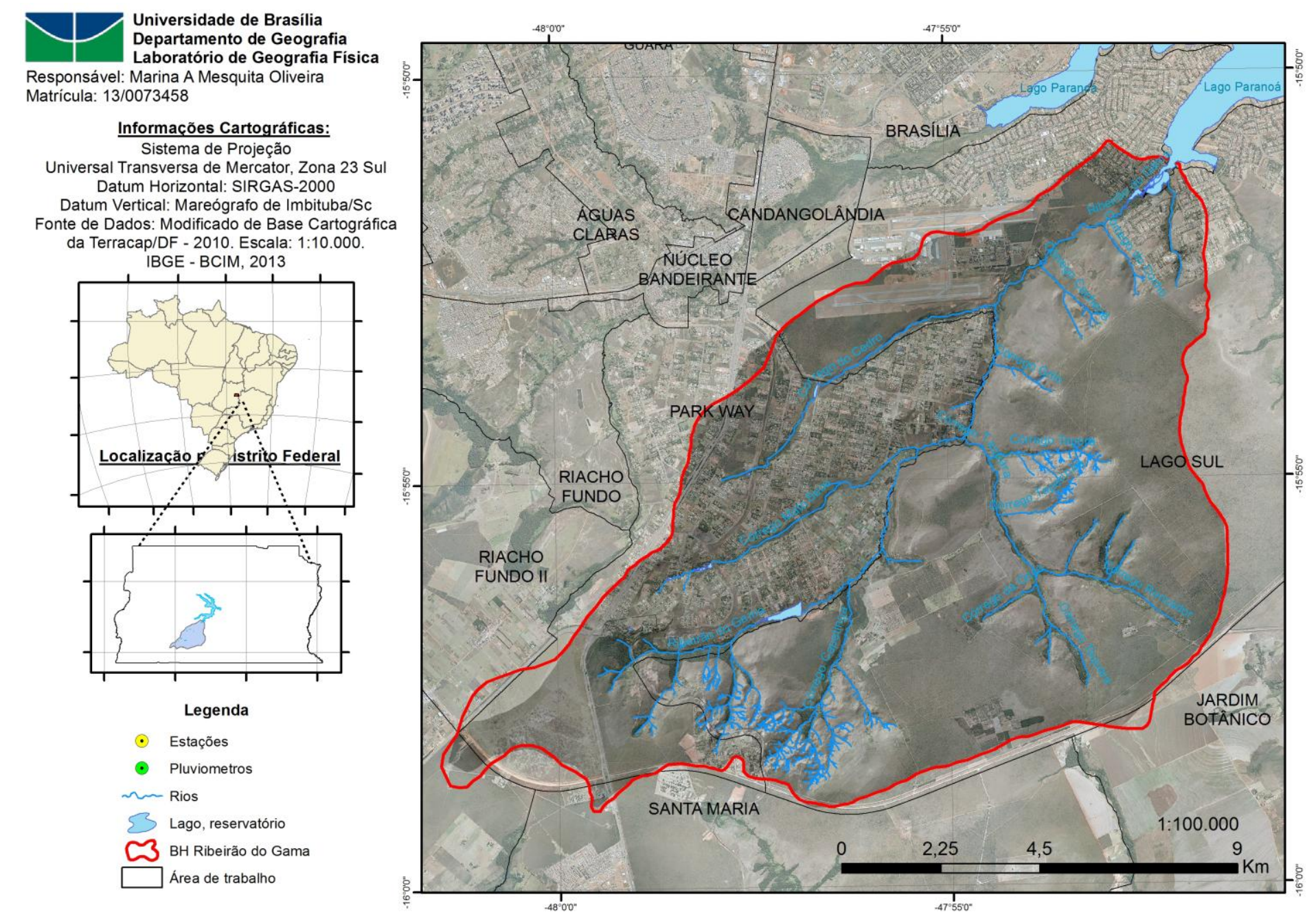

Figura 1.1 - Localização da Bacia Hidrográfica do Ribeirão do Gama.

Fonte: Modificado de TERRACAP/DF (2010), elaborado pela autora. 


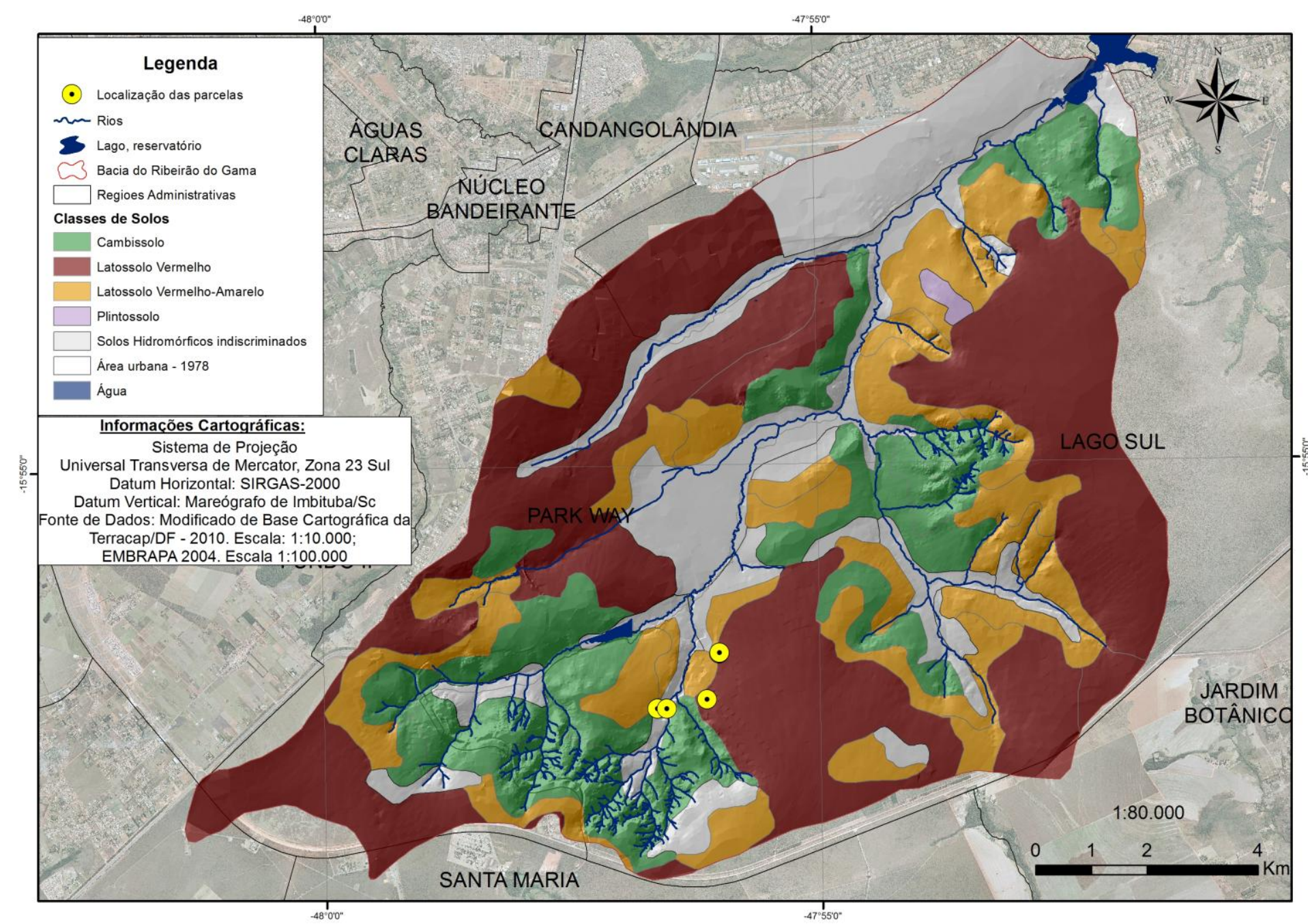

Figura 1.2 - Distribuição de classes de solo - Bacia do Ribeirão do Gama/DF.

Fonte: modificado de Embrapa (2004), elaborado pela autora. 


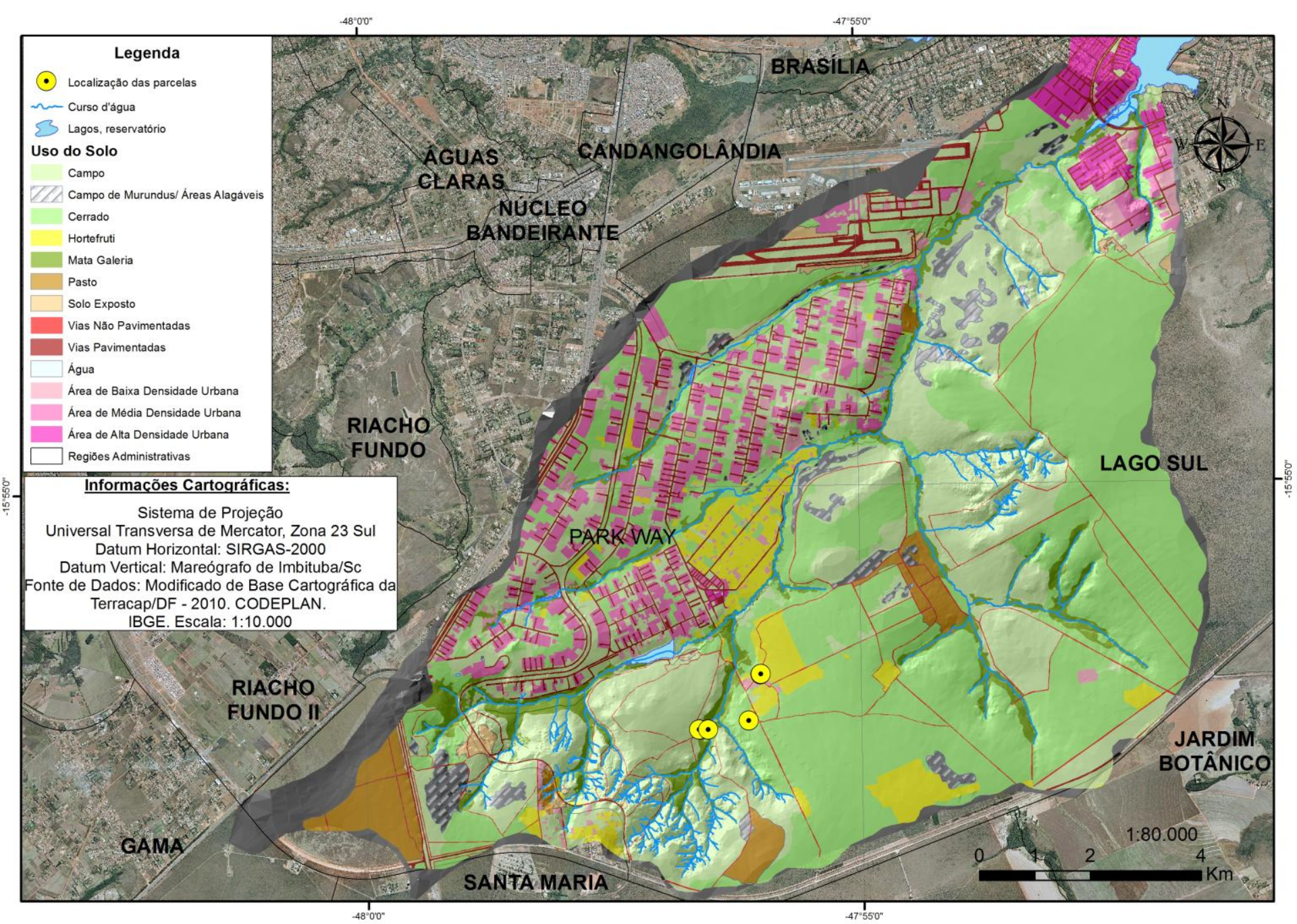

Figura 1.3 - Distribuição dos tipos e classes de uso do solo - Bacia do Ribeirão do Gama/DF.

Fonte: Modificado de TERRACAP/DF (2010), elaborado pela autora. 


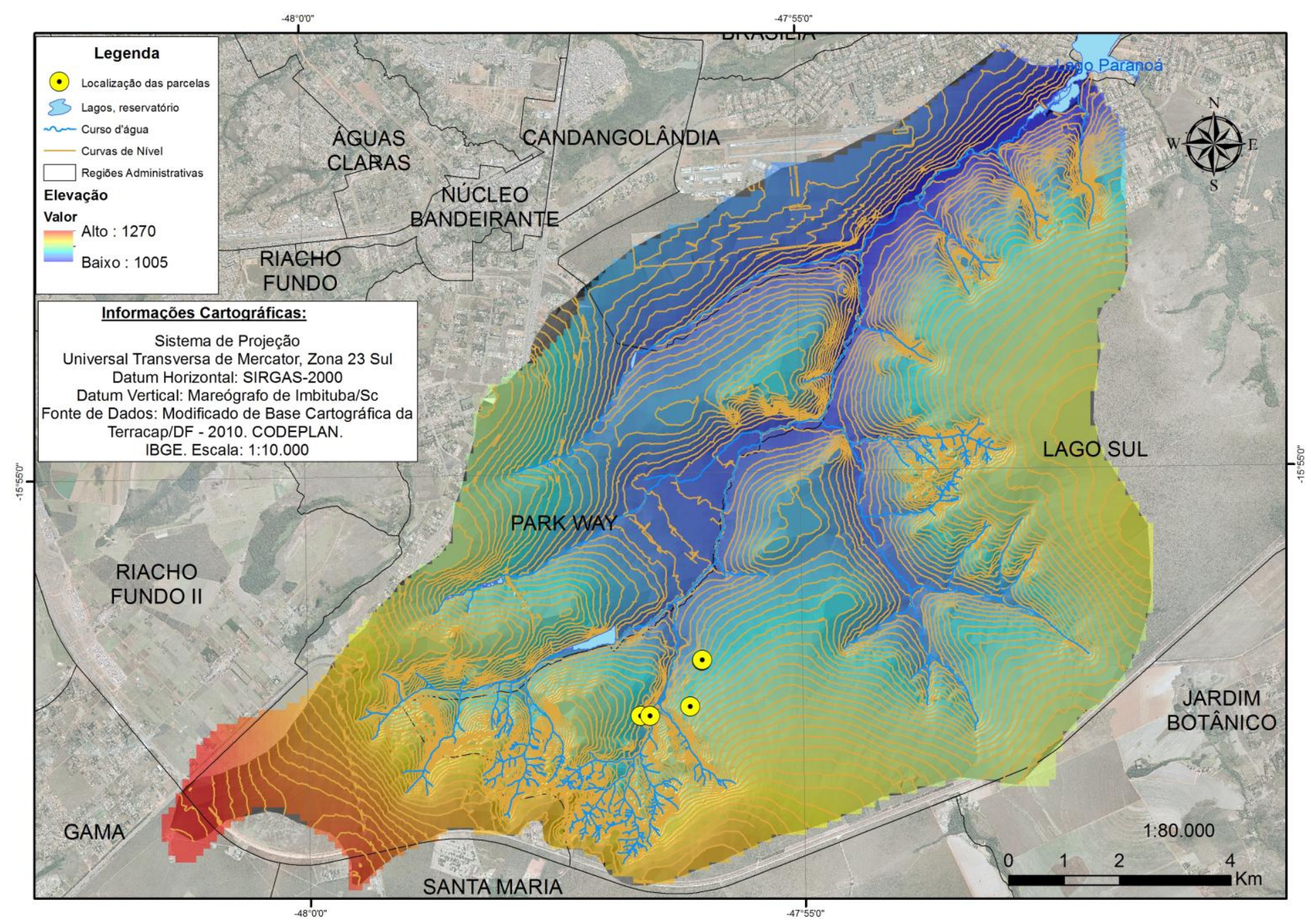

Figura 1.4 - Hipsometria da Bacia do Ribeirão do Gama/DF.

Fonte: modificado de TERRACAP/DF (2010), elaborado pela autora. 
A Bacia Hidrográfica do Ribeirão do Gama localiza-se na porção sul do Distrito Federal (Figura 1.1) e conserva, em sua área, bons exemplares de fitofisionomias do cerrado, tais como Cerrado Típico, Campo Sujo, Campo Limpo, Campo Rupestre, Campos de Murundus, Vereda, Mata Mesofítica e Cerradão (Figura 1.3).

As fitofisionomias deste bioma diferem entre si pelos exemplares de flora e fauna (árvores, arbustos, gramíneas, trepadeiras, etc.), pela formação ou não de dossel e extrato vegetacional, com a proximidade ou distância de corpos hídricos, tipo e profundidade do solo, altitude, geologia, etc.

A bacia do Ribeirão do Gama é composta por dois compartimentos geomorfológicos. A Depressão do Paranoá é caracterizada com inclinações e dissecações vindo do alto das Chapadas da Contagem e de Brasília, indo em direção aos vales, com declividades variando entre $20 \%$ próximo ao lago e a $50 \%$, próximo a transição para as chapadas elevadas, constituindo escarpa. Ao sul e sudoeste da bacia estão áreas localizadas nas chapadas tendo o relevo plano com suaves ondulações com declividades de 10\% a 20\% (Figura 1.4) (PINTO, 1990).

Nas áreas de relevo plano a suavemente ondulado, a densidade de drenagem é baixa em função da menor dissecação, onde predominam os Latossolos. Por outro lado, as bordas das chapadas apresentam dissecação pronunciada, o que caracteriza uma situação de instabilidade devido à baixa relação pedogênese e erosão dos solos (RESENDE et al., 1995). Conforme destacado por Carvalho et al. (2001), em decorrência do uso da terra a erosão tende a assumir maiores proporções, o que demonstra a necessidade de controle efetivo das bacias dessa área (Figura 1.2).

A maior parte da área da bacia é recoberta pela cobertura detrítica terciáriaquaternária, a qual constitui uma superfície de erosão aplainada. Em termos lito estratigráfico, essa a área é caracterizada pela presença de rochas do Grupo Paranoá (Idade Meso /Neoproterozóica) especificamente pelas unidades Ardósia (porção Sudoeste) e Metarritmito Arenoso (porção noroeste) e por uma pequena parte composta por Quartzito médio nos topos, onde há profundos latossolos (MOURA, et al., 2010). É possível observar as diferenças no padrão das drenagens condicionadas pela litologia das duas unidades na área de estudo. Enquanto na Ardósia, com solos mais argilosos a drenagem pouco se desenvolveu, pode-se observar que na borda das chapadas há uma drenagem detrítica se desenvolvendo com o aprofundamento do nível de base do Córrego do Gama. 
Como pode ser visto na Figura 1.2, de forma geral, a região da bacia do Gama apresenta predomínio da classe pedológica dos Latossolos Vermelhos e Vermelho-Amarelo. Os Latossolos Vermelhos normalmente localizam-se em áreas mais elevadas, tal como as chapadas, já os Latossolos Vermelho-Amarelos são mais facilmente encontrados próximo as bordas das chapadas, onde os solos sofrem alto grau de intemperismo e lixiviação, refletem o amplo predomínio de goethita em relação à hematita, apresentando teores de $\mathrm{Fe} 2 \mathrm{O} 3$ entre 7 e 11\%, quando de textura argilosa ou muito argilosa (EMBRAPA-SNLCS, 2009).

A outra classe de solo encontrada nesta localidade é o Cambissolo. Essa compreende os solos pouco desenvolvidos e muitas vezes cascalhentos, pedregosos e rochosos, que estão relacionados às bordas das chapadas propriamente ditas e às áreas de encostas. Nas bordas também há localização de fragmentos de lateritas, confirmando as teorias de evolução de relevo contidas no documento "evolução geomorfológica do Distrito Federal” (MARTINS et. al, 2004). E, nas proximidades dos cursos d'água predominam os Gleissolos, associados às áreas de surgência de água, com relevo plano e suave ondulado. Nessas áreas também é comum encontrar antigos depósitos fluviais abandonados com presença de fácies argilosos, arenosas e cascalhentas.

O clima da região caracteriza-se por apresentar duas estações bem definidas: verões úmidos, entre os meses de outubro a abril, quando há a intensificação dos índices pluviométricos e com umidade relativa do ar em torno de 75\%; e inverno seco, entre os meses de maio a setembro. De acordo com a classificação de Köppen observam-se na região os tipos climáticos: tropical úmido de savana com inverno seco (Aw), cujas temperaturas médias são superiores a $18^{\circ} \mathrm{C}$ em todos os meses do ano e ocorre nas áreas abaixo de 1.000 metros; além dos tropicais de altitude ( $\mathrm{Cwa}, \mathrm{Cwb})$ que ocorrem nas porções mais elevadas, como no Pediplano de Brasília.

O regime pluviométrico caracteriza-se por precipitações mal distribuídas durante o ano. A média anual é de aproximadamente $1.600 \mathrm{~mm}$, sendo que o mês de janeiro pode apresentar índices de $320 \mathrm{~mm} / \mathrm{mês}$, enquanto que nos meses de junho a agosto as médias não ultrapassam os $55 \mathrm{~mm}$. Em relação à vazão, estudos recentes relacionados ao grupo de pesquisa (SOUZA et al, prelo) indicam que a Bacia do Gama contribui com a Bacia do Paranoá com vazões médias na ordem de $0,45 \mathrm{~m}^{3} / \mathrm{s}$ à $5,0 \mathrm{~m}^{3} / \mathrm{s}$ e cargas sólidas médias na ordem de 7,0 à 5500 ton./dia; 


\subsection{OBJETIVOS}

\section{Objetivo Geral:}

Este trabalho tem como objetivo conhecer o comportamento hidro erosivo dos solos em cinco diferentes tipos de uso e cobertura da terra, mensurando os volumes de escoamento superficial e produção sedimentar no Bioma Cerrado, além da correlação destes valores e a tensão da água no solo, tendo como estudo de caso a Bacia do Ribeirão do Gama.

\section{Objetivos específicos:}

- Estudar as propriedades granulométricas do solo, inferindo a erodibilidade para cada situação em estudo;

- Estudar o regime hídrico via mensuração direta da precipitação, inferindo a erosividade das chuvas.

- Verificar a correlação entre sucção do solo e escoamento superficial;

- Estudar o escoamento superficial e perda de solos via mensuração direta em parcelas hidro-erosivas.

\subsection{ESTRUTURA DO TRABALHO}

A presente dissertação é organizada conforme regulamento do Programa de PósGraduação em Geografia, e se inicia com a Introdução, onde se apresenta o tema do trabalho, bem como a sua justificativa, recorte espacial da análise, objetivos geral e específicos.

O Capítulo 2 trata-se do Referencial Teórico geral do trabalho, onde são apresentadas as bases conceituais que foram utilizadas, visando conhecer melhor o objeto de estudo, tais como o Ciclo hidrológico e bacias hidrográficas, hidrogeomorfologia e seus processos.

O Capítulo 3 é a Metodologia Estendida, onde são descritos todos os materiais e métodos utilizados no trabalho. Neste capítulo, a metodologia é apresenta de forma pormenorizada, em apoio ao capítulo 4.

No Capitulo 4 são apresentados os resultados da presente dissertação. Este capítulo foi organizado em formato de artigo sob o título de "Mensuração de perdas de sedimentos por escoamento em diferentes usos e coberturas da terra no Bioma Cerrado: Bacia Hidrográfica do Ribeirão do Gama/DF", contendo introdução, materiais e métodos, resultados e discussões e referências bibliográficas. Pretende-se submeter o artigo à Revista 
Brasileira de Hidrologia e Recursos Hídricos. O capítulo 2 e o capítulo 3 são mais densos com objetivo de dar apoio teórico e metodológico ao artigo. As referências bibliográficas estão em tópico único não numerado, não tendo sido ainda individualizadas entre artigo e o restante da dissertação. 


\section{REFERENCIAL TEÓRICO}

\subsection{CICLO HIDROLÓGICO E HIDROGEOMORFOLOGIA}

A distribuição da água no planeta é claramente desigual, tanto do ponto de vista do espaço, quanto do tempo. A divisão da Terra em zonas climáticas é um exemplo disso, onde índices de precipitação e umidade formam um grande contraste entre zonas equatoriais e desérticas. O Brasil, por sua abrangência territorial, demonstra essa não uniformidade facilmente, como é o caso dos extremos de chuva na Amazônia e seca no Nordeste (Conjuntura dos Recursos Hídricos no Brasil, 2013). O Distrito Federal por sua vez exemplifica uma distribuição desigual de água quanto ao tempo, haja vista a sazonalidade das chuvas nessa região, quando em junho, julho e agosto a média mensal é de apenas $50 \mathrm{~mm}$, e o mês de janeiro pode alcançar $320 \mathrm{~mm}$ (SILVA et al, 2008).

Há diversas fontes de água na Terra, sendo que a maior parte está nos oceanos, geleiras e águas subterrâneas profundas. A energia solar impulsiona a ciclagem da água da superfície terrestre para a atmosfera e seu retorno para a superfície, de acordo com um conjunto de processos denominado ciclo hidrológico (BRADY; WEIL, 2013).

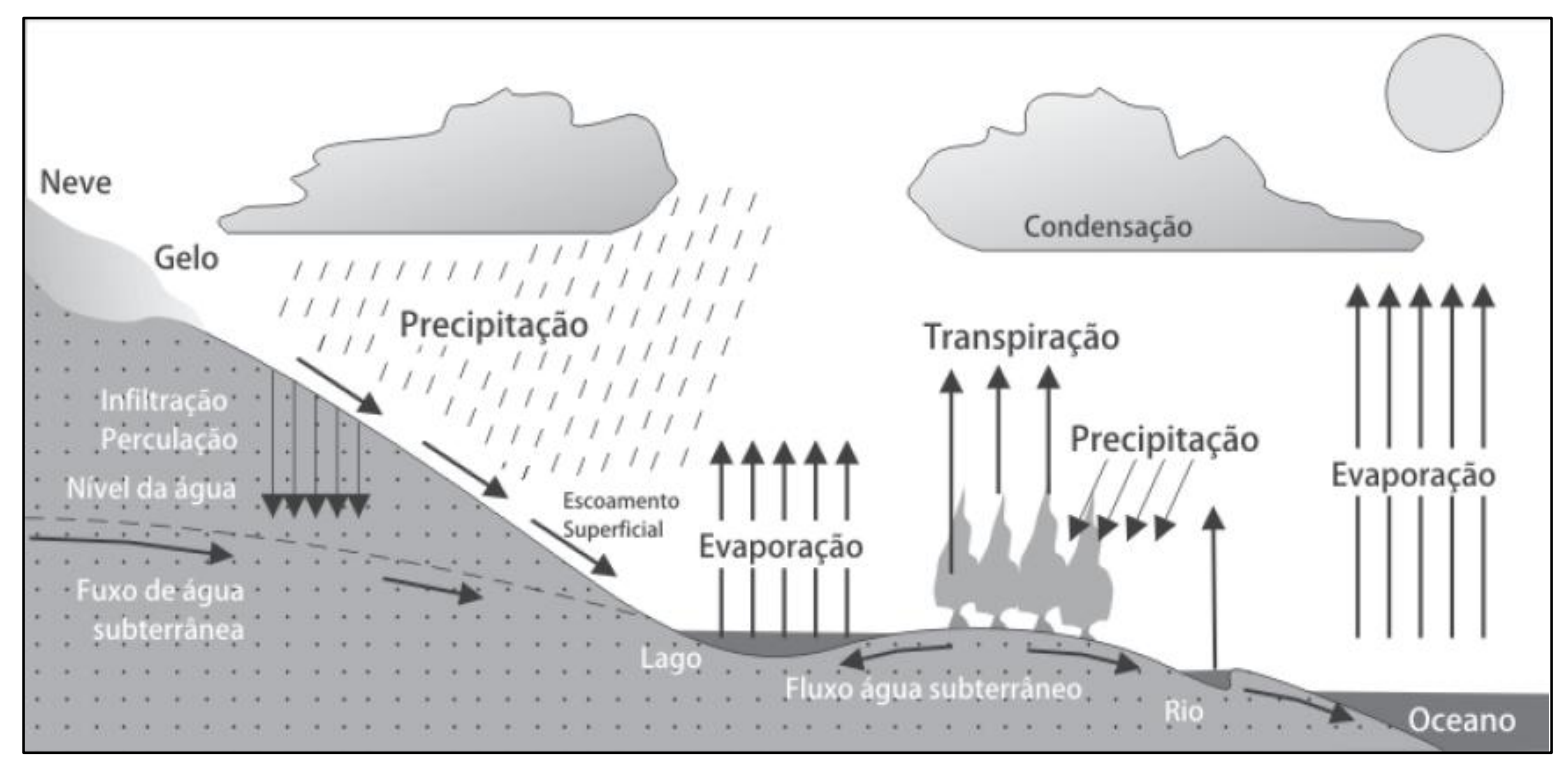

Figura 2.1 - Ciclo hidrológico.

Fonte: IGPB ${ }^{2}$ apud TUCCI e MENDES, 2006.

\footnotetext{
2 IGBP, 1993. Biosphere Aspects of the Hydrological Cycle. The International Geosphere-Biosphere Programme: A Study of Global Change, Report n.27. Estocolmo, 103p.
} 
O ciclo hidrológico representa o movimento da água no planeta que se inicia pela precipitação da água nas diversas formas (chuva, neve, granizo) em um movimento de cima para baixo. Enquanto ocorre a precipitação, a água pode tomar diversos caminhos, entre ser evaporada antes mesmo de tocar o solo ou alguma planta; ser interceptada pela vegetação; infiltrar a terra; escoar superficialmente; compor lagos, rios e oceanos, e novamente ser evaporada, retornando à atmosfera, ficando disponível à nova precipitação (Erro! Fonte de referência não encontrada.).

Segundo Brady e Weil (2013), o valor correspondente de evaporação direta da superfície terrestre e vegetação, por ano, é cerca de $500.000 \mathrm{~km}^{3}$, sendo que o que retorna às terras emersas em forma de chuva ou neve é de $110.000 \mathrm{~km}^{3}$. O autor inteira, ainda, que o movimento líquido de nuvens traz perto de $40.000 \mathrm{~km}^{3}$ de água para os continentes, que igualmente retorna por escoamento superficial ou infiltração e depois é canalizada através dos rios, para os oceanos.

O ciclo hidrológico acontece no espaço e no tempo, e uma das principais unidades territoriais onde ocorre, são as bacias hidrográficas. As bacias hidrográficas são unidades geomorfológicas nas quais são drenados água, sedimentos e detritos em um canal fluvial comum, ou seja, toda a precipitação de cai sobre ela e todos os sedimentos transportados irão se dirigir por efeito da gravidade para o ponto mais baixo do relevo, sendo este a foz. As bacias hidrográficas são delimitadas pelos seus divisores de água, sendo estes os pontos mais altos do relevo (COELHO NETTO, 2003). As perturbações ocorridas em um desses componentes podem ser sentidos nos demais, alterando o equilíbrio do sistema (teoria dos sistemas de CHORLEY, 1962).

Quando se fala em bacia hidrográfica, há de se considerar a distribuição de água por seus divisores, que pode ser expressa pela Equação do Balanço Hídrico (2.1):

$$
\mathrm{Q}=\mathrm{P}-\mathrm{ET}-\mathrm{AS}
$$

onde $P=$ precipitação, ET= evapotranspiração, $A S=$ armazenamento no solo $e$ $Q=$ vazão da descarga.

A equação expressa acima tem formato simplificado, mas serve de exemplo para entender como estas variáveis podem ser modificadas de forma que se atendam as necessidades de alteração ou organização das práticas dentro de uma bacia hidrográfica, principalmente no que se refere à disponibilidade hídrica. Um relatório do Center of 
Watersheds Protection (2011) sobre conservação das florestas e proteção de água potável exemplifica que para uma bacia hidrográfica florestada, o manejo pode visar maximizar a vazão da descarga $(Q)$, a fim de fornecer mais água a jusante para os que a usam e que o desmatamento em certas porções da área de captação muito provavelmente diminuirá a evapotranspiração $(E T)$ e, portanto, aumentará a vazão de descarga $(Q)$.

A precipitação total é a soma dos valores de chuva do período que se quer avaliar (hora, dia, semana, mês, ano). Estes valores não são estáticos e variam ao longo do tempo. Para que seja possível uma avaliação dos aspectos de precipitação de uma área de estudo, são necessários dados de aos menos 10 anos consecutivos. Já a distribuição sazonal é o comportamento da chuva ao longo do ano. Nos trópicos, as chuvas concentram-se mais, geralmente, durante os meses de setembro a março, diminuindo significativamente sua ocorrência nos demais meses do ano. A intensidade é o volume precipitado em função do tempo. Chuvas intensas têm um maior poder erosivo, do que as menos intensas (CREPANI et al., 2001; GUERRA, 2010).

A capacidade da chuva em causar erosão é denominada erosividade em função de suas características físicas. O tamanho da gota de chuva e a energia cinética com que toca a superfície mineral do solo são as características da precipitação que tem maior poder erosivo. É uma relação entra a quantidade de massa e a força exercendo pressão sobre o solo. Essas características estão relacionadas com a intensidade da chuva (JÚNIOR et al., 2009).

Como pode ser observado na Figura 2.2, a interceptação da água chuva é sua captura pela vegetação, antes que chegue ao solo. Segundo Horton ${ }^{3}$ apud Chorley (1980), tanto a possiblidade de ocorrência, quanto o seu valor dependem das espécies vegetais e da sua densidade. A partir do primeiro $1 \mathrm{~mm}$ de uma chuva, cerca de $20 \%$ do restante seriam interceptados, preenchendo suas irregularidades, até que começassem a escorrer pelos galhos e troncos (fluxo de tronco - stemflow). Desse montante entre 1 e $5 \%$, seriam perdidos por evapotranspiração, restando em torno de $74 \%$ que iriam atravessar a cobertura vegetacional e cair sobre a superfície, cerca e $75 \%$, constituindo a precipitação terminal (HORTON apud CHORLEY, 1980).

\footnotetext{
${ }^{3}$ HORTON, R. E. Rainfall interception. Monthly Wather Review, vol. 47, p. 603-623, 1919.
} 


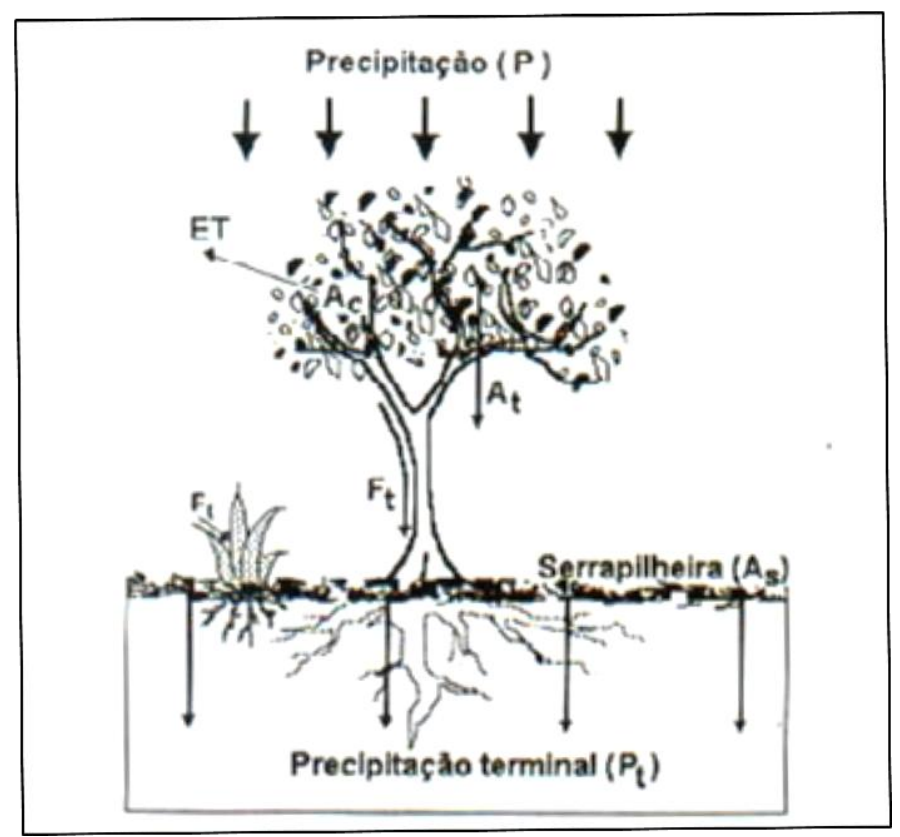

Figura 2.2 - Componentes da interceptação: P é a precipitação; ET é a evapotranspiração; A é o armazenamento nas copas; At é o atravessamento nas copas; e F, é o fluxo de tronco.

Fonte: Coelho Netto. 2003.

Parte da precipitação que toca as copas é evaporada durante e depois da chuva, não fazendo parte, posteriormente, da vazão dos rios (TRICART, 1977; COELHO NETTO, 2003; NASCIMENTO, 1992), o que garante certo grau de umidade no ar, diminuindo a transpiração das plantas. A vaporização das águas do solo, somadas à água que é transpirada pelos estômatos das superfícies das folhas das plantas retornam também para a atmosfera, e é o que chamamos de evapotranspiração.

Quando a precipitação chega ao solo, ocorre a infiltração, que é a absorção dessa água pela superfície. A capacidade de infiltração depende da permeabilidade do solo, não somente do primeiro horizonte, mas também do horizonte abaixo deste (BAVER ${ }^{4}$ apud CHORLEY, 1980). A porosidade do solo está diretamente ligada com a capacidade de infiltração. Os microporos existentes no solo exercem uma força de capilaridade alta sobre a água, dificultando seu fluxo no perfil, enquanto que os macroporos permitem que a água infiltre mais facilmente (DUNNE; LEOPOLD, 1978). A variação da infiltração no tempo ocorre durante a precipitação, onde há um declínio da capacidade de infiltração do solo, sendo resultado de leis físicas que governam o fluxo da água dentro do solo (BODMAN;

${ }^{4}$ BAVER, L. D. Colloidal properties of soil organic matter (Research bulletin / University of Missouri, Agricultural Experiment Station) Unknown Binding - 1937. 
COLMAN $^{5}$ apud CHORLEY, 1980). A água é retida em depressões na superfície, podendo ser evaporada ou infiltrada.

Quando a água infiltra próximo ao divisor da bacia hidrográfica pode escoar ou percolar em um movimento vertical em direção ao lençol freático, ou subsuperficialmente. Este segundo fluxo está sujeito, principalmente, à força da gravidade que faz com que a água faça o movimento descendente; e à pressão potencial que corresponde à força com que os grãos do solo retêm a água, causando um movimento vertical ascendente, ou lateral (ATKINSON, 1980; BRADY; WEIL, 2013). No segundo caso. O fluxo ocorre pelas diferenças do potencial matricial da água no solo, onde a água tende a se mover de um ponto de maior energia (maior umidade) em direção ao ponto de menor energia (menor umidade) (ATKINSON, 1980; BRADY; WEIL, 2013). O fluxo subsuperficial pode ocorrer no contato entre a rocha ou um horizonte de solo impermeável, e o horizonte acima deste permeável; ou através de pipes (tubos), cuja origem são as galerias feitas por microorganismos e por raízes, formando um lugar de fluxo preferencial da água (ATKINSON, 1980).

No caso do escoamento superficial existem dois tipos principais reconhecidos na bibliografia (Figura 5): o escoamento superficial Hortoniano, que é gerado quando a precipitação excede a capacidade de infiltração do solo e o escoamento superficial sob solos saturados (HORTON, 1934; BRUIJNZEEL ${ }^{6}$ apud TUCCI; MENDES, 2006).

Quando a precipitação excede a capacidade de infiltração do solo, a chuva passa a preencher as irregularidades da superfície (depression storage - este volume ou será infiltrado ou evaporado), até que estas também tenham sua capacidade de retenção excedida. Dá-se início a um pequeno fluxo que corre por sulcos e ravinas (fluxo preferencial), podendo ocorrer a junção deste fluxos formando um fluxo laminar, ou em lençol, sendo este o escoamento superficial (DUNNE; LEOPOLD, 1978; CHORLEY, 1980).

O escoamento superficial movimenta-se em direção aos fundos de vales por força da gravidade, e sua velocidade e volume são influenciados pelos elementos da superfície do solo, tanto de suas características, quanto por sua cobertura e uso, e seu incremento pode acarretar em muitos prejuízos (DUNNE; LEOPOLD, 1978). O escoamento superficial chegará a um

${ }^{5}$ BODMAN, G. B.; COLEMAN, E. A. Moisture and energy during downward entry of water into soils. Proc. Soil Sci. Soc. Of America, vol. 7, p. 116-122, 1943.

${ }^{6}$ BRUIJNZEEL, L.A., 1990. Hydrology of Moist Tropical Forests and Effects of Conversion: A State of Knowledge Review. IHP. IAHS. UNESCO.224p. 
canal fluvial, onde está estará disponível para a evaporação e consequente precipitação, completando as fases do ciclo hidrológico.

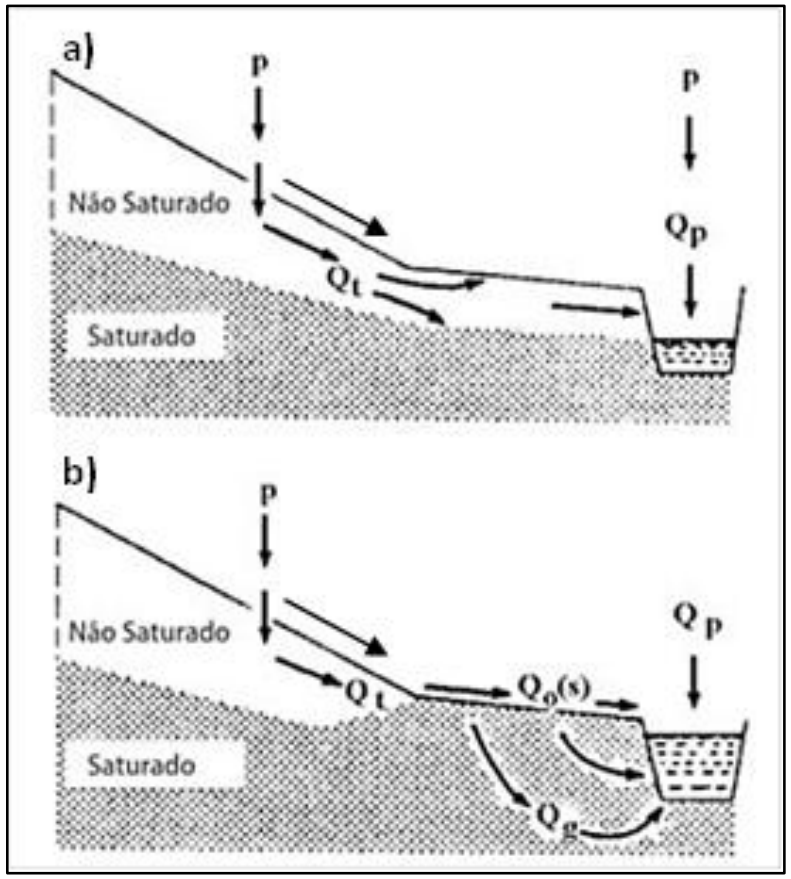

Figura 2.3 - a) escoamento superficial hortoniano (HORTON, 1934) e escoamento superficial em áreas de saturação .

Fonte: BRUIJNZEEL apud TUCCI e MENDES, 2006.

Segundo Goerl; Kobiyama e Santos. (2012), Scheidegger ${ }^{7}$ conceituou a hidrogeomorfologia como sendo o estudo da evolução das formas do relevo devido a ação das águas. A hidrogeomorfologia incorpora conceitos e métodos, tanto da geomorfologia, quanto da hidrologia. Estuda a interação entre o sistema de encostas e o sistema fluvial, e como a forma do relevo influencia os processos hidrológicos, e os segundos, depois de modificados, modificam o primeiro (OKUNISHI, 1991, 1994).

${ }^{7}$ SCHEIDEGGER, A. E. Hydrogeomorphology. Journal of Hydrology, n. 20, p. 193-215, 1973 


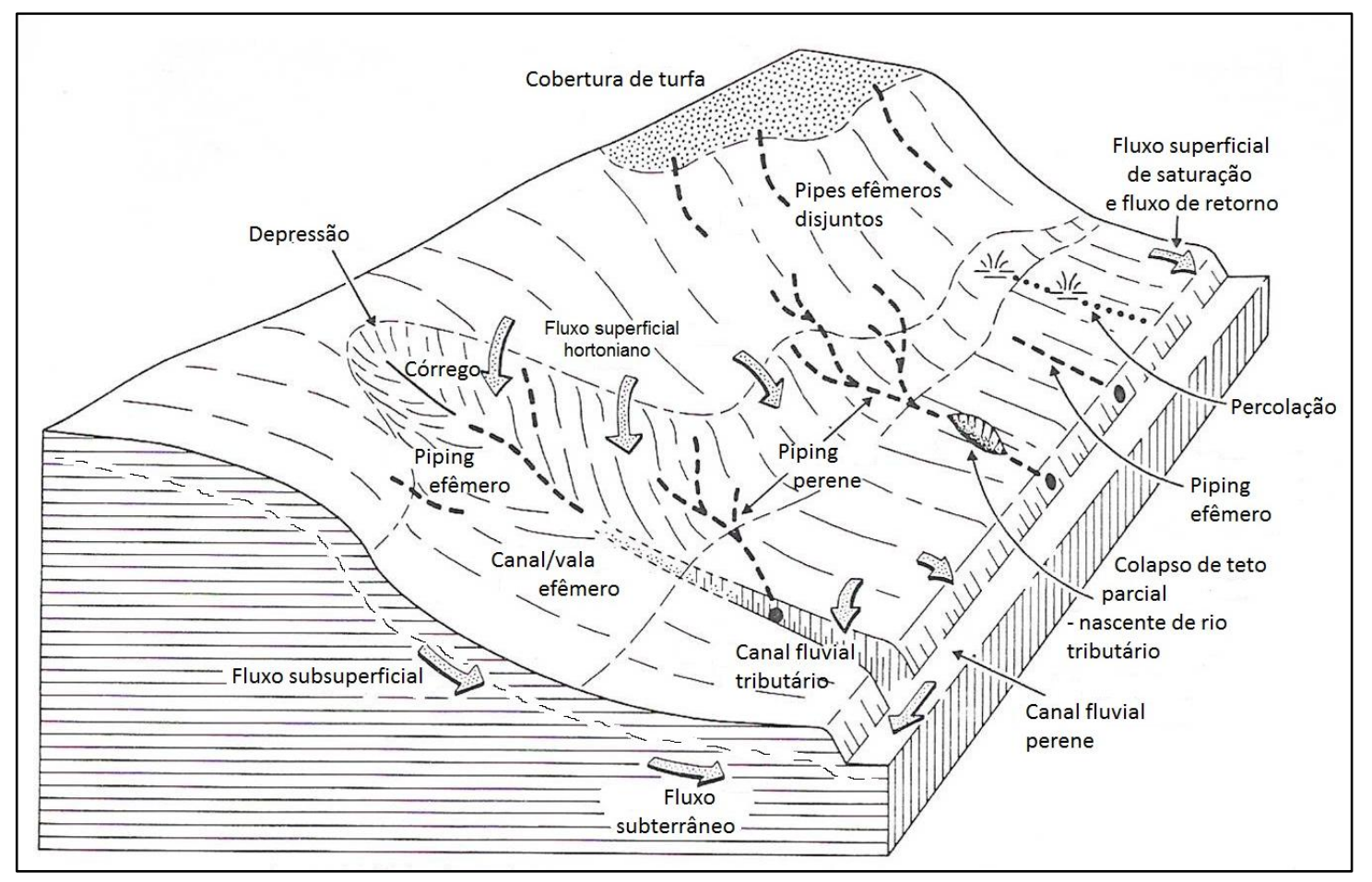

Figura 2.4 - Exemplos de processos erosivos condicionados por diferentes fluxos hídricos

A Figura 2.4 representa uma encosta com seus principais elementos. Os processos hidrogeomorfológicos que ocorrem nas encostas, em grande parte ocasionados pela precipitação em forma de chuva ou neve, são o intemperismo, o transporte e a deposição de sedimentos.

Em relação ao escoamento superficial, segundo Guerra (2003), podem ser considerados dois tipos de processos erosivos: erosão laminar ou difusa, que causa o transporte superficial difuso; e, erosão concentrada em canais, que pode causar sulcos e ravinas. O escoamento subsuperficial e o subterrâneo ao causarem a formação dos pipes, podem também fazer com que o solo que cobre o túnel formado colapse, dando origem a uma voçoroca. A água e os detritos carreados serão drenados em direção a jusante para o canal de saída da bacia.

Se o solo tiver alguma cobertura, tal como gramínea ou serapilheira, os pingos da chuva não cairão diretamente sobre o solo, assim evitando o salpicamento, ou efeito splash (GUERRA, 2003), sendo este o desprendimento e lançamento de partículas do solo decorrentes da força cinética das gotas de água que atingem a superfície livre. A gramínea e a 
serapilheira tem o papel de amortecer a queda dos pingos de água, além de absorver parte da humidade recebida, e evitar o ressecamento do solo.

As raízes das plantas também exercem um papel fundamental neste processo areando o solo com as galerias formadas, permitindo que a água infiltre; ajudam a manter as partículas do solo agregadas, dificultando o transporte de sedimentos. A capacidade de infiltração do solo depende de sua composição, da maneira como as partículas estão agregadas, de sua granulometria, tamanho dos poros, teor de matéria orgânica nos agregados e da quantidade de água já existente no solo em determinado momento (AVELAR; COELHO NETTO, 1996).

\subsection{MENSURAÇÃO HIDROLÓGICA E DA PERDA DE SEDIMENTOS}

A mensuração real volume de escoamento superficial, infiltração e de erosão, dentro do contexto de uma bacia hidrográfica, fornecem dados a respeito da dinâmica hidrológica local, e devem ser estudados levando em consideração determinados controles, tais como a litologia, a estrutura e mergulho das camadas, a forma do relevo (côncavo, convexo e plano), comprimento da rampa, ausência ou presença de cobertura (tipo, altura, com ou sem dossel, com ou sem estratos), regime climático. Todos esses elementos influenciam tanto na produção de sedimentos, quanto em seu transporte, velocidade e distância de transporte e na deposição, seja na encosta (colúvio), seja no canal fluvial.

A mensuração do escoamento superficial pode ser realizada indiretamente por meio do aumento da vazão de uma determinada bacia. Alencar, Silva e Oliveira (2006), ao estudar a influência da precipitação da microbacia do Córrego Capetinga (subbacia do Ribeirão do Gama), estudou seis anos hidrológicos (1996 a 2002), e avaliou todos os eventos

pluviométricos que provocaram escoamento superficial maior $0,1 \mathrm{~mm}$. Para tanto, obteve-se as hidrógrafas de tais eventos pluviométricos através da curva-chave da estação existente na época, e assim separou-se o escoamento superficial do escoamento de base. As variáveisexplicativas Precipitação (P), Intensidade da Precipitação (IP) e Precipitação Antecedente (PA) foram examinadas com o objetivo de verificar qual a contribuição de cada uma para a formação do escoamento superficial da microbacia em estudo.

Observou-se que a variável Precipitação, sozinha, não contribuía significativamente para a produção de escoamento superficial. Porém, ao ser avaliada associada às demais 
variáveis, a variável-resposta tinha valor maior. Das três variáveis-explicativas examinadas, a Intensidade da Precipitação mostrou maior influência na geração do escoamento superficial do que PA, tanto em seu efeito aditivo, quanto na sua interação com as demais variáveis (IPxP, IPxPA e IPxPAxP), e na interação Precipitação Acumulada e Precipitação (PAxP) O estudo também apontou para boas condições de infiltração da microbacia, com um coeficiente de escoamento superficial de 0,36 (ALENCAR; SILVA; OLIVEIRA, 2006).

A mensuração das variáveis em questão - a perda de sedimentos por escoamento superficial e o escoamento superficial- de uma encosta pode ser realizada diretamente por meio de parcelas hidro-erosiva, também conhecida por parcela de erosão. As parcelas de erosão começaram a ser usadas no âmbito do Departamento de Agricultura dos Estados Unidos (USDA, sigla em inglês) com o objetivo de medir as perdas de solo usados na agricultura, avaliando os tipos de solo, a perda de fertilidade, a entrada de água no sistema por meio da precipitação, a infiltração, os cultivos agrícolas e o escoamento superficial. Diversos modelos e tamanhos foram testados, tais como de Wishmeier $\left(25 \times 4 \mathrm{~m}^{2}\right)$, ou de Gerlach $(10 \mathrm{x} 1$ $\mathrm{m}^{2}$ ), e outras variações de tamanho (MARCHIORO; AUGUSTIN, 2007).

A parcela de erosão constitui-se de uma moldura retangular de três lados, sendo que um deles fecha a parcela na parte de maior de declividade, e as outras duas são as laterais. As dimensões da parcela são variáveis, dependendo das necessidades do estudo (COELHO NETTO, 2003; DIAS, 2011; GUERRA, 2003; NEGREIROS, 2011; PINESE, 2006; TAKASHI et al., 2008; HUA ZHENG et al., 2008).

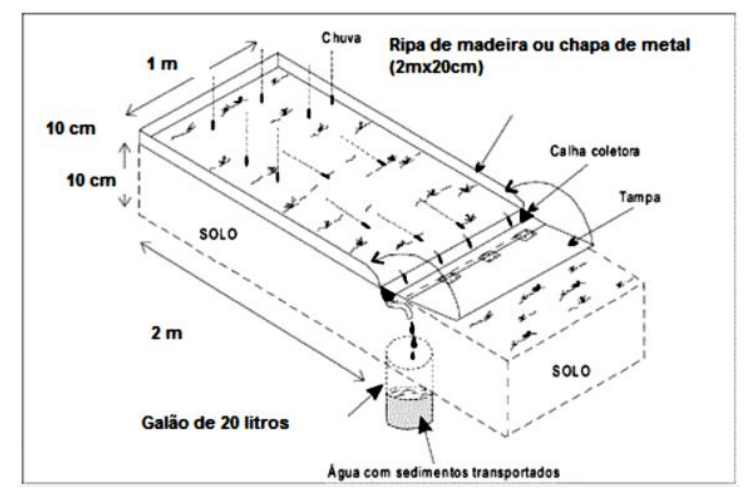

Figura 2.5 - Parcela hidro-erosiva, ou de erosão.

Fonte: Modificado de Guerra (2003).

Esta parcela tem como função conhecer a quantidade de sedimentos perdida e transportada por escoamento superficial em determinada área de tamanho conhecido. 
Segundo Marchioro e Augustin (2007), já foram utilizadas parcelas com dimensões de 46x46 cm para analizar as fases da erosão (MUTCLER; MURPHREE; MCGREGOR, 1988); para mensurar a erosão do solo relacionado à cobertura vegetal com parcelas de $10 \mathrm{~m}^{2}$ ou maior (BRASIL; BERTONI; LOMBARDI NETO, 1999); podendo variar até 100, 250, 500 e $1.000 \mathrm{~m}^{2}$, respectivanente, para saber qual a influência da cobertura em relação à erosão do solo, o resultado de práticas de conservação do solo em cultivo de café, e para avaliar o quanto o comprimento de rampa inflencia na perda de sedimentos (4 últimos tamanhos de área).

Guerra (2010) propôs 2 parcelas, uma ao lado da outra, experimentais com dimensões de $1 \times 10$ m simulando duas situações distintas, tais como solo sem vegetação e solo com vegetação crescendo. A altura sugerida por este autor é de $30 \mathrm{~cm}$, ficando $10 \mathrm{~cm}$ dentro do solo, e $20 \mathrm{~cm}$ para fora para evitar o efeito do salpicamento do solo. Marchioro e Augustin (2007) sugerem que altura seja $33 \mathrm{~cm}, 3$ a mais que Guerra (2010).

No Brasil, as parcelas têm sido utilizadas em pesquisas hidrogeomorfológicas e agrícolas. No sudeste, destacam-se os estudos realizados da Universidade Federal do Rio de Janeiro, dentro do Instituto Alberto Luiz Coimbra de Pós-Graduação e Pesquisa de Engenharia (COPPE-UFRJ). Os estudos dedicam-se à análises hidrogeomorfológicas, no relevo montanhoso lá existente.

Negreiros (2011), utilizou 3 parcelas de erosão adaptadas com área de $6 \mathrm{~m}^{2}$ (3x2 m) para mensurar os sedimentos em uma clareira em estado de recuperação florestal formada por deslizamento (revegetação induzida, revegetação espontânea e borda florestal). O objetivo era conhecer o quanto o solo havia recuperado suas funções depois de ocorrido o deslizamento no ano de 1996, no Maciço da Tijuca, Rio de Janeiro.

Sato (2008), analisou as respostas geo-hidroecológicas de áreas que foram submetidas à substituição de pastagens por plantações de eucaplipto no Médio Vale do Rio Paraíba do Sul. Sato instalou 2 parcelas de $90 \mathrm{~m}^{2}$ (9x10) cada, com 15 exemplrares de eucalipto dentro, sendo uma no divisor, e a outra na encosta lateral. Chegou à conclusão de que a substituição da cobertura do solo de pastagem para eucalipto prpiciou diminuição do escoamento, superficial, aumento da infiltração.

Outro centro pesquisador que utiliza as parcelas de erosão é a Universidade Federal de Uberlândia, Minas Gerais. A universidade possui a Estação Experimental, Fazenda do Glória. 
Bezerra (2006) avaliou o controle da erosão superficial por meio de geotexteis artesanais. Foram instaladas 2 parcelas de erosão de $10 \mathrm{~m}^{2}$ (10x1) e de mesma declividade, sendo uma com solo exposto, e a segunda com geotexteis, aplicação sementes, NPK e calcário. A parcela com geotexteis mostrou ser eficiente na diminuição do escoamento superficial, manutenção da umidade no solo e na contenção da perda de sedimentos.

Falcão, Reis e Souza (2009), instalou 3 parcelas de erosão de $3 \mathrm{~m}^{2}$ na bacia experimental do riacho Gravatá, no sertão alagoano, tendo como cobertura o milho cultivado morro abaixo. Devido ao período estar na estiagem, foi construído simulador de chuvas, controlando-se a lâmina d'água e intensidade da precipitação simulada. O experimento mostrou que o cultivo de milho reduziu a produção de sedimentos para todas as intensidades pluviométricas simuladas, em relação ao solo; a intensidade da precipitação teve relação direta com a taxa de erosão, e que a perda de sedimentos é diretamente proporcional ao aumento do escoamento superficial.

Os sedimentos transportados e o escoamento superficial ocorrido dentro da parcela são coletados por uma calha localizada na face abeta da parcela a qual terá uma saída, ligada a um reservatório que os armazenará.

A calha deve ter o mesmo comprimento dos limites superior e inferior da parcela. A sua calibragem deve ser suficiente para receber o escoamento superficial e os sedimentos, tendo em vista chuvas intensas diárias, e muitos dias com chuvas de longa duração, o que poderia causar uma enxurrada.

A ligação entre a calha e o reservatório pode ser feita por mangueira ou por tubulação, e a sua calibragem deve ser suficiente para que não fique obstruída em casos de uma produção sedimentar muito grande.

Quanto ao armazenamento do produto do escoamento superficial e dos sedimentos transportados, o recipiente deve ter capacidade para armazenar nas mesmas condições de precipitação citadas acima. Outro fator que influencia o processo decisório quanto a este tamanho é a frequência de coleta. A coleta pode ser realizada logo após o evento de precipitação, algumas horas depois, semanalmente ou quinzenalmente, por exemplo.

Dentre os critérios utilizados para a escolha das áreas de instalação das parcelas hidroerosivas com vistas à mensuração de perda de sedimentos por escoamento superficial em encostas é a declividade local. A declividade para este tipo de experimento deve variar entre 
$5^{\circ}$ e $15^{\circ}$ (COELHO NETTO, 2003). A declividade é um dos controles da produção e transporte de sedimentos, juntamente à força da gravidade e à rugosidade da superfície.

Outro critério é qual tipo de cobertura e uso do solo que se quer amostrar. O ideal é que se escolha tipos bem definidos, comparáveis, que haja uma área controle. Por exemplo: amostrar a vegetação natural local e um uso de solo comum da região. Assim, poderá ser mensurado como a mudança de cobertura e uso do solo original por um outro uso, tal como um uso agrícola. Porém, há que se definir qual o tipo de cultura será acompanhada, pois cada cultivo e forma de cultivo responde de forma distinta à perda sedimentar.

A existência ou não de cobertura vegetal no solo, sua estrutura, estágio de desenvolvimento das espécies, quais espécies existem, formação ou não de dossel. A formação de serapilheira devido à queda de folhas das árvores também é um fator importante nesta análise. Todos estes elementos influenciam o escoamento superficial, a infiltração e a produção sedimentar local.

Para permitir a coleta dos dados e a manutenção dos equipamentos, a facilidade de se chegar ao local, com estradas em estado de conservação razoável, é mais um critério de escolha.

Garantir a segurança dos equipamentos também é fundamental para que não haja perda de dados, nem prejuízos materiais com reposição de peças ou instrumentos de mensuração. Então, é importante que os equipamentos sejam instalados em área cercada, ou vigiada, bem sinalizada.

A mensuração da quantidade de chuva que cai sobre a parcela é feita por pluviômetros ou pluviógrafos.

\subsection{BIOMA CERRADO: FITOFISIONOMIAS, CLIMA E CARACTERISTICAS DOS SOLOS}

O Cerrado é um dos biomas mais ricos do planeta, e possui a segunda maior biodiversidade do país. O Cerrado tem uma especificidade de ser um mosaico natural de fitofisionomias que transitam de uma para a outra a depender das condições de solo, declividade e da oferta hídrica, entre outros fatores, formando assim, grande diversidade florística. 
Ribeiro e Walter (1998) classificaram o Cerrado em três formações vegetais, sendo elas: florestal, campestre e savânica.

A formação florestal do Cerrado, geralmente, ocorre em solos profundos no topo das chapadas; ou em lentes de calcário (no caso de Matas Mesofítica); ou acompanhando o leito dos rios (Matas de Galeria, Ciliar, ou Ripária); e o Cerradão, com árvores um pouco mais baixas. Nesta formação encontram-se árvores de grande porte que formam dossel, além de cipós, samambaias. A presença de serapilheira também ocorre neste ambiente, devido à queda de folhas das árvores e que se acumulam no solo, decompõem-se realimentando o solo e as raízes das plantas florestais (RIBEIRO; WALTER, 1998).

A formação savânica do Cerrado é composta pelas fitofisionomias Cerrado Denso, Cerrado Típico, Cerrado Ralo, Parque do Cerrado (transição de vegetação mais densa e alta, com árvores e arbustos, para uma mais rala e baixa, com maior parte de arbustos, sempre com a presença de gramíneas), Palmeiral (Babaçual, Buritizal, Guerobal, Macaubal), Vereda (vegetação formada por buritis e gramíneas, em solo encharcado, hidromórficos) e Cerrado Rupestre (RIBEIRO; WALTER, 1998).

A formação campestre é composta de campo rupestre, campo sujo e campo limpo, herbáceo, variando entre subarbustivo, arbustivo, com ou sem a presença de árvores ou arvoretas esparsas, além de gramíneas (RIBEIRO; WALTER, 1998).

As fitofisionomias do cerrado estão relacionadas, principalmente ao tipo de solo e à disponibilidade hídrica. Além disso, existem outros controles, tais como, relevo, declividade, altitude, geologia, estrutura, etc. Cada fitofisionomia possui suas características: além do tipo do solo no qual se desenvolvem, o tipo de formação (florestal, savânica e campestre), onde variam a densidade do dossel, a altura do dossel, a cobertura do solo, a formação de serrapilheira, a biomassa das raízes, e, possivelmente, o volume de infiltração, escoamento superficial e erosão. Sendo alterada a cobertura do solo com o uso antrópico, esse volume devem ser alteradas, diminuindo a estabilidade do solo, e propiciando a erosão.

A cobertura vegetal exerce múltiplas funções no ciclo hidrológico, tais como: interceptação da água chuva pela copa das árvores, onde parte será absorvida, parte atravessará a copa e chegará ao solo, diminuindo a energia potencial e cinética dos pingos de água que chegarão ao solo; formam a serapilheira que se decompõe e realimenta o solo e as 
plantas; as raízes aumentam a porosidade do solo, a areação, a capacidade de infiltração e percolação.

Geralmente, as formações florestais têm mais de um extrato arbóreo, o que contribuiria para reduzir os efeitos do atravessamento. Além disso, nesse tipo de vegetação também é formada a serapilheira, sendo ela uma camada de restos de plantas (folhas, galhos, cascas, flores e frutos) e insetos que sofrem decomposição e são responsáveis por cobrir o solo e fazer uma ciclagem de nutrientes. Podem formar uma ou duas camadas, os horizontes $\mathrm{O} 1$ e $\mathrm{O} 2$ do solo, sendo o primeiro a camada mais superior de material que caiu recentemente sem ter entrado em decomposição, e a segunda do material já começou a se decompor (COELHO NETTO, 2003). 


\section{MATERIAIS E MÉTODOS}

\subsection{INSTRUMENTOS DE MENSURAÇÃO}

As parcelas de erosão instaladas consistem em três de bordas de chapa galvanizada (duas de $2 \mathrm{~m}$ de comprimento e uma de $1 \mathrm{~m}$ de largura, por $20 \mathrm{~cm}$ de altura), sendo que $10 \mathrm{~cm}$ são fincados no solo e $10 \mathrm{~cm}$ acima do solo.

A borda superior (de 1m) impede que o escoamento superficial ocorrido acima dela entre na parcela. Na parte inferior, com largura de 1m, há uma calha de PVC coletora de 150 $\mathrm{mm}$ de calibre cortada ao meio para coletar toda água escoada superficialmente e os sedimentos produzidos e transportados dentro da parcela. As calhas foram cobertas com telha para que a precipitação não caiasse diretamente sobre ela, não alterando os dados de escoamento superficial. Neste projeto foram utilizadas telhas de 50 x $1,24 \mathrm{~cm}$ de cumprimento, amarrados com um arame para que o vento não as retirasse do lugar. A água escoada e os sedimentos foram armazenados em um galão de 50 litros.

A mensuração da entrada de chuva no sistema foi realizada por meio de pluviômetros artesanais. Os pluviômetros têm uma haste de $1 \mathrm{~m}$ de altura, e uma base de madeira que segura um galão de 5L que será o reservatório da precipitação. Um funil de 12,7 cm de diâmetro é a entrada de precipitação. Uma bola de pingue-pongue fica dentro do funil para que a água depositada não seja evaporada, nem insetos entrem no reservatório, preservando os dados. A bola é leve o suficiente para que flutue permitindo que a precipitação passe pelo funil. 

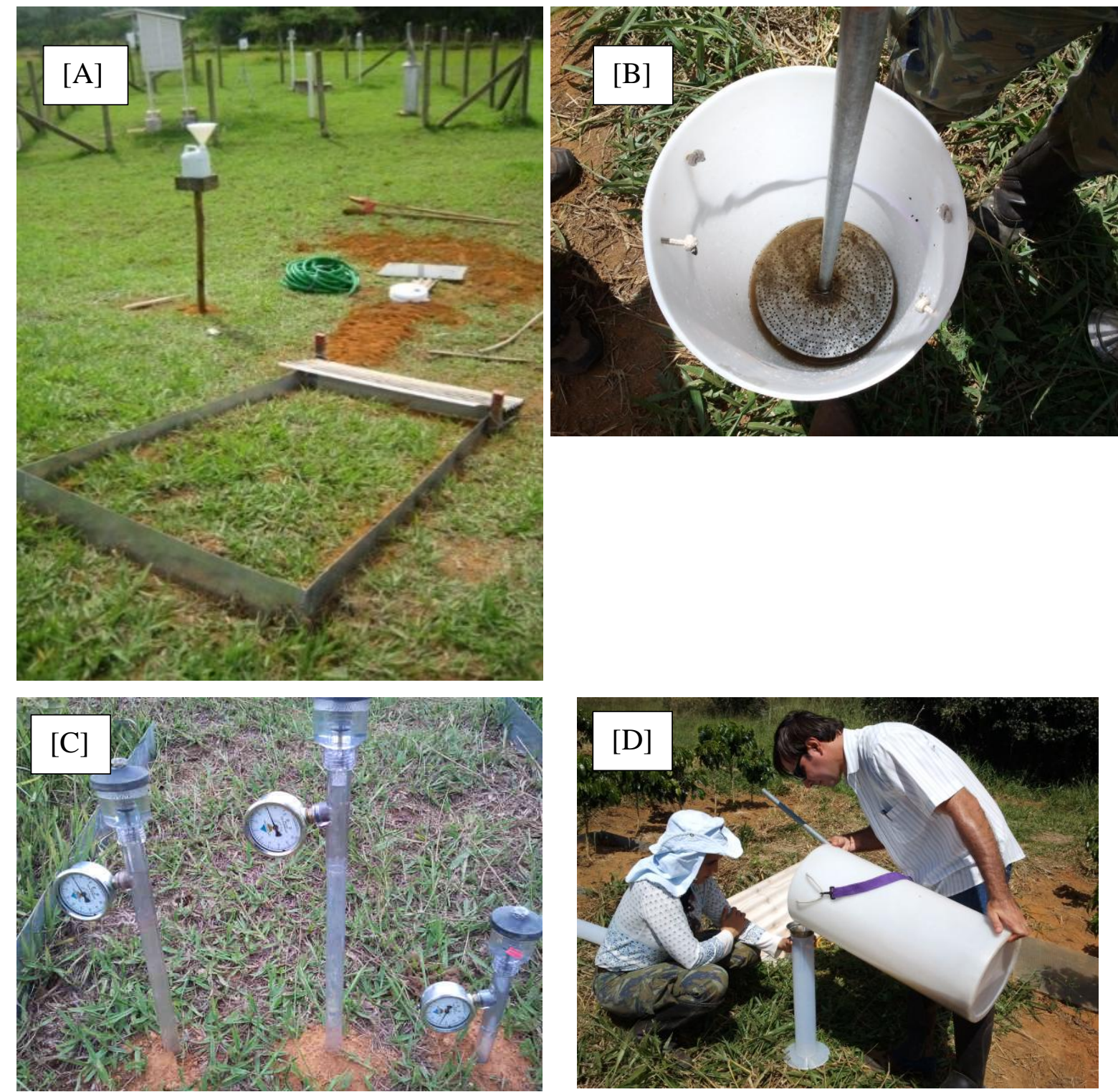

Figura 3.1 - [A] Parcela de erosão na Estação Gramínea com pluviômetro artesanal ao lado; [B] Balde e agitador para agitação da amostra; [C] Bateria de tensiômetros instalada na Estação Gramínea; [D] Coleta de escoamento superficial e de sedimentos na Estação Café - Fazenda Água Limpa.

Os pluviômetros foram instalados ao lado das parcelas. Na Mata de Galeria e no Cerrado denso, aonde a precipitação que chega ao solo é influenciada pela copa das árvores, foram instalados nove e cinco pluviômetros, respectivamente, perto e entre os troncos para que se possa medir a variação da precipitação em relação ao atravessamento. 


\subsection{ANÁLISE LABORATORIAL}

Os sedimentos transportados nas parcelas foram coletados com a periodicidade semanal. Em alguns momentos, os intervalos entre as coletas foi maior, chegando até 1 mês. Os sedimentos transportados para os galões instalados junto de cada parcela tem seu volume medido em uma proveta de plástico graduada de $2000 \mathrm{ml}$. Quando os volumes do escoamento superficial e de sedimento excederam ao volume da proveta, depois de medidos, são colocados em um recipiente de $40 \mathrm{~L}$. A amostra é agitada com um agitador feito de uma chapa circular de $27 \mathrm{~cm}$ de diâmetro de ferro galvanizado e furos com distância de $1 \mathrm{~cm}$ entre si, formando círculos concêntricos. O agitador tem no centro uma barra circular de ferro galvanizado com 1,50 m de comprimento.

As amostras foram agitadas dez vezes, tornando a amostra uma mistura homogênea. Segundo Negreiros (2011), a homogeneização da amostra torna-se necessária para que não haja predomínio de sedimentos da fração em suspensão. Quando estiver homogênea, é coletada uma subamostra de $1 \mathrm{~L}$, em frascos em PE de boca estreita com tampa de rosca e graduados. Quando necessário, foi utilizada uma pisseta de 1L com volume de água conhecido para a coleta de todos os sedimentos que estiverem nos galões. Desta forma, podese saber quanto a amostra foi diluída na coleta, sem alterar o dado de concentração de sedimentos (gramas) por litro de água escoada superficialmente.

A análise da massa de sedimentos transportada foi feita utilizando-se dois procedimentos distintos. Parte das amostras coletadas foram analisadas pelo método da evaporação, tendo sido secadas em estufa à temperatura de $105^{\circ} \mathrm{C}$, em beckers de peso conhecido. Após secagem, a amostra era pesada para se obter o seu peso seco, diminuindo-se o peso do Becker. O peso final é multiplicado pelo volume total do escoamento superficial, e divido pelo volume da amostra, de acordo com a Fórmula 1.

$$
\frac{\mathrm{V}_{\text {total }}}{\mathrm{V}_{\text {amostra }}}=\frac{\mathrm{P}_{\text {total }}}{\mathrm{P}_{\text {amostra }}}
$$

Onde:

$\mathrm{V}_{\text {total }}$ - é o volume total do escoamento superficial e sedimentos;

$\mathrm{V}_{\text {amostra }}$ - é o volume coletado de até 1 , a depender do volume total do escoamento superficial e sedimentos; 
$\mathrm{P}_{\text {total }}$ - peso total dos sedimentos coletados; e

$\mathrm{P}_{\text {amostra }}$ - é o peso dos sedimentos da amostra de até 11 , a depender do volume total do escoamento superficial e sedimentos.

Outra parte das amostras foi analisada pelo método da filtração, onde a amostra (líquido + sólidos) é colocada em um recipiente com um papel filtro com malha $\leq 0,47 \mathrm{~mm}$, sendo este pesado. Uma bomba à vácuo realiza a sucção da parte líquida, enquanto os sedimentos são retidos no papel filtro. A filtragem, os papéis filtros com os sólidos são levados à estufa por 24 h, à temperatura de $100^{\circ} \mathrm{C}$. após a secagem, são levados ao dissecador para que cheguem à temperatura ambiente, sem que ganhem mais umidade, podendo, assim, serem pesados. A massa de sedimentos da amostra foi obtida pela subtração do peso do papel filtro seco com sedimentos pelo peso do papel filtro limpo.

A obtenção da massa de sedimentos transportados por metro quadrado foi utilizada a seguinte Equação (3.2) (NEGREIROS, 2011):

$$
M=\frac{s . f}{a . c}
$$

Onde:

$M$ - Relação de sedimento transportado por metro quadrado $\left(\mathrm{g} / \mathrm{m}^{2}\right)$

$s-$ Total de sedimentos transportados por parcela $(\mathrm{g})$

$f$ - Total de escoamento superficial por parcela (L)

$a$ - Área da parcela experimental $\left(\mathrm{m}^{2}\right)$

$c$ - Quantidade de amostra coletado (L)

"A homogeneização das amostras torna-se importante, com o propósito de não

A análise granulométrica, que visa obter o tamanho dos grãos da amostra de solo foi realizada de acordo com a metodologia utilizada por Embrapa (1997), no Laboratório de Estruturas e Construção Civil - Infralab -, do Departamento de Geotecnia da Faculdade de Tecnologia, da Universidade de Brasília.

A precipitação foi medida em campo com uma proveta graduada de $2000 \mathrm{ml}$. O volume foi convertido de $\mathrm{ml}$ para $\mathrm{mm}^{3}$. Depois, a altura de chuva foi calculada por meio da seguinte equação (COELHO NETO, 1995):

$$
V=\pi r^{2} h
$$


Onde:

V é o volume precipitado;

$\pi$ é a contante matemática igual a $3,1415927 \ldots$;

r é o raio do funil, cujo valor é $127 \mathrm{~mm}$;

h é a altura da precipitação, em mm.

Os dados foram anotados em um caderno de campo, onde posteriormente foram sistematizados e analisados, tanto quanto a variação no tempo e no espaço. Os dados colhidos dos pluviômetros artesanais com medição semanal forneceram a precipitação acumulada do período; e foram comparados com dados de estação pluviométrica instalada na Fazenda Água Limpa, com a estação pluvio-fluviométrica da ANA FAL-UNB Código 6047848, além de um pluviômetro instalado por Távora próximo às estações de cerrado e mata de galeria, todas medindo dados de chuva em intervalos de 15 em 15 minutos, por exemplo, podendo-se obter a intensidade da precipitação de cada período.

\subsection{TENSIOMETRIA}

Os tensiômetros são instrumentos que medem a tensão, ou potencial matricial da água no solo. São tubos plásticos fechados hermeticamente preenchidos com água destilada, ou fervida e fria, com uma ponta de cerâmica porosa. A ponta porosa permite que haja troca entre a água que está dentro do tensiômetro e no solo, de acordo com a variação do volume da água. A parte superior é vedada e encontra-se um medidor de tensão, o vacuômetro graduado de 0 a $100 \mathrm{cb}$. O aumento da tensão gera um vácuo dentro do tubo tensiométrico que é medido em Centibar (cb). A unidade de medida de tensão do solo usada internacionalmente é Quilopascal $(\mathrm{kPa})$, que equivale a 1 Centibar, e por isso, será usada neste trabalho. Geralmente, os tensiômetros são instalados em baterias em diversas profundidades de modo a permitir conhecer a disponibilidade hídrica, seja superficialmente, ou subsuperficialmente. Foram instaladas cinco baterias de tensiômetros - uma para cada uso do solo - nas profundidades 10 , 20 e $45 \mathrm{~cm}$. Para o uso do solo "Solo Exposto", foi retirada a gramínea que cobria o solo, fazendo com que os tensiômetros ficassem submetidos às mesmas condições do solo nas parcelas.

A tensão da água no solo relaciona-se ao volume de água existente. Quanto mais água presente no perfil, menor é a força exercida para manter a umidade nos macro e microporos. 
À medida que ocorre a evaporação e o uso da água pelas plantas, as gotas da água são retidas nos microporos causando um aumento da tensão. Dessa forma, a água presente no tensiômetro vai para o solo criando vácuo dentro do tubo, e que pode ser medido pelo vacuômetro. Quando a umidade do solo aumenta, a água entro dentro do tensiômetro, diminuindo a tensão. A tabela a seguir é um guia para interpretação de leituras tensiométricas.

Tabela 3.1 - Guia para interpretação de leituras de tensiômetros.

\begin{tabular}{|c|c|c|}
\hline Condição & $\begin{array}{l}\text { Leitura } \\
\text { (cbar) }\end{array}$ & Interpretação \\
\hline \multirow[t]{4}{*}{ Saturação } & 0 & Acumulação de água; \\
\hline & & Nível freático raso; \\
\hline & & Aeração prejudicada; \\
\hline & & Tensiômetro com vazamento. \\
\hline \multirow[t]{2}{*}{ Capacidade de campo } & 6 a 10 & Ponto para interrupção das irrigações. \\
\hline & & $\begin{array}{l}\text { Evitar percolação de água e lixiviação de } \\
\text { nutrientes. }\end{array}$ \\
\hline \multirow[t]{6}{*}{ Momento de aplicação } & 20 a 40 & $\begin{array}{l}\text { Irrigações dirigidas para produtividade } \\
\text { máxima e culturas de maior valor } \\
\text { econômico e solos arenosos; }\end{array}$ \\
\hline & & Valor usual para iniciar irrigações; \\
\hline & & Aeração assegurada; \\
\hline & & Solos de textura média. \\
\hline & 40 a 50 & Início de irrigação em solo argiloso; \\
\hline & & Manutenção da unidade disponível. \\
\hline \multirow[t]{3}{*}{ Intervalo de irrigação } & 50 a 60 & Valor de início de déficit; \\
\hline & & Alguma umidade disponível; \\
\hline & & Risco de perda de produção. \\
\hline Seco & 70 a 80 & \\
\hline
\end{tabular}

Fonte: Adaptado de James ${ }^{8}$ apud Azevedo e Silva, 1999.

${ }^{8}$ JAMES, L. G. Principles of farm irrigation system design. New York: J. Wiley, 1988. 543p. 


\title{
4. MENSURAÇÃO DE PERDAS DE SEDIMENTOS POR ESCOAMENTO SUPERFICIAL EM ENCOSTAS, COM USO DE PARCELAS DE EROSÃO, EM DIFERENTES USOS E COBERTURAS DO SOLO NO BIOMA CERRADO: BACIA HIDROGRÁFICA DO RIBEIRÃO DO GAMA/DF
}

\begin{abstract}
RESUMO
A mensuração do volume de infiltração, de escoamento superficial e de erosão é de fundamental importância na prevenção de desastres naturais, nas práticas de conservação do solo e no planejamento urbano e rural. A precipitação é medida por meio de pluviômetros ou pluviógrafos. A mensuração das variáveis infiltração e escoamento superficial, e também de produção e transporte sedimentar, pode ser feita utilizando-se as parcelas hidro-erosiva, ou de erosão. Para instalação deste instrumento, faz-se necessário adotar certos critérios, tais como: inclinação variando entre 5 e $20^{\circ}$; proximidade de estradas para facilitar a instalação, manutenção e coleta de dados; ter um relevo o mais retilíneo possível; ter exemplares com características distintas de uso e cobertura do solo, para permitir uma comparação entre os resultados. Esta dissertação tem como objetivo mensurar a produção de sedimentos causados por escoamento superficial em encostas no Bioma Cerrado com a instalação de 15 (quinze) parcelas de erosão, em 5 (cinco) áreas distintas - gramínea simulando o uso urbano, solo exposto, cultivo de café plantado em curvas de nível, Cerrado e Mata Ciliar -, sendo 3 (três) em cada área, segundo os critérios acima citados, na Bacia do Ribeirão do Gama, DF. A perda de sedimentos (toneladas/ha.ano) será calculada por uma alíquota de $1000 \mathrm{ml}$ do total de escoamento superficial. Os resultados demonstram uma maior perda de sedimentos nos locais com alteração da cobertura original do solo e com chuvas de maior intensidade.
\end{abstract}

PALAVRAS-CHAVE: balanço hídrico; perda de sedimentos; escoamento superficial.

\begin{abstract}
The measurement of runoff, percolation and surface erosion is central to the prevention of natural hazards, soil conservation and rural/urban planning. The rainfall is measured by manual and automatic rain gauges. Numbers of percolation and surface erosion can be obtained by erosion plots. Installation criteria are necessary to the measurement, as such: inclination between $5^{\circ}$ and $20^{\circ}$; easy access; disctints land use and phytophysiognomy.

This work ains to study the sediment production regulated by runoff in the cerrado (savana) biome. We have been instaled 15 microplots in 5 disctints uses ( 3 for area): grass, exposed soil, coffee plantation, cerrado (savana) and riparian forest, on the Gama basin/DF. The soil loss (tons/he/year) will be obtained by with an aliquot of $1000 \mathrm{ml}$. The results shown a greater soil loss on the uncovered areas and during heavy rainfall.
\end{abstract}

KEY-WORDS: water balance; sediment loss; runoff. 


\section{INTRODUÇÃO}

A intensificação do crescimento urbano e agrícola sobre o Bioma Cerrado tem propiciado alteração em sua cobertura vegetal. Essas alterações modificam a relação que existe entre a infiltração da água da chuva no solo, o escoamento superficial e a erosão.

O escoamento superficial é um processo hidrogeomorfológico natural que acontece a partir das condições de precipitação, vegetação e tipo do solo. Porém, o seu incremento por meio da impermeabilização do solo, mudança de uso e exposição da superfície do solo tornase uma das maiores causas de assoreamento de canais e contaminação de corpos hídricos. Além disso, o seu aumento também pode ocasionar enchentes e alagamentos, ao aumentar a vazão dos rios e lagos.

O escoamento superficial é o fluxo de água que escoa sobre o solo e que pode carregar consigo as partículas soltas e os contaminantes presentes, levando até os fundos de vale. Existem três tipos de escoamento superficial: o escoamento superficial Hortoniano (storm runoff), fluxo de retorno (return flow) e o fluxo de escoamento de saturação (saturation overland flow) (DUNNE; LEOPOLD, 1978).

O escoamento superficial Hortoniano ocorre quando a capacidade de infiltração do solo é excedida pela intensidade da chuva. As taxas de infiltração do solo diminuem com o tempo, no decorrer do evento pluviométrico (CHORLEY, 1980). A água infiltra-se até que a superfície do solo torna-se saturada, não permitindo absorver mais umidade naquele instante. Assim, a água excedente começa a se acumular em pequenas reentrâncias da superfície, formando armazenamento de depressão. Quando esta capacidade de armazenamento esteja saturada, a água transborda e passa a fluir encosta abaixo, até chegue ao fundo de vale.

A capacidade de infiltração é controlada por determinados elementos, tais como: características físicas do solo (composição - \% de argila, silte e areia; textura), além da existência ou não de cobertura, da formação ou não de dossel (e sua espessura) e da sua qualidade. Solos argilosos geralmente são menos drenados, pois as partículas de argilas funcionam como um coloide, atraindo as moléculas de água e solutos pra si com demasiada força, tampando os poros existentes. Assim, a água movimenta-se no solo muito lentamente, tornando-o saturado mais rapidamente (BRADY; WEIL, 2013). 
Solos arenosos são bem drenados, porém não retém muita umidade com a finalidade de disponibilizá-la para as plantas. Seus grãos são muito grandes, e a água passa rapidamente pelo perfil. Em termos da relação infiltração e escoamento, pode ser problemático se o horizonte superficial do solo for arenoso, e o horizonte logo abaixo for mal drenado, como por exemplo, um argiloso (BRADY; WEIL, 2013). Isso geraria um fluxo subsuperficial que escoaria pelo horizonte permeável de forma lateral até escoar para fora da encosta, atingindo o canal fluvial (BRADY; WEIL, 2013). O fluxo subsuperficial pode gerar erosão na zona de contato entre os dois horizontes, formando os pipes, que são galerias subterrâneas por onde a água flui. Com o crescimento dos pipes, o solo acima deles pode perder sua capacidade de se manter e colapsar, gerando uma voçoroca (COELHO NETTO, 2003). Os solos com maior teor de silte, geralmente são bem drenados, e conseguem reter umidade e disponibilizar às raízes e microorganismos.

Com relação à cobertura e uso do solo, a retirada da vegetação natural ocasiona na mudança na estrutura dos agregados do solo, deixando as partículas mais soltas e mais propensas a serem transportadas pelo vento ou pela chuva (BRADY; WEIL, 2013). Se, após a supressão vegetal, a superfície não for coberta adequadamente, o solo fica sujeito ao ressecamento (perda de umidade), e com isso, dependo do tipo do solo, gerar rachaduras (COELHO NETTO, 2003). Durante a precipitação, os pingos da chuva caem sobre a superfície com elevada energia cinética (o valor muda de acordo com a intensidade, duração e diâmetro dos pingos) desprendendo as partículas menos agregadas e fazendo com que eles respinguem (salpicamento, splash). A água penetra por entre as fissuras levando consigo essas partículas de solo em solução. Esses solutos preenchem as rachaduras e demais poros, impedindo a infiltração da água (COELHO NETTO, 2003).

Quando o solo é coberto por alguma vegetação, a folhas, caules e tronco auxiliam a interceptar parte da precipitação. O que a planta não conseguir absorver, será escoado pelo tronco (stem flow), ou será gotejado pelas folhas (atravessamento, ou throughfall). Ambos, o fluxo de tronco e o atravessamento, proporcionam que a água excedente chegue à superfície com menos força (COELHO NETTO, 2003; SATO, 2011; TRICART, 1977). As gramíneas (nativas ou não) também exercem esta função de interceptação da água da chuva, além de serem obstáculos ao escoamento superficial. As raízes realizam o trabalho de tornar o solo mais aerado, aumentando a quantidade e tamanho dos poros do solo, e consequentemente, aumentando a infiltração. 
À medida que a água infiltra, esta umidade alimenta o lençol freático, que é o que forma o escoamento de base (base flow) dos rios, deixando-os perenes durante o período da seca. A contribuição da água da chuva no volume do lençol freático, o eleva, elevando também a área de saturação do solo. Quando a área saturada encontra a encosta, a água subsuperficial pode minar e escoar pela superfície até chegar ao canal fluvial, formando o fluxo de retorno. Este tipo de fluxo superficial e o escoamento superficial Hortoniano que serão usados nestas pesquisa.

Menezes (2010), em estudo feito para avaliar o efeito da mudança de uso do solo dentro da bacia do Lago Paranoá, traz dados de relatório da Companhia de Saneamento ambiental do Distrito Federal (Caesb, 2003) que mostram a existência de $9,2 \mathrm{~m} / \mathrm{m}^{2}$ de sedimentos assoreando os braços da bacia do Paranoá, em todas as suas unidades hidrográficas. A área do espelho d'água do Lago Paranoá que foi perdida, do ano de 1966 até 2009 , é de $0,75 \mathrm{~km}^{2}$, cerca de $2 \%$ da área do reservatório (MENEZES, 2010).

Com a possibilidade de se utilizar as águas do Lago Paranoá para abastecimento público do Distrito Federal, o estudo da mensuração direta do escoamento superficial e das perdas de solo dentro da bacia faz-se necessário. Este trabalho tem como objetivo conhecer o comportamento hidroerosivo dos solos em cinco diferentes tipos de uso e cobertura, mensurando o escoamento superficial e produção sedimentar no Bioma Cerrado, além da correlação entre estas variáveis e a tensão da água no solo, tendo como estudo de caso a Bacia do Ribeirão do Gama. Os resultados podem oferecer subsídios para calibração de modelos preditivos, tais como o SWAT (Soil and Water Assessment Tool), e auxiliar a tomada de decisão quanto ao planejamento territorial urbano do Distrito Federal.

\section{Área de estudo: Bacia do Ribeirão do Gama}

A área de estudo é a bacia hidrográfica do Ribeirão Gama (Figura 4.1), localizada na região sul do Distrito Federal, Brasil, com uma área de aproximadamente $137 \mathrm{Km}^{2}$, entre as coordenadas de $15^{\circ} 50^{\prime}$ e $16^{\circ}$ de latitude sul e $47^{\circ} 50^{\prime}$ e $48^{\circ}$ de longitude oeste (CARVALHO et al., 2001). O Ribeirão do Gama nasce na Mata do Catetinho, recebendo as águas dos Córregos do Mato Seco e Cedro, afluentes da sua margem esquerda, e dos Córregos Taquara e Capetinga, afluentes da margem direita, desaguando no Lago Paranoá com uma vazão média de $1,85 \mathrm{~m}^{3} / \mathrm{s}$ (MOURA, et al., 2010). 
A escolha da Bacia do Ribeirão do Gama deveu-se pela existência de vegetação do Bioma Cerrado preservada e de diversos tipos de uso na área como unidades de conservação (APA Gama cabeça de Veado, Reserva Ecológica do IBGE, Estação Experimental da UnB - a Fazenda Água Limpa, e Estação Ecológica do Jardim Botânico de Brasília, Áreas de Relevante Interesse Ecológico do Bosque e Capetinga-Taquara), áreas urbanizadas (as regiões administrativas Park Way, Núcleo Bandeirante e Lago Sul, com diferentes graus de consolidação urbana) e áreas agrícolas (Núcleo Rural Vargem Bonita e Núcleo Rural Córrego Onça) (UNESCO, 2003; CARVALHO et al., 2001).

A geomorfologia da bacia do Ribeirão do Gama possui dois compartimentos geomorfológicos: as Chapadas da Contagem e de Brasília e Depressão do Paranoá. A área de Chapadas é plana e suavemente ondulada, que correspondem à porção sul e sudoeste da bacia. Enquanto que as áreas da Depressão representam as regiões inclinadas e fracamente dissecadas, que partem da base das chapadas em direção aos vales dos cursos d'água (NOVAES PINTO, 1990). A as cotas altimétricas variam de 1.005 a 1.270 metros e possui declividade entre $0 \%$ a $10 \%$ nas áreas de chapada. As encostas apresentam-se suavemente onduladas com declividades $10 \%$ a $20 \%$ e $20 \%$ a $50 \%$ nas áreas mais movimentadas próximas a algumas nascentes, como por exemplo, córrego Capetinga.

De forma geral, a região da bacia do Gama apresenta predomínio da classe pedológica dos Latossolos Vermelhos e Vermelho-Amarelo, podendo ser encontrados nas chapadas e nas bordas das chapadas e encostas, por exemplo (EMBRAPA-SNLCS, 2009). A outra classe de solo encontrada nesta localidade é o Cambissolo presente nas áreas mais movimentadas. E nas proximidades dos cursos d'água predominam os Gleissolos, associados às Várzeas e Matas de Galeria.

O clima da região caracteriza-se por apresentar duas estações bem definidas: verões úmidos, entre os meses de outubro a abril, quando há a intensificação dos índices pluviométricos e a variação da umidade relativa do ar fica em torno de 75\%; e inverno seco, entre os meses de maio a setembro. De acordo com a classificação de Köppen observam-se na região os tipos climáticos: tropical úmido de savana com inverno seco (Aw), cujas temperaturas médias são superiores a $18^{\circ} \mathrm{C}$ em todos os meses do ano e ocorre nas áreas abaixo de 1.000 metros; além dos tropicais de altitude (Cwa, $\mathrm{Cwb}$ ) que ocorrem nas porções mais elevadas, com no Pediplano de Brasília. O regime pluviométrico caracteriza-se por precipitações mal distribuídas durante o ano. A média anual é de aproximadamente $1.600 \mathrm{~mm}$, 
sendo que o mês de janeiro pode apresentar índices de $320 \mathrm{~mm} / \mathrm{mês}$, enquanto que nos meses de junho a agosto as médias chegam a apenas $55 \mathrm{~mm}$.

\section{Localização das áreas de coleta}

Foram instaladas 15 parcelas hidro-erosivas ou de erosão, 17 pluviômetros artesanais, em cinco áreas distintas, dentro da Fazenda Água Limpa da Universidade de Brasília, na Bacia do Ribeirão do Gama. A Figura 4.1 mostra a localização das parcelas dentro da Bacia do Gama.

Para cada local escolhido, há três parcelas e ao menos um pluviômetro artesanal. O número de parcelas escolhido em cada área tem por objetivo a réplica do experimento, proporcionando um exame estatístico, diminuindo as possiblidades de erros e permitindo que as diferenças que possam ocorrer em função de propriedades físicas do solo, tais como a granulometria, porosidade, relevo, inclinação, profundidade e tipos de horizontes; e as diferenças proporcionada pelo tamanho, geometria e direção das raízes, presença e profundidade da serapilheira, e ação de pequenos animais possam ser investigadas.

Os usos do solo escolhidos para a instalação das parcelas foram:

- Mata de Galeria - a mata margeia o Rio Capetinga, afluente do Ribeirão do Gama. Tem cerca de 300 metros de largura a partir da margem, com uma vegetação com certo grau de preservação, apesar de apresentar uma gramínea que não foi possível identificar se é nativa ou exótica. O solo apresenta camada de serrapilheira espessa, e matéria orgânica com certo grau de decomposição. Há também uma malha de raízes finas. As parcelas foram instaladas bem próximas da margem, com as seguintes inclinações: P1 $-20^{\circ}, \mathrm{P} 2-13^{\circ}$, e P3 $-15^{\circ}$. A margem é bastante declivosa, mostrando a dissecação do leito do rio. Ao que se pode observar, quando há o pico das cheias, o rio não chega até onde as parcelas estão. Solo hidromórfico indiscriminado (REATTO, 2004);

- Cerrado - esta vegetação encontra-se ao lado da mata de galeria, com exemplares de árvores de até 3 metros, arbustos e gramíneas. Presença de serrapilheira, com espessura mais fina, devido à menor cobertura do dossel e também pelo tamanho das folhas serem pequenas. Terreno suavente ondulado. Declividade das parcelas: P4 - 9 ${ }^{\circ}$, P5 - 22 $2^{\circ}$, e P6 - 28 . Solo hidromórfico inscriminado (REATTO, 2004); 
- Café - o cultivo de café foi feito em curvas de nível. O solo na linha onde estão os pés de café fica exposto, área mais plana. Entre as linhas, há gramínea, com declividade das parcelas: $\mathrm{P} 7-18^{\circ}, \mathrm{P} 8-17^{\circ}$, e $\mathrm{P} 9-21^{\circ}$. As parcelas abrangeram as duas áreas, linha e entre linhas. Solo ;

- Gramínea - situam-se na área de estação meteorológica da Fazenda Água Limpa. Gramínea comum de gramado, cuja manutenção é feita periódicamente. Inclinação das parcelas: P10 $-28^{\circ}, \mathrm{P} 11-31^{\circ}$, e P12 - $23^{\circ}$. Solo latossolo vermelho.

- Solo Exposto - as parcelas foram instaladas ao lado das parcelas de gramínea, sob

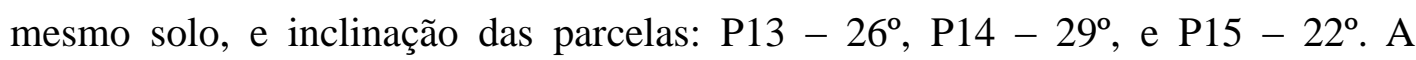
gramínea foi retirada com a aplicação de Glifosato. Os resquícios de raízes foram retiradas manualmente para que não movimentasse muito o solo.

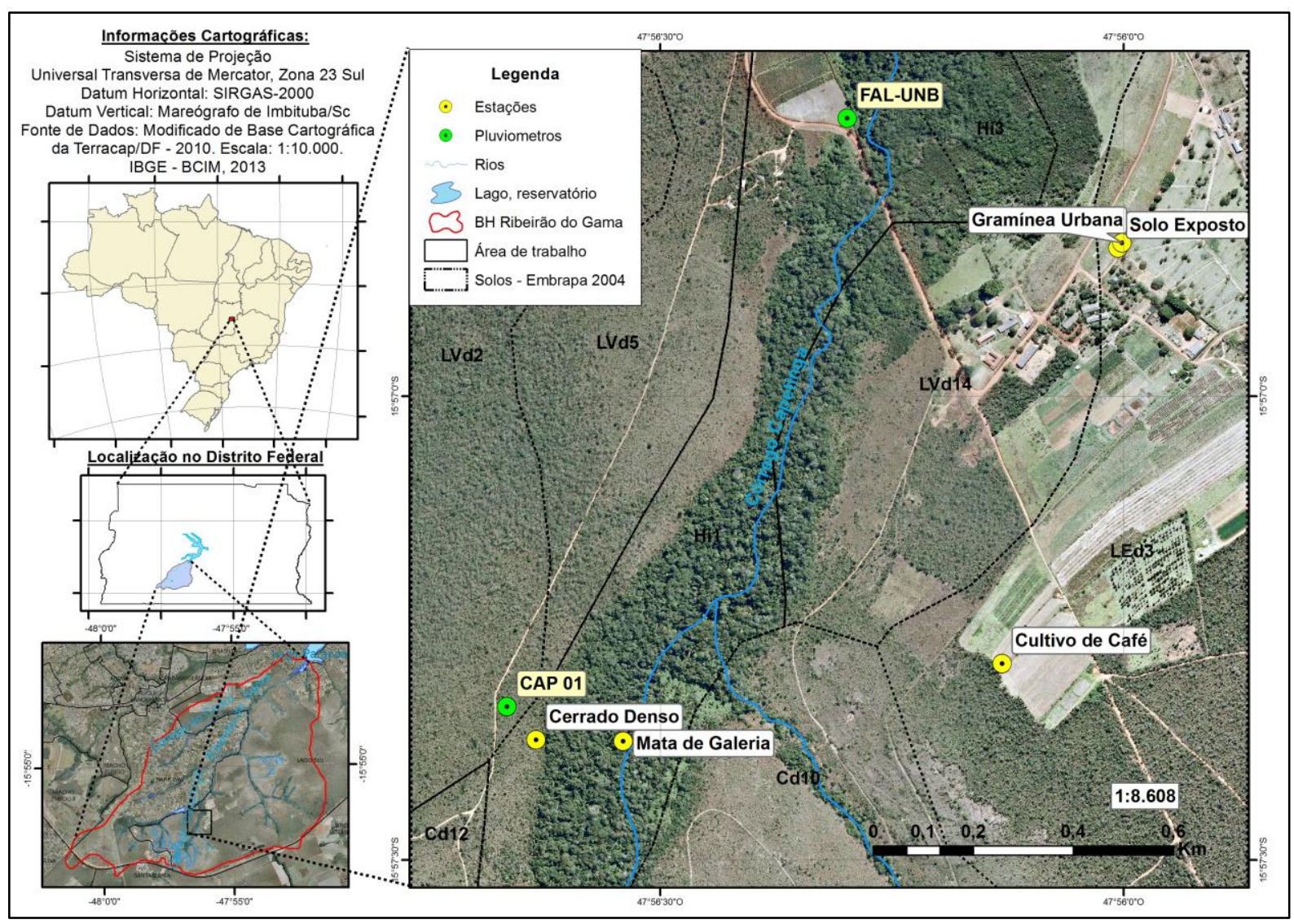

Figura 4.1 - Localização de cada estação de trabalho - Fazenda Água Limpa.

Legenda: Classes de solo: LVd2 - Latossolo Vermelho-Amarelo; LVd5 - Latossolo Vermelho-Amarelo; LVd14 Latossolo Vermelho-Amarelo; LEd3 - Latossolo Vermelho; Cd10 - Cambissolo; cd12 - Cambissolo; Hi1 - Solo Hidromórficos Indiscriminados; Hi3 - Solo Hidromórficos Indiscriminados.

Fonte: modificado de Reatto, 2004. Elaborado pela autora. 


\section{Materiais e Métodos}

A mensuração da entrada de chuva no sistema foi realizada por meio de pluviômetros artesanais. Os pluviômetros foram instalados ao lado das parcelas. Na Mata de Galeria e no Cerrado denso aonde a precipitação que chega ao solo é influenciada pela copa das árvores, foram instalados nove e cinco pluviômetros, respectivamente, perto e entre os troncos para que se pudesse obter o atravessamento da água da chuva.

Além dos pluviômetros artesanais, a precipitação foi monitorada por meio de uma estação pluvio-fluviométrica FAL-UNB, da Agência Nacional de Águas, e do pluviômetro CAP 01 instalado pelo Doutorando Bruno Esteves Távora, do Programa de Pós-Graduação em Tecnologia Ambiental e Recursos Hídricos, no cerrado próximo às estações de Cerrado Denso e de Mata de Galeria. Ambos pluviômetros, forneceram o total de chuva acumulado de cada período, e da intensidade dos eventos ocorridos.

Foram instaladas 15 micro parcelas de erosão do tipo Gerlach, nas dimensões 2x1, com o objetivo de mensurar o escoamento superficial e a produção de sedimentos em cinco tipos distintos de uso do solo. Os usos do solo escolhidos foram: Mata de Galeria (MG), Cerrado Denso (C), Cultivo de Café em curva de nível (CF), Gramínea (GR) e Solo Exposto (SE). Para a estação Solo Exposto, foi usado Glifosato para matar a gramínea existente dentro da área das parcelas, e depois, feita a retirada manual do restante das raízes. A declividade dentro das parcelas é bastante variável, devido aos diferentes usos do solo, e pelas irregularidades do terreno presentes, principalmente, do Cerrado Denso e na Mata de Galeria. Os sedimentos transportados nas parcelas foram coletados, com a periodicidade semanal. $\mathrm{Na}$ segunda e na terceira coleta houve um intervalo maior que 1 semana, devido à ausência de chuvas no mês de janeiro (17 dias). A $6^{\circ}$ coleta teve um intervalo de 28 dias por ausência de dias de chuva, e por problemas técnicos operacionais ocorridos.

Dos sedimentos que tiverem sido transportados com o escoamento superficial, foi retirada sub-amostra de $1 \mathrm{~L}$, depois de homogeneizada por agitação. As sub-amostras foram analisadas em laboratório, pelo método da evaporação, sendo secas em estufa à $105^{\circ} \mathrm{C}$, em béqueres de peso conhecido, para as amostras com alta concentração de sedimentos. As demais sub-amostras foram analisadas pelo método da filtração, usando papel filtro de 0,47 mm e bomba de sucção à vácuo. As sub-amostras com valor menor que 11 devido ao baixo escoamento superficial, foram extrapoladas para que se obtivesse o valor $\mathrm{g} / \mathrm{l}$. 
Amostras do solo deformadas foram coletadas do canto superior direito externo de cada parcela para análise granulométrica, à profundidade de 0 a $10 \mathrm{~cm}$. O método utilizado foi o mesmo da EMBRAPA (1997 e 2012).

Foram instaladas 05 baterias de tensiômetros, uma em cada estação, nas profundidades 10, 20 e $45 \mathrm{~cm}$. Na estação SE, foi retirada a gramínea do solo para que os tensiômetros estivessem submetidos à mesma condição de uso do solo da respectiva estação. AVELAR (2014), utilizou as profundidades 10 e $20 \mathrm{~cm}$ para o "estudo do início da infiltração e as variações decorrentes da absorção de água pelas raízes das diferentes coberturas vegetais", e a de profundidade de $50 \mathrm{~cm}$ para "recarga na zona não-saturada", com observações diárias. As observações deste trabalho ocorreram semanalmente nos dias de coleta das sub-amostras de sedimentos. Durante o mês de abril, pode-se fazer a leitura quase diária, principalmente das estações GR, SE e CF.

As Figuras Figura 4.2, Figura 4.3, Figura 4.4, Figura 4.5 e Figura 4.6 mostram as parcelas instaladas nos Usos do Solos Gramínea, Café, Solo Exposto, Mata de Galeria e Cerrado, respectivamente. 


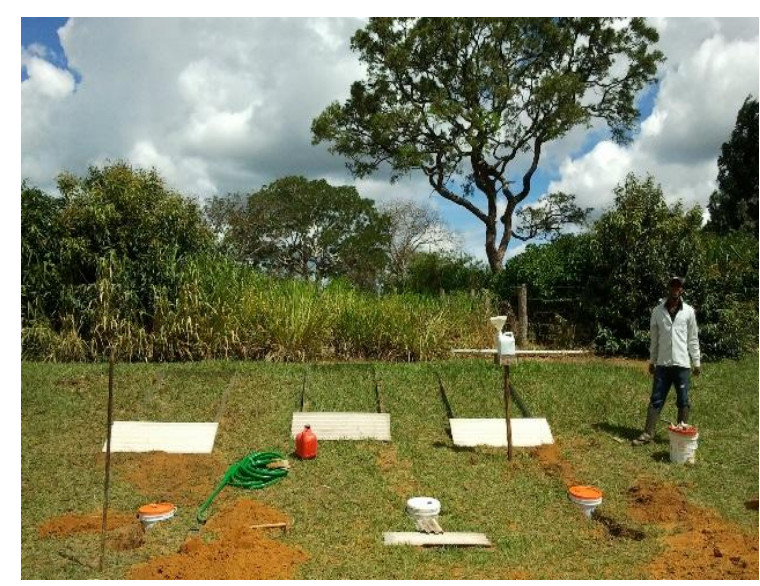

Figura 4.2 - Parcelas de erosão em Gramínea

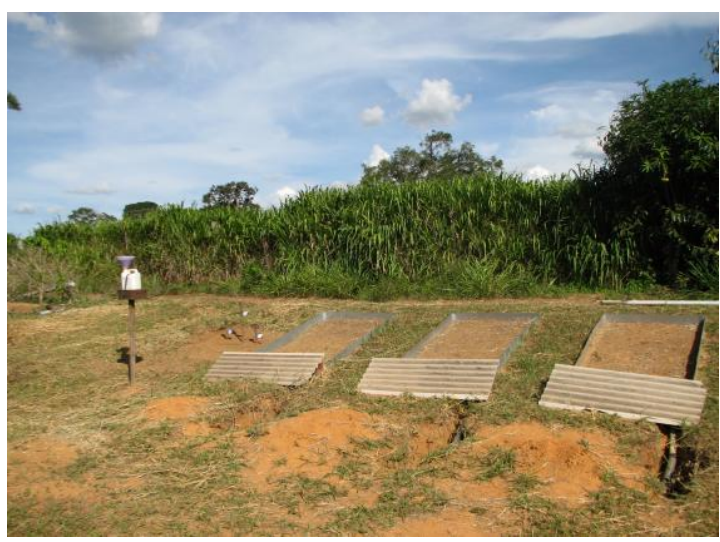

Figura 4.4 - Parcela de erosão no Solo Exposto.

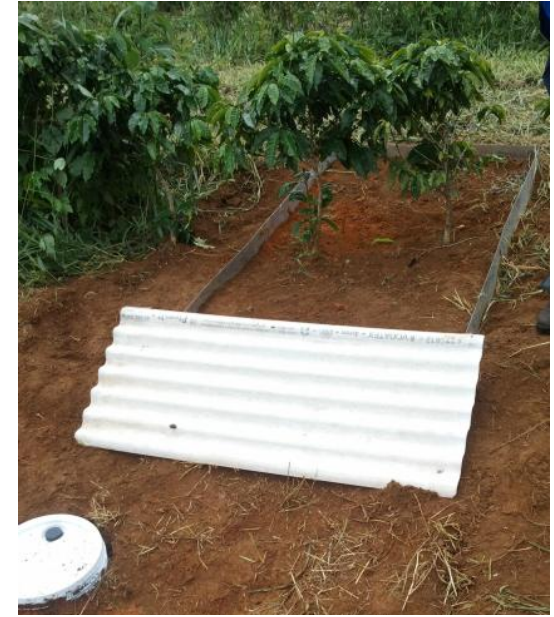

Figura 4.3 - Parcelas de erosão no Cultivo de Café.

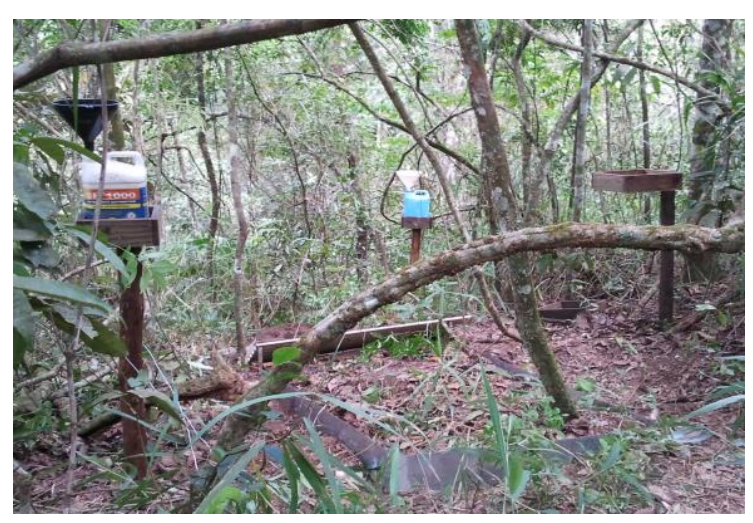

Figura 4.5 - Parcela de Erosão na Mata de Galeria.

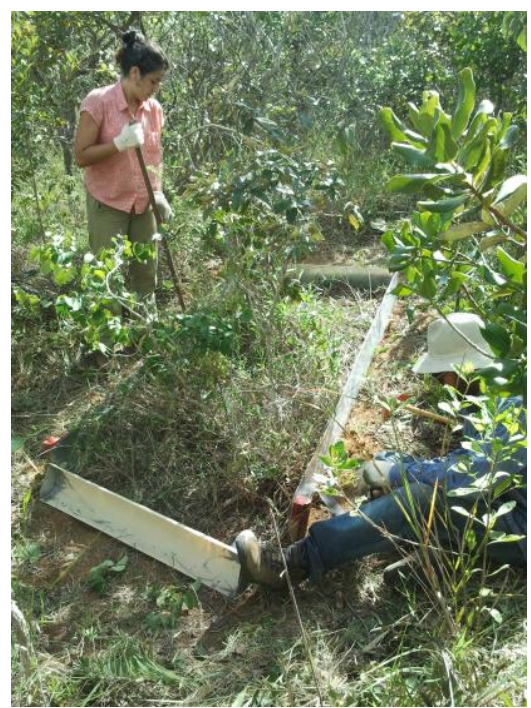

Figura 4.6 - Parcela de erosão no Cerrado - fase de instalação.

\section{RESULTADOS E DISCUSSÕES}

Análise do Solo 
Para a análise granulométrica, foram coletadas amostras de solo do canto superior direito externo de cada parcela de erosão. O resultado da análise granulométrica está contido na Tabela 4.1.

Tabela 4.1 - Distribuição granulométrica dos solos das parcelas.

\begin{tabular}{|c|c|c|c|c|c|c|}
\hline Uso do Solo & Parcela & $\%$ Areia & \% Silte & $\%$ Argila & Textura & Classe de solo \\
\hline \multirow{3}{*}{ Mata de Galeria } & P1 & $12,90 \%$ & $46,68 \%$ & $40,42 \%$ & Argila Siltosa & Hidromórfico \\
\hline & $\mathrm{P} 2$ & $13,71 \%$ & $38,43 \%$ & $47,86 \%$ & Argiloso & Hidromórfico \\
\hline & P3 & $22,55 \%$ & $35,85 \%$ & $41,60 \%$ & Argiloso & Hidromórfico \\
\hline \multirow{3}{*}{ Cerrado } & $\mathrm{P} 4$ & $13,66 \%$ & $21,31 \%$ & $65,02 \%$ & Muito Argilosa & Latossolo Vermelho-Amarelo \\
\hline & P5 & $13,07 \%$ & $7,74 \%$ & $79,20 \%$ & Muito Argilosa & Latossolo Vermelho-Amarelo \\
\hline & P6 & $13,99 \%$ & $16,10 \%$ & $69,91 \%$ & Muito Argilosa & Latossolo Vermelho-Amarelo \\
\hline \multirow{3}{*}{ Café } & P7 & $13,37 \%$ & $20,52 \%$ & $66,11 \%$ & Muito Argilosa & Latossolo Vermelho-Amarelo \\
\hline & P8 & $19,20 \%$ & $36,67 \%$ & $44,13 \%$ & Argiloso & Latossolo Vermelho-Amarelo \\
\hline & P9 & $8,69 \%$ & $11,73 \%$ & $79,58 \%$ & Muito Argilosa & Latossolo Vermelho-Amarelo \\
\hline \multirow{3}{*}{ Gramínea } & $\mathrm{P} 10$ & $18,61 \%$ & $11,07 \%$ & $70,32 \%$ & Muito Argilosa & Latossolo Vermelho \\
\hline & P11 & $19,22 \%$ & $1,70 \%$ & $79,07 \%$ & Muito Argilosa & Latossolo Vermelho \\
\hline & P12 & $21,30 \%$ & $8,01 \%$ & $70,69 \%$ & Muito Argilosa & Latossolo Vermelho \\
\hline \multirow{3}{*}{ Solo Exposto } & P13 & $23,19 \%$ & $6,00 \%$ & $70,82 \%$ & Muito Argilosa & Latossolo Vermelho \\
\hline & P14 & $14,99 \%$ & $9,79 \%$ & $75,22 \%$ & Muito Argilosa & Latossolo Vermelho \\
\hline & P15 & $16,82 \%$ & $12,86 \%$ & $70,32 \%$ & Muito Argilosa & Latossolo Vermelho \\
\hline
\end{tabular}

Fonte: Metodologia Reatto, 2004. Granulometria realizada pela autora e estagiários do Lagef.

Embora o mapa de localização da área de trabalho (Figura 4.1) que contém as classes de solo de cada estação, aponte que o Cerrado esteja em solo hidromórfico, a granulometria mostrou que se trata de um Latossolo Vermelho-Amarelo. O café também está sob este mesmo tipo de solo, ambos margeando a Mata de Galeria do Córrego Capetinga. Segundo Reatto (2004), o Cerrado stricto sensu é a fitofisionomia associada a esta classe de solo. Os Latossolos Vermelhos-Amarelos e os Latossolos Vermelhos têm as mesmas propriedades, diferenciando-se somente pela cor. Estas classes de solo têm por característica serem profundos, chegando a $300 \mathrm{~cm}$, com alta porosidade, bem drenados e bastante permeáveis (EMBRAPA, 1978). Apesar de bem drenados e pouco suscetíveis à erosão, os latossolos trabalhados na pesquisa quando foram expostos, tiveram incremento considerável de perda de sedimentos, como foi o caso das parcelas de Solo Exposto e do Café. Os resultados da tensiometria (dispostos adiante) puderam demonstrar a capacidade de infiltração dos latossolos. 
As parcelas da Mata de Galeria estão sobre solo hidromórfico indiscriminado, que tem por característica ter se desenvolvido sob forte influência das variações sazonais do nível do lençol freático. Apresentam alto teor de matéria orgânica parcial ou totalmente decomposta, horizontes superficiais orgânico-minerais e camadas acinzentadas (característica de gleização). Tem permeabilidade lenta e são pouco profundos, além de baixa porosidade (EMBRAPA, 1978).

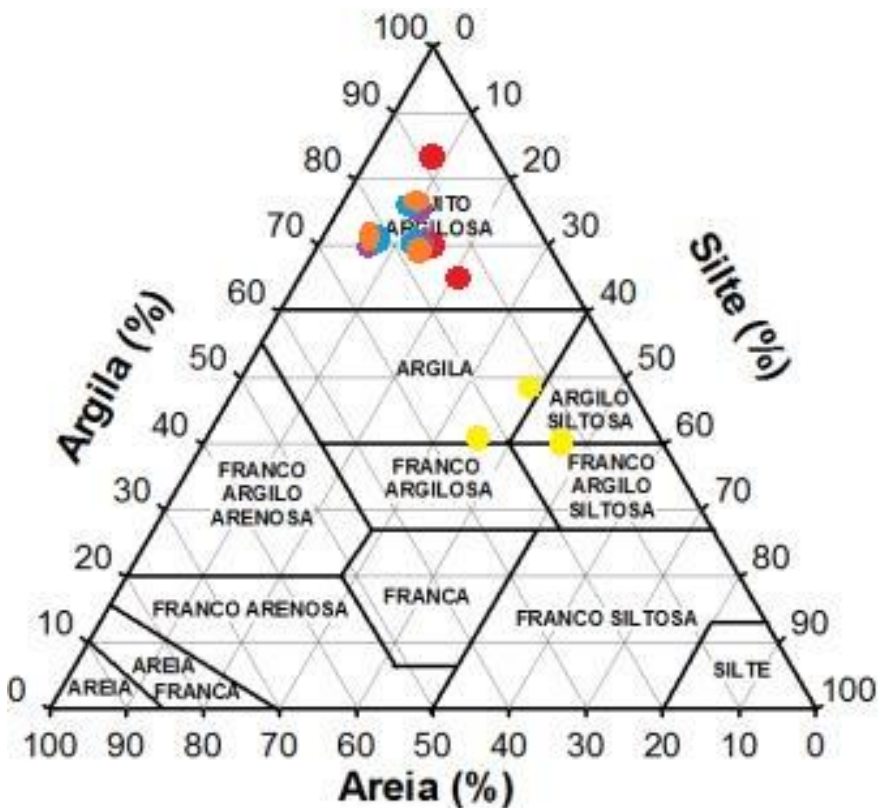

Figura 4.7 - Triângulo de textura do solo

Legenda: Amarelo - Mata de Galeria; Vermelho - Café; Lilás - Cerrado; Laranja - solo Exposto; Azul Gramínea.

A Figura 4.7 representa o triângulo de textura do solo das parcelas. As parcelas das estações Cerrado, Café, Gramínea e Solo Exposto possuem granulometria bastante semelhante, situando-se na área do gráfico "Silto Argilosa", que correspondente à granulometria "Muito Argiloso". As parcelas da estação Mata de Galeria encontram-se na área do gráfico "Argila" e "Argilo Siltosa" devido menor proporção de argila e maior proporção da fração silte, em relação ao solo das demais parcelas.

\section{Entra de água no sistema: precipitação pluviométrica}

O período de coleta de dados de pluviometria e escoamento superficial foi do dia 10 de dezembro de 2014 a 27 de abril de 2015. Sendo que dos dias 17 a 22 dezembro não houve coleta devido a ajustes nas parcelas. O total precipitado registrado pelo pluviômetro CAP 01 foi de $721,8 \mathrm{~mm}$, e pela estação pluvio-fluvio FAL-UNB foi de 719,6 mm, como pode ser visto nas Tabela 4.2 e Tabela 4.3. Ocorreram 310 eventos pluviométricos, variando de $0,2 \mathrm{~mm}$ 
a 78,6 mm, e com intensidades entre 0,2 e $55,6 \mathrm{~mm} / \mathrm{h}$, dados registrados pelo pluviômetro CAP 01; e 283 eventos, variando entre $0,2 \mathrm{~mm}$ e 46,4 $\mathrm{mm}$, e intensidades entre 0,2 e 46,4 $\mathrm{mm} / \mathrm{h}$, registrado no pluviômetro FAL-UNB. O dia em que se registrou a maior precipitação acumulada, além de maior intensidade, foi $1^{\circ}$ março, com total de 78,6 e $84,2 \mathrm{~mm}$, respectivamente para os dois pluviômetros, sendo 9 horas de chuva. Durante o período de coleta, houve um intervalo de estiagem de 17 dias consecutivos entre 04 e 20 de janeiro de 2015. No mês de fevereiro houve estiagem de 7 dias.

Tabela 4.2 - Períodos de coleta, Precipitação acumulada do período, Número de dias do período, Número de dias com chuva, Classes de chuva - Pluviômetro CAP 01.

\begin{tabular}{|c|c|c|c|c|c|c|c|c|}
\hline \multirow[b]{2}{*}{ Coleta } & \multirow[b]{2}{*}{ Período } & \multirow{2}{*}{$\begin{array}{l}\text { Precipitação } \\
\text { Acumulada } \\
(\mathrm{mm})\end{array}$} & \multirow[b]{2}{*}{$\begin{array}{c}\mathrm{N}^{\circ} \text { dias do } \\
\text { período }\end{array}$} & \multirow[b]{2}{*}{$\begin{array}{c}\mathrm{N}^{\mathrm{o}} \text { dias } \\
\text { de chuva }\end{array}$} & \multicolumn{4}{|c|}{ Intensidade - Classes de Chuva } \\
\hline & & & & & $\begin{array}{c}0,2 \text { a } 10 \\
\mathrm{~mm} / \mathrm{h}\end{array}$ & $\begin{array}{c}10,2 \text { a } 20 \\
\mathrm{~mm} / \mathrm{h}\end{array}$ & $\begin{array}{c}20,2 \text { a } 50 \\
\mathrm{~mm} / \mathrm{h}\end{array}$ & $\begin{array}{c}>50 \\
\mathrm{~mm} / \mathrm{h}\end{array}$ \\
\hline $1^{\mathrm{a}}$ & $10-16 / 12 / 14$ & 36,4 & 6 & 5 & 18 & 1 & 0 & 0 \\
\hline $2^{\mathrm{a}}$ & $\begin{array}{c}24 / 12 / 14- \\
09 / 01 / 15 \\
\end{array}$ & 4,4 & 16 & 3 & 9 & 0 & 0 & 0 \\
\hline $3^{\mathrm{a}}$ & $09-24 / 01 / 15$ & 41,8 & 15 & 3 & 14 & 0 & 1 & 0 \\
\hline $4^{\mathrm{a}}$ & $24-30 / 01 / 15$ & 55,6 & 6 & 6 & 14 & 1 & 1 & 0 \\
\hline $5^{\mathrm{a}}$ & $\begin{array}{c}30 / 01- \\
09 / 02 / 15 \\
\end{array}$ & 104,2 & 10 & 6 & 46 & 0 & 0 & 0 \\
\hline $6^{\mathrm{a}}$ & $\begin{array}{c}09 / 02- \\
09 / 03 / 15 \\
\end{array}$ & 169,2 & 28 & 11 & 32 & 4 & 1 & 0 \\
\hline $7^{\mathrm{a}}$ & $09-16 / 03 / 15$ & 70,8 & 7 & 6 & 38 & 2 & 0 & 0 \\
\hline $8^{a}$ & $16-23 / 03 / 15$ & 70,4 & 7 & 6 & 44 & 2 & 0 & 0 \\
\hline $9^{a}$ & $23-30 / 03 / 15$ & 33,4 & 8 & 4 & 8 & 2 & 0 & 0 \\
\hline $10^{\mathrm{a}}$ & $\begin{array}{c}30 / 03- \\
06 / 04 / 15 \\
\end{array}$ & 42,4 & 7 & 5 & 13 & 1 & 0 & 0 \\
\hline $11^{\mathrm{a}}$ & $06-13 / 04 / 15$ & 35,4 & 7 & 4 & 11 & 1 & 0 & 0 \\
\hline $12^{\mathrm{a}}$ & $13-27 / 04 / 15$ & 55,6 & 14 & 9 & 46 & 0 & 0 & 0 \\
\hline TOTAL & $\begin{array}{c}10 / 12 / 14- \\
27 / 04 / 15 \\
\end{array}$ & 719,6 & 131 & 68 & 293 & 14 & 3 & 0 \\
\hline
\end{tabular}

Tabela 4.3 - Períodos de coleta, Precipitação acumulada do período, Número de dias do período, Número de dias com chuva, Classes de chuva - Pluviômetro FAL-UNB

\begin{tabular}{|c|c|c|c|c|c|c|c|c|}
\hline \multirow[b]{2}{*}{ Coleta } & \multirow[b]{2}{*}{ Período } & \multirow{2}{*}{$\begin{array}{l}\text { Precipitação } \\
\text { Acumulada } \\
\text { (mm) }\end{array}$} & \multirow[b]{2}{*}{$\begin{array}{c}\mathrm{N}^{\mathrm{o}} \text { dias do } \\
\text { período }\end{array}$} & \multirow[b]{2}{*}{$\begin{array}{l}\mathrm{N}^{\mathrm{o}} \text { dias } \\
\text { de chuva }\end{array}$} & \multicolumn{4}{|c|}{ Intensidade - Classes de Chuva } \\
\hline & & & & & $\begin{array}{c}0,2 \text { a } 10 \\
\mathrm{~mm} / \mathrm{h}\end{array}$ & $\begin{array}{c}10,2 \text { a } 20 \\
\mathrm{~mm} / \mathrm{h}\end{array}$ & $\begin{array}{c}20,2 \text { a } 50 \\
\mathrm{~mm} / \mathrm{h}\end{array}$ & $\begin{array}{c}>50 \\
\mathrm{~mm} / \mathrm{h}\end{array}$ \\
\hline $1^{\mathrm{a}}$ & $\begin{array}{c}10- \\
16 / 12 / 14\end{array}$ & 28,2 & 6 & 5 & 16 & 0 & 0 & 0 \\
\hline $2^{\mathrm{a}}$ & $\begin{array}{c}24 / 12 / 14- \\
09 / 01 / 15\end{array}$ & 6 & 16 & 3 & 7 & 0 & 0 & 0 \\
\hline $3^{\mathrm{a}}$ & $09-24 / 01 / 15$ & 47,6 & 15 & 3 & 12 & 0 & 1 & 0 \\
\hline $4^{\mathrm{a}}$ & $24-30 / 01 / 15$ & 70,4 & 6 & 5 & 14 & 2 & 1 & 0 \\
\hline $5^{\mathrm{a}}$ & $\begin{array}{c}30 / 01- \\
09 / 02 / 15 \\
\end{array}$ & 87,8 & 10 & 6 & 44 & 0 & 0 & 0 \\
\hline $6^{\mathrm{a}}$ & $\begin{array}{c}09 / 02- \\
09 / 03 / 15 \\
\end{array}$ & 198 & 28 & 13 & 51 & 2 & 3 & 0 \\
\hline $7^{\mathrm{a}}$ & $09-16 / 03 / 15$ & 92,6 & 7 & 6 & 31 & 0 & 2 & 0 \\
\hline $8^{\mathrm{a}}$ & $16-23 / 03 / 15$ & 59 & 7 & 6 & 35 & 0 & 2 & 0 \\
\hline $9^{a}$ & $23-30 / 03 / 15$ & 11,4 & 7 & 4 & 5 & 1 & 0 & 0 \\
\hline $10^{\mathrm{a}}$ & $30 / 03-$ & 14 & 7 & 4 & 15 & 0 & 0 & 0 \\
\hline
\end{tabular}




\begin{tabular}{c|c|c|c|c|c|c|c|c}
\hline & $06 / 04 / 15$ & & & & & & & \\
\hline $11^{\mathrm{a}}$ & $06-13 / 04 / 15$ & 48,2 & 7 & 6 & 11 & 2 & 0 & 0 \\
\hline $12^{\mathrm{a}}$ & $13-27 / 04 / 15$ & 55,2 & 14 & 8 & 26 & 1 & 0 & 0 \\
\hline TOTAL & $\begin{array}{c}\mathbf{1 0 / 1 2 / 1 4 -} \\
\mathbf{2 7 / 0 4 / 1 5}\end{array}$ & $\mathbf{7 1 8 , 4}$ & $\mathbf{1 3 0}$ & $\mathbf{6 9}$ & $\mathbf{2 6 7}$ & $\mathbf{8}$ & $\mathbf{9}$ & $\mathbf{0}$ \\
\hline
\end{tabular}

O pluviômetro CAP 01 registrou volume maior de precipitação, mais dias de chuva, e mais eventos dentro da classe entre 10,2 e $20 \mathrm{~mm}$. Porém, o pluviômetro FAL-UNB registrou maior ocorrência de chuvas com intensidade dentro da classe entre 20,2 e $50 \mathrm{~mm} / \mathrm{h}$.

Os valores da precipitação registrados no pluviômetro CAP 01 foram inseridos em um gráfico de correlação com a média dos dados registrados nos pluviômetros artesanais instalados na MG e no CE (Figura 4.8 A e B). Pode-se ver que há ótima correlação $\left(\mathrm{R}^{2}=\right.$ 0,9727 e $\mathrm{R}^{2}=0,9681$, respectivamente) entre o aumento da precipitação e o atravessamento. $\mathrm{O}$ aumento do atravessamento significa incremento de umidade na camada de serapilheira, no solo, e maior possibilidade escoamento superficial.
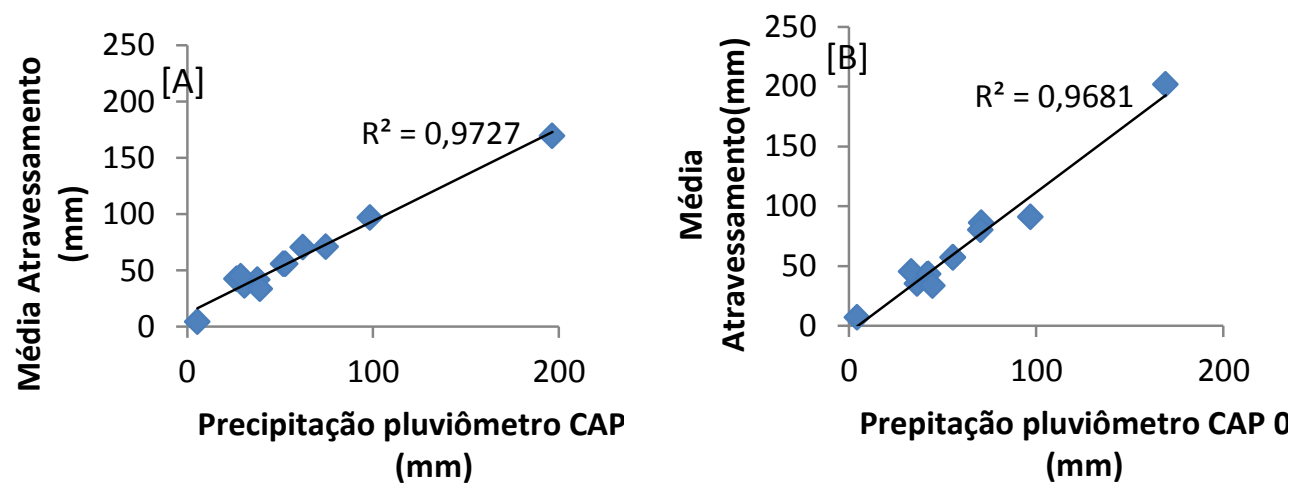

Figura 4.8 - Gráfico de correlação entre precipitação do pluviômetro CAP 01 e o fluxo de atravessamento médio medido pelos pluviômetros artesanais da Mata de Galeria [A] e Cerrado [B].

A Figura 4.9 é o gráfico da razão escoamento superficial (Q) e a precipitação. Os valores encontrados nas parcelas da MG variaram entre 1,3 e 2,1\%, sendo esperado que neste uso o escoamento superficial fosse mais baixo, devido à alta capacidade de absorção de umidade pela serrapilheira. O solo é bem drenado em decorrência da concentração de matéria orgânica, por causa da malha de raízes e pelo canal de drenagem ser bastante dissecado. $\mathrm{Na}$ parcela P2 geralmente havia mais amostra de escoamento superficial do que nas demais da mesma estação. Em seu interior havia uma árvore com mais de 3 metros de altura e mais de $50 \mathrm{~cm}$ de diâmetro à altura do peito. Pode ter havido contribuição do fluxo de tronco concentrado, aumentando o escoamento superficial desta parcela. Na coleta do dia 30 de janeiro de 2015, a parcela P3 apresentou amostra com valor discrepante das demais coletas e das demais parcelas da MG da mesma coleta. No dia 25 de janeiro de 2015 foi registrada 
precipitação de 34,8 mm (CAP 01), e mudança na direção dos ventos. Em frente à P3, há uma clareira que pode ter favorecido o incremento deste escoamento superficial específico.

A razão do escoamento superficial com a precipitação no Cerrado variou mais do que na MG (de 2,1 a 4,1\%) porque a camada de serrapilheira é menos espessa, e porque o dossel é menor, aumentando a quantidade de precipitação que atinge a superfície, e diminuindo a capacidade de absorção da umidade. A parcela P5 apresentou um valor de escoamento bastante superior do que as demais parcelas do Cerrado, totalizando 81,22 L, enquanto que P4 e P6 totalizaram 17,54 L e 14,94 L. Sobre P5 havia folhas da copa de um arbusto. A precipitação interceptada pelo arbusto teria concentrado o fluxo em direção à parcela. Sato (2011) explica que a arquitetura do dossel e dos ramos determina até certo ponto se o volume interceptado irá gotejar ou escoar pelo tronco.

No uso do CF, a razão variou entre 4,5 e $8 \%$, bem superior do que na $\mathrm{MG}, \mathrm{C}$ e GR. Isso deve à forma em que os pé de café são plantados: na linha do plantio, o solo fica exposto, e somente entre as linhas existe gramínea; ou seja, a parte em que não há cobertura do solo, favorece o escoamento superficial. Houve variação nos valores nos volumes de escoamento desta estação, onde se esperava que fossem maiores do que realmente foram. A gramínea existente entre as linhas por vezes ficou bem alta, o que influenciou no escoamento superficial das parcelas, absorvendo a água e criando obstáculo.

$\mathrm{Na}$ estação GR, houve uma variação entre 0,4 e $6 \%$. Possivelmente, a parcela P12 deveria ter um arranjo distinto da malha das raízes, ou diferir no perfil do solo, pois seus valores foram bastante superiores do que os das parcelas P10 e P11.

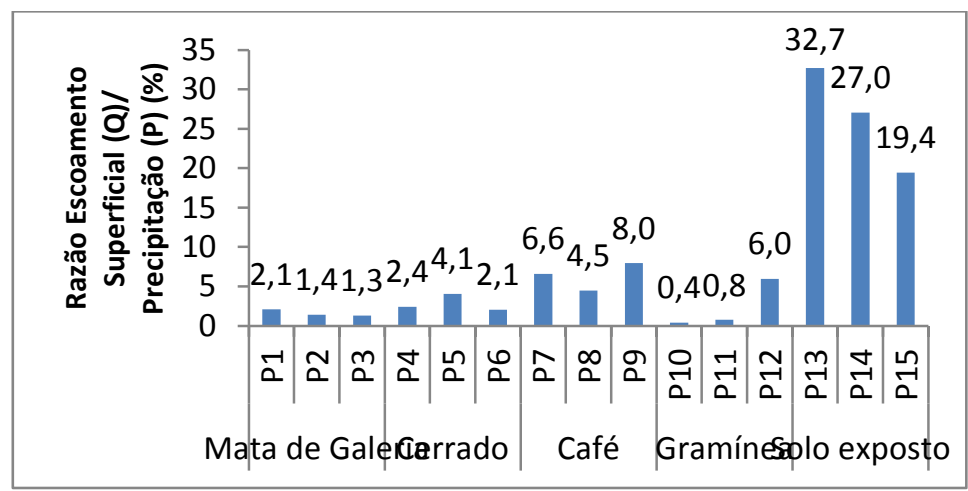

Figura 4.9 - Gráfico da Razão Escoamento Superficial (Q) e Precipitação (mm) das parcelas de erosão por tipo de uso do solo - \%

$\mathrm{O}$ escoamento superficial ocorrido em SE foi mais que o dobro daquele ocorrido nas demais parcelas dos outros usos. Os dados variaram entre 19,4 e 32,7\%. Esta variação é 
explicada pelo fato de que, depois de aplicado o Glifosato, os resquícios de raiz da gramínea que existiam dentro das parcelas, foram retirados primeiro em P13. Em P14 e P15 foram retiradas em tempo posterior. Além disso, foram necessários alguns ajustes nas parcelas que estavam apresentando vazamentos. Somente após estes acontecimentos é que os valores das três parcelas de SE ficaram semelhantes.

Foi na estação SE que os reservatórios foram cheios até sua capacidade máxima, na $6^{\mathrm{a}}$ e $7^{\text {a }}$ coleta, realizadas nos dias 09 e 16 de março de 2015. O período da coleta número 6, foram 28 dias, com apenas 13 dias de chuva. Grande parte dos eventos pluviométricos foram de baixa, de média, e de alta intensidade. As chuvas de alta intensidade ocorreram em dias próximos, fornecendo umidade ao solo, um dos fatores que pode explicar o volume grande escoamento superficial, e também de sedimentos transportados (Veja Erro! Fonte de referência não encontrada.).

As Figura 4.10 e Figura 4.11 são gráficos compostos que trazem os valores de escoamento superficial e de produção de sedimentos de parcela, por tipo de uso do solo, associados aos dados de precipitação diária, precipitação acumulada no período de coleta e a intensidade diária (razão do acumulado do dia pelo número de horas de chuva). Na precipitação acumulada onde aparece um pico, e logo em seguida, um declínio até zero, o declínio representa o dia da coleta.

As parcelas da MG mostraram pouca variação em seus valores, sendo que os maiores valores ocorreram nas coletas dos dias 30/01/2015 e 09/03/2015. Na primeira, houve precipitação acumulada de 55,6 mm, e intensidades que variaram entre 5 e 7,6 mm/h. neste período, houve chuvas todos os dias. Na segunda coleta, houve dois eventos de alta intensidade, além de precipitação acumulada alta e 3 dias de precipitação consecutivos. 

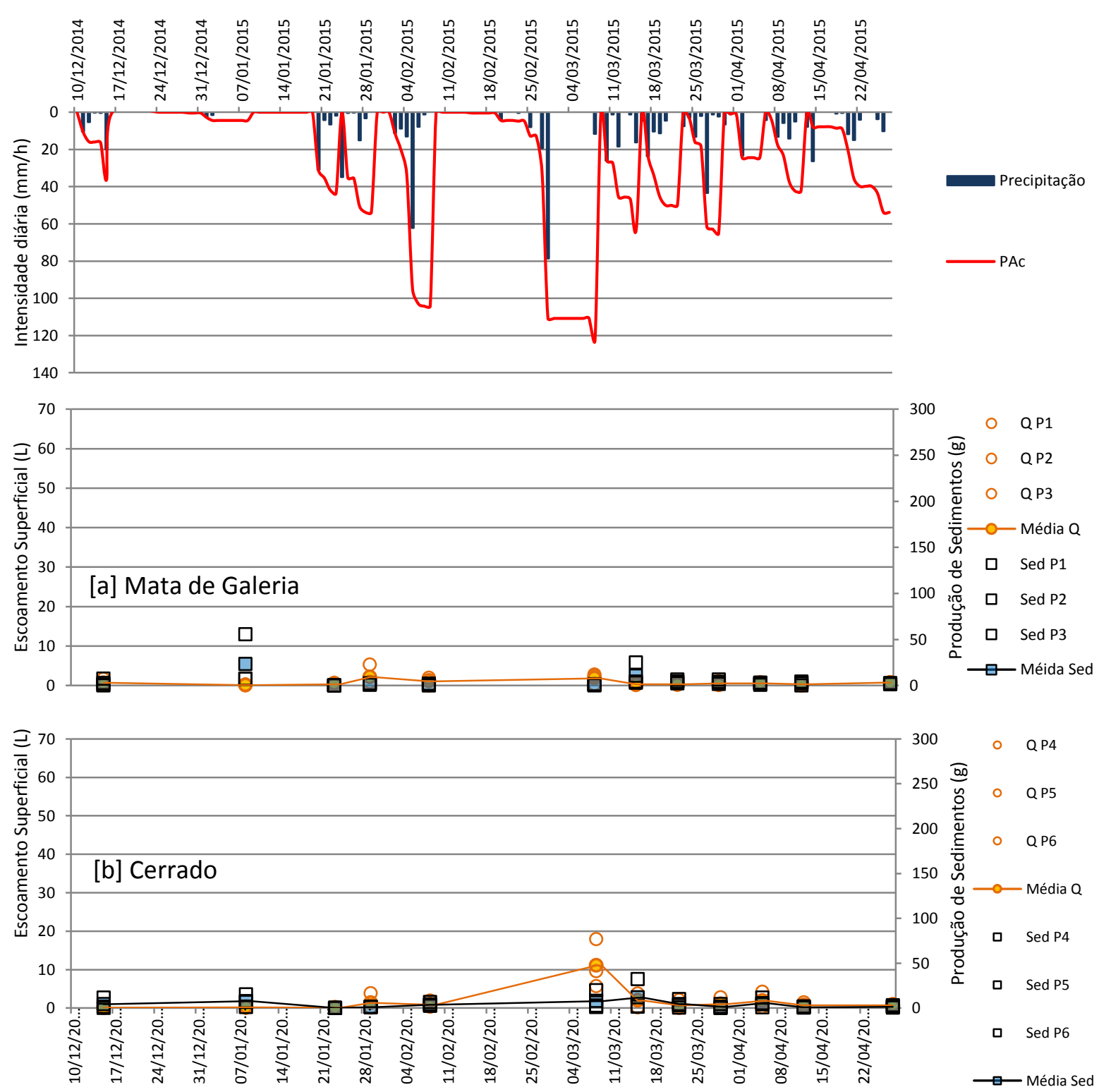

Figura 4.10 - Gráfico Relação Precipitação Diária, Precipitação Acumulada do período da coleta, Intensidade Diária $(\mathrm{mm} / \mathrm{h})$ - pluviômetro CAP 01, Escoamento Superficial e Produção de Sedimentos Estações Mata de Galeria [a] e Cerrado [b]. A seta em vermelho representa um conjunto de amostras que foram perdidas durante o processo de análise, referentes à coleta do dia 24/01/2015.

As mesmas coletas que geraram maior escoamento superficial em GR, também geraram maior escoamento em CE. Porém, houve coletas com menor escoamento, mas que geraram maior produção de sedimentos, tais como a primeira coleta, a segunda, a sétima e a décima. Houve uma variação significativa na relação escoamento superficial x produção de sedimentos entre as parcelas do Cerrado. A parcela P4 produzia menos escoamento em relação à P5, porém havia maior concentração de sedimentos g/L. A parcela P5 sempre produzia um volume maior de escoamento, em relação à duas outras parcelas, mas baixa concentração de sedimentos. A parcela P6 foi instalada em local com maior declividade do que P4 e P5, porém o escoamento superficial e perda sedimentar eram menores. 

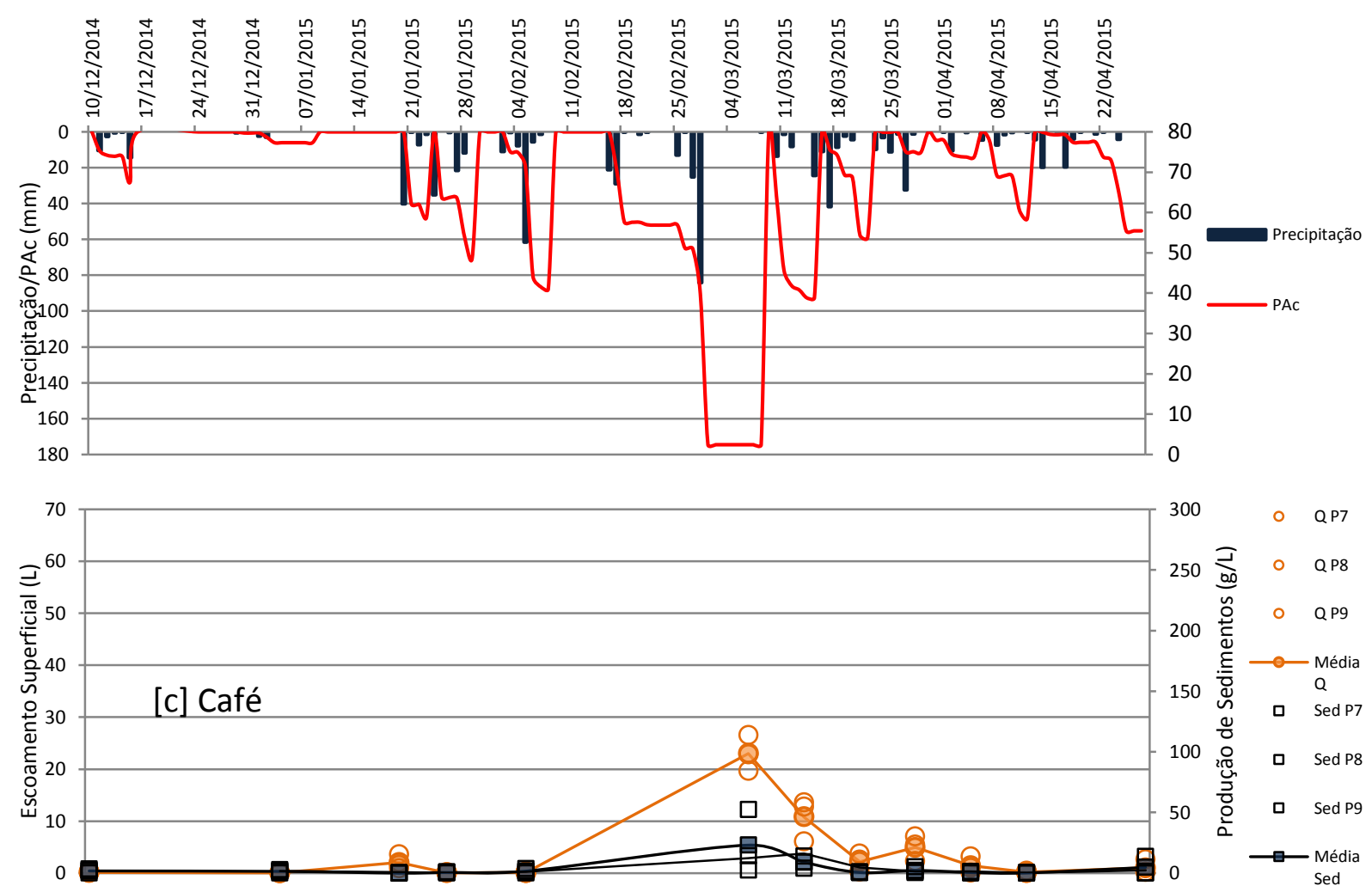

Q QP7
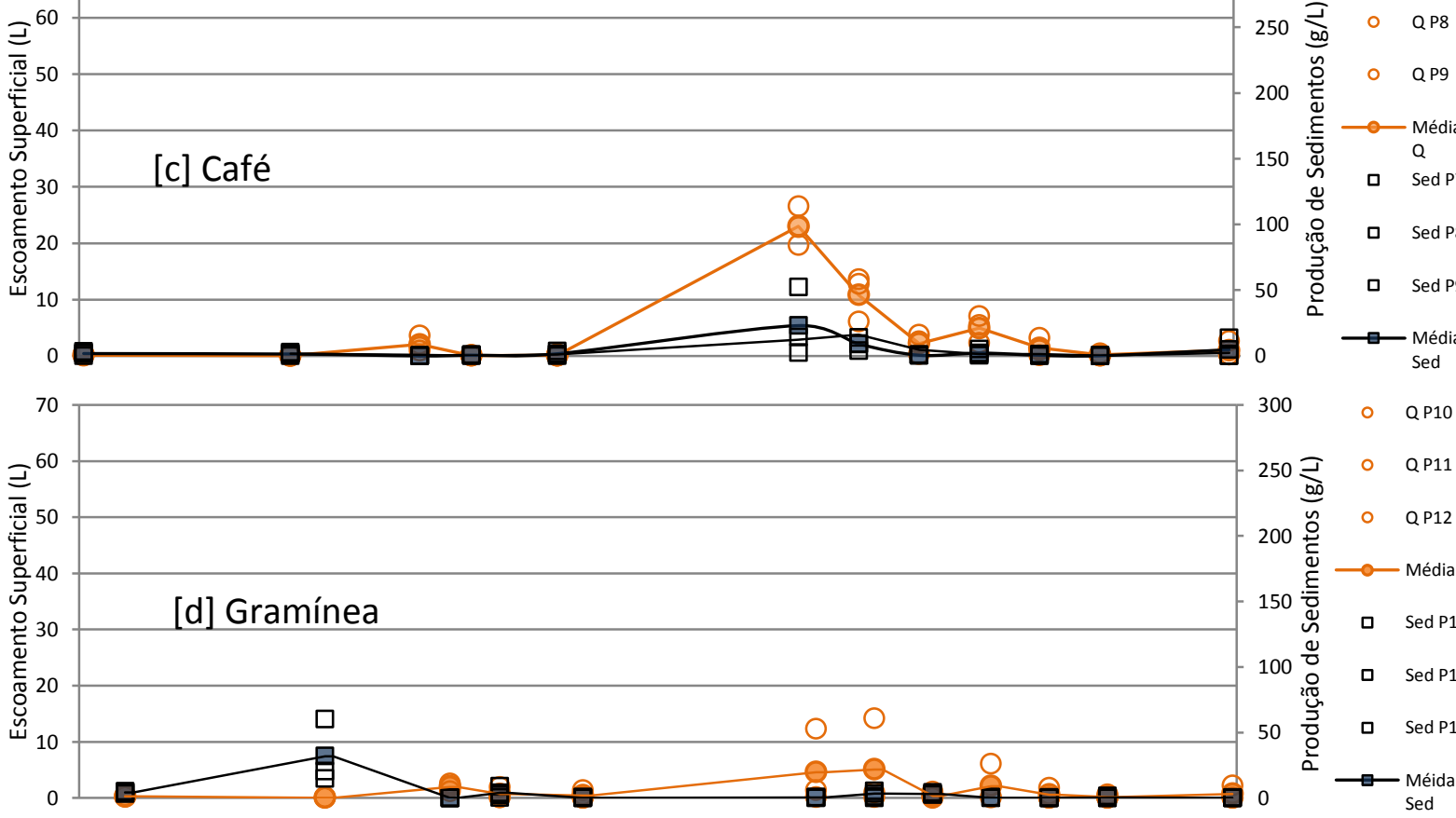

E —-Média

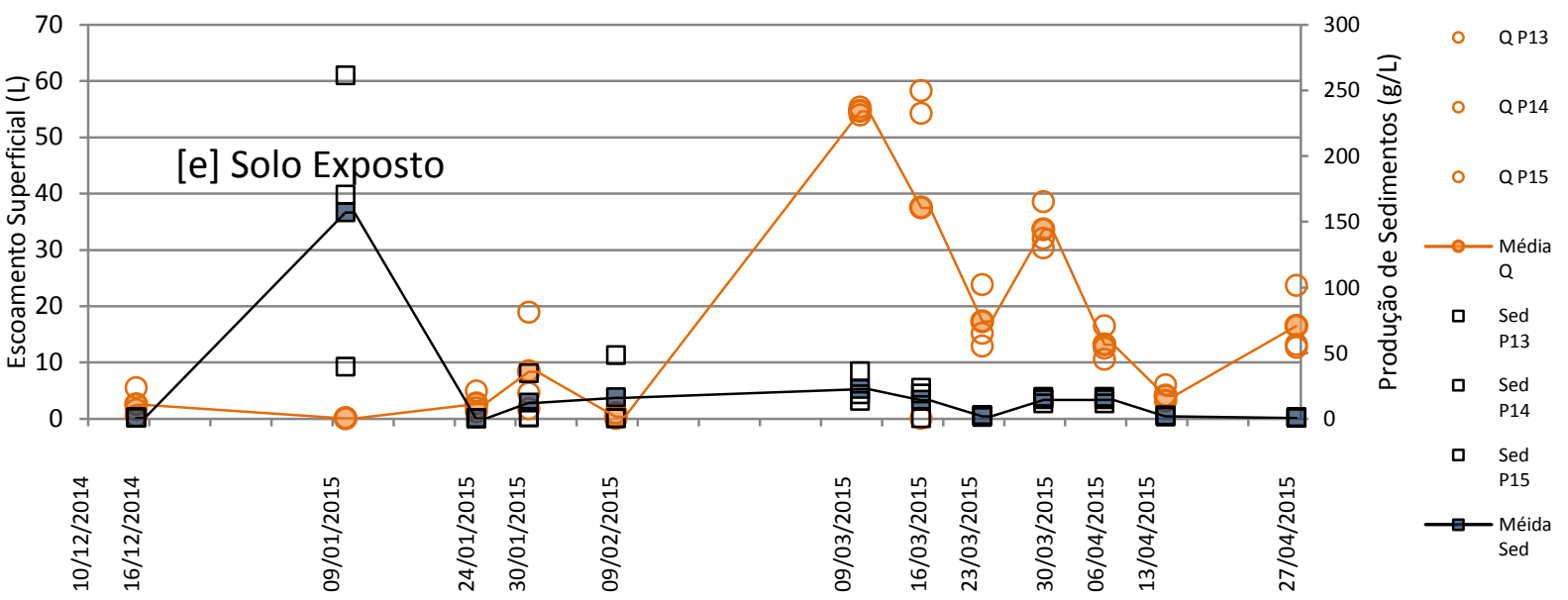

Figura 4.11 - Gráfico Relação Precipitação Diária, Precipitação Acumulada por período de coleta, Intensidade Diária $(\mathrm{mm} / \mathrm{h})$ - pluviômetro FAL-UNB, Escoamento Superficial e Produção de Sedimentos Estações [c] Café, [d] Gramínea e [e] Solo Exposto. 
As parcelas do Café responderam muito bem aos eventos ocorridos durante o período da coleta do dia 09/03/15, com escoamento variando entre 20 e 30 L, e concentração de sedimentos entre 4 e 18 g/L (Figura 4.9). A coleta do dia 16/3/15 mostrou também boa resposta de escoamento e erosão, mesmo com a diferença entre eventos ocorridos para a coleta anterior, tanto de volume de chuva, quanto o espaçamento entre elas. Para as coletas realizadas nos dias 16/12/14 e 09/01/15, percebe-se certa concentração de sedimentos, tendo em vista que o valor de escoamento foi bastante baixo. O mesmo ocorreu para as amostras coletadas nos dias 6 e 13/4/15, e para as parcelas da gramínea. As amostras coletadas no dia 30/3/15 mostram que houve um bom escoamento e produção de sedimentos para eventos pluviométricos de altura variando entre $\sim 9$ e $41 \mathrm{~mm}$, em dias consecutivos, evidenciando escoamento superficial em decorrência da umidade antecedente.

As parcelas do Solo Exposto apresentaram valores para o escoamento superficial e produção sedimentos, geralmente, o dobro dos valores encontrados para as parcelas do Café que obtiveram valores altos com relação às demais parcelas dos outros usos, conforme pode ser visto na Figura 4.11. Os eixos Y do Solo Exposto tiveram que ser em escala diferenciada dos demais usos para que se pudessem melhor visualizar os resultados.

As amostras das coletas dos dias 09/3/15 e 16/3/15 ocuparam todo o volume do recipiente de armazenamento $(50 \mathrm{~L})$, mais uma vez evidenciando que o comportamento do escoamento superficial não está somente relacionado com altas intensidades, ou volume precipitado (a parcela P15 não estava funcionando quando da coleta do dia 16/3/15). A variável umidade antecedente atuou de forma fundamental para que os valores da coleta do dia 16 tenham sido semelhantes com a coleta anterior. Semelhante a isso, ocorreu nas amostras coletadas nos dia 30/1/15 e 06/4/15, onde dias consecutivos de precipitação, mantiveram o perfil do solo úmido.

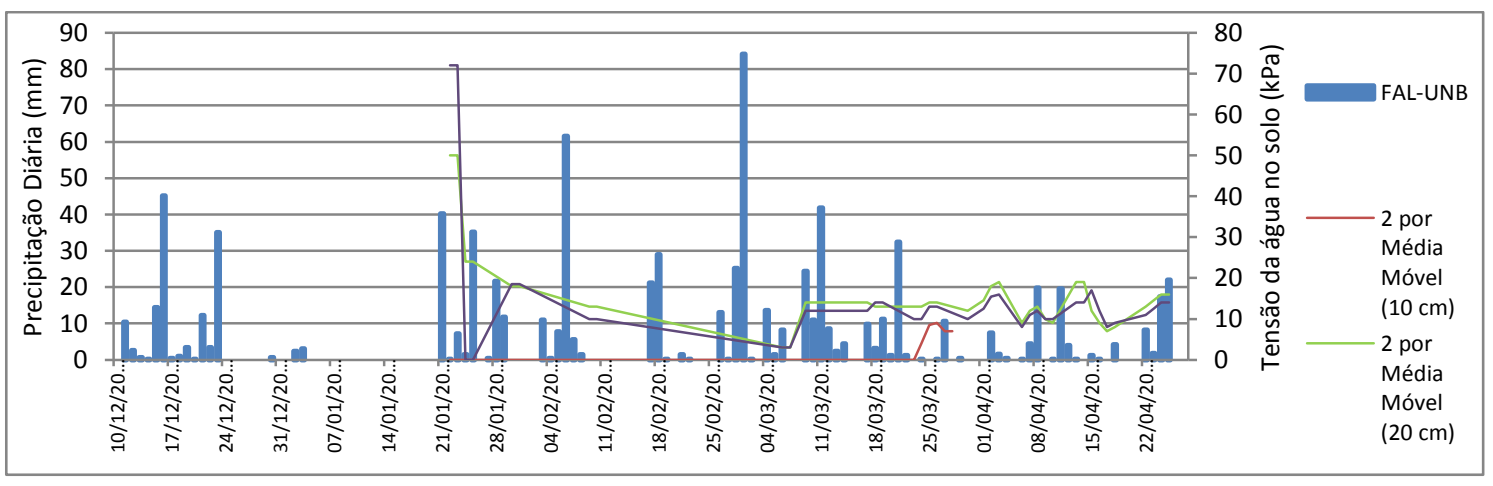

Figura 4.12 - Gráfico Relação Precipitação diária (mm) e Tensão da Água no Solo (kPa) - profundidades $10 \mathrm{~cm}, 20 \mathrm{~cm}$ e $45 \mathrm{~cm}$ - estação Mata de Galeria. 


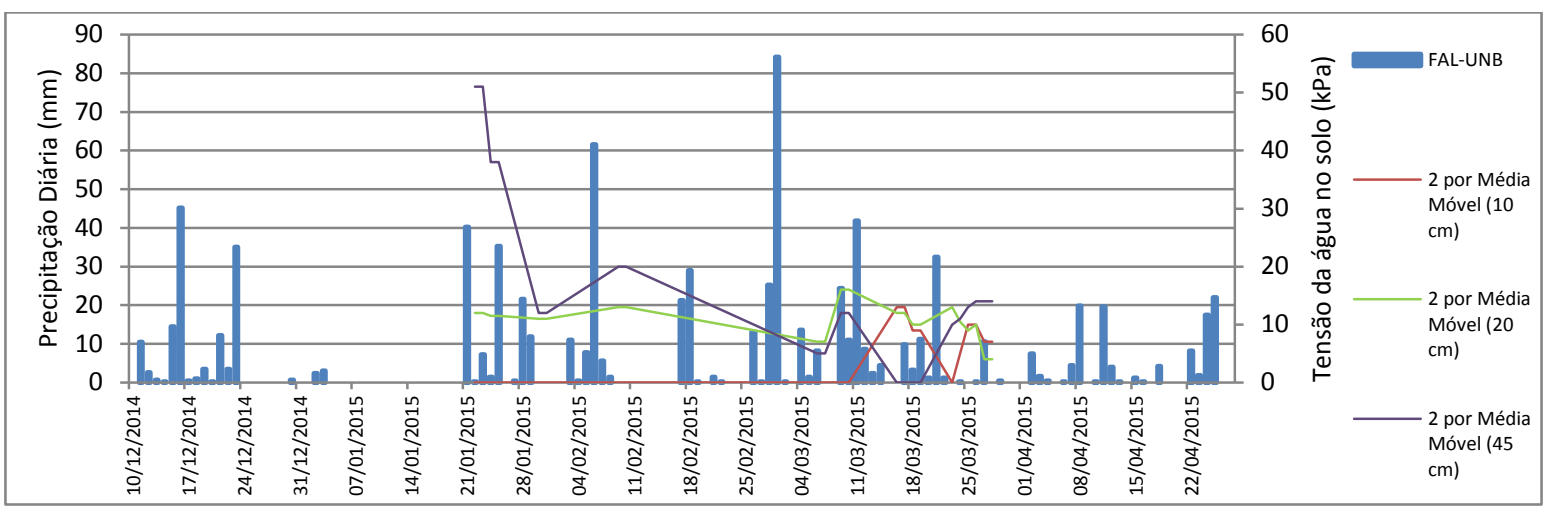

Figura 4.13 - Gráfico Relação Precipitação diária (mm) e Tensão da Água no Solo (kPa) - profundidades $10 \mathrm{~cm}, 20 \mathrm{~cm}$ e $45 \mathrm{~cm}$ - estação Cerrado.

A Figura 4.12 mostra a relação precipitação diária com a tensão da água no solo nas profundidades 10, 20 e $50 \mathrm{~cm}$, para a Mata de Galeria. Por problemas técnicos mencionados acima, o tensiômetro de $10 \mathrm{~cm}$ teve poucas leituras realizadas. Além disso, não havia uma pessoa que fizesse as leituras diárias por ser um lugar de difícil acesso. O mesmo aconteceu com a bateria de tensiômetros do Cerrado. Apesar da umidade existente na serrapilheira e das precipitações decorridas, a tensão da água na MG mostraram-se altas, chegando a mais de 20 cb em alguns momentos (Figura 4.13).

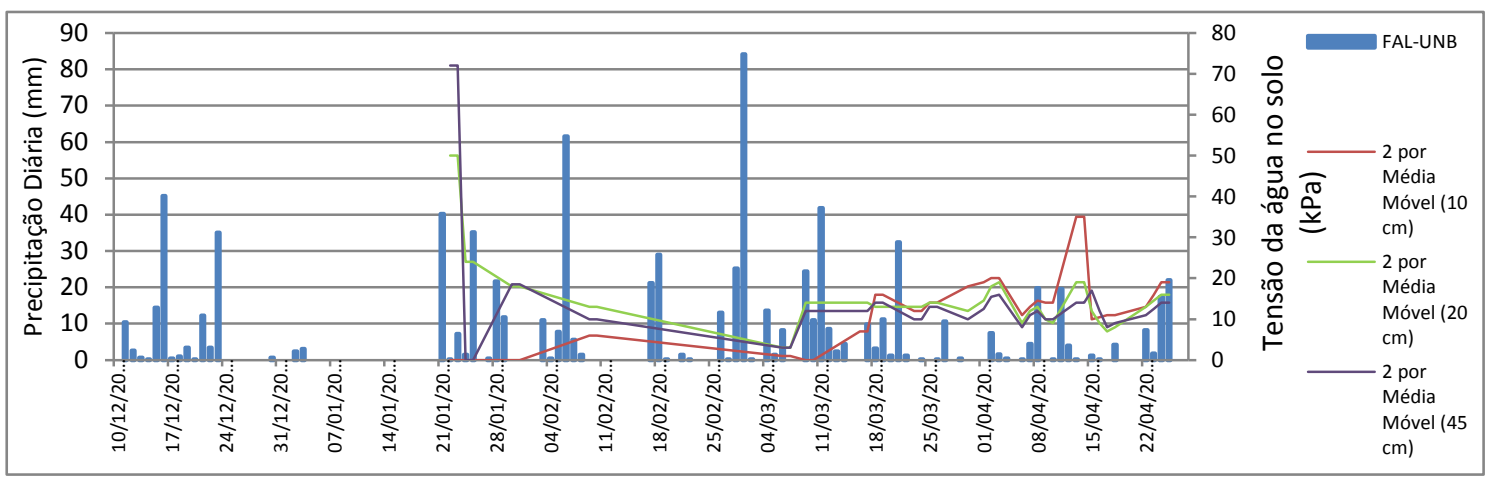

Figura 4.14 - Gráfico Relação Precipitação diária (mm) e Tensão da Água no Solo (kPa) - profundidades $10 \mathrm{~cm}, 20 \mathrm{~cm}$ e $45 \mathrm{~cm}$ - estação Café.

As tensões da água do solo para este uso variam pouco (entre 8 e $22 \mathrm{kPa}$ ) (), principalmente após a segunda quinzena de março. Os dados tensiométricos das primeiras leituras foi bastante alto a um grande período de estiagem. O solo estava bastante seco. $\mathrm{O}$ tensiômetro da profundidade de $10 \mathrm{~cm}$ também passou por uns dias sem funcionamento.

A Figura 4.11 evidenciou que as parcelas da Gramínea possuem uma resposta hidrológica bem distinta das parcelas do Café e do Solo Exposto, submetidas aos mesmos 
eventos pluviométricos. Tanto em relação à geração de escoamento superficial, quanto à perda de sedimentos. A amostra coletada no dia 09/3/15 teve resultados parecidos com aqueles obtidos no Cerrado na variável escoamento superficial, porém perdeu menos sedimentos.

Os dados da coleta do dia 09/01/15 mostraram uma alta produção de sedimentos, em comparação ao baixo escoamento. É possível que uma parte da água escoada tenha sido evaporada por causa da ausência de chuvas em parte do período entre esta coleta e a anterior, e devido às temperaturas máximas que variaram entre $24^{\circ}$ e $31,8^{\circ} \mathrm{C}(\mathrm{FAV}, 2014$ e 2015).

A Figura 4.15 traz os resultados da tensão da água no solo em função da precipitação. Mostra que houve grande variação da tensão, principalmente para a profundidade de $10 \mathrm{~cm}$, que chegou a $38 \mathrm{kPa}$ no mês de abril. Isso evidencia que a gramínea não foi capaz de manter a umidade na superfície, provavelmente, porque a água infiltrou no perfil. A tensão da profundidade $45 \mathrm{~cm}$ deixa isto bastante claro.

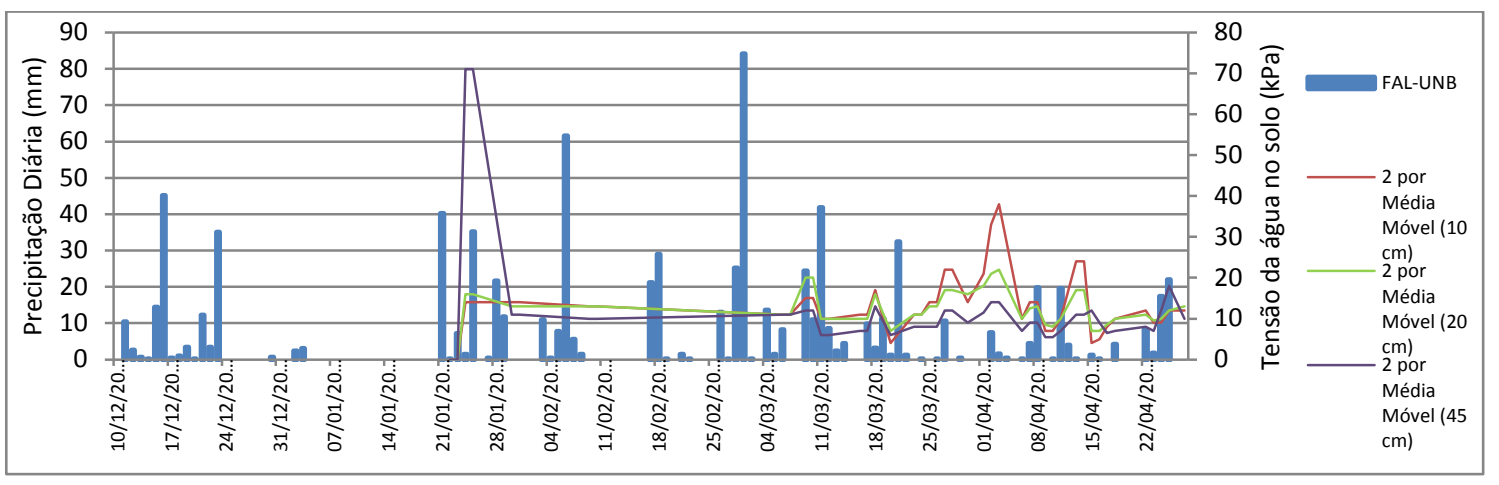

Figura 4.15 - Gráfico Relação Precipitação diária (mm) e Tensão da Água no Solo (kPa) - profundidades $10 \mathrm{~cm}, 20 \mathrm{~cm}$ e $45 \mathrm{~cm}$ - estação Gramínea.

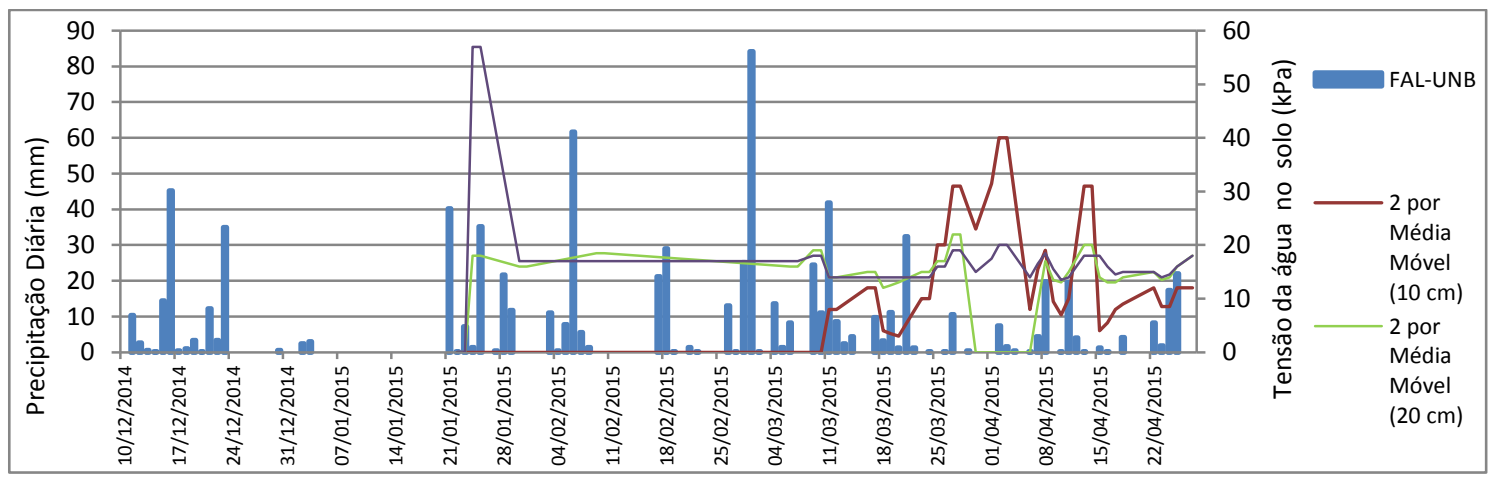

Figura 4.16 - Gráfico Relação Precipitação diária (mm) e Tensão da Água no Solo (kPa) - profundidades $10 \mathrm{~cm}, 20 \mathrm{~cm}$ e $45 \mathrm{~cm}$ - estação Solo Exposto.

A Figura 4.16 mostra a variação da tensão da água no solo em função da precipitação das parcelas do Solo Exposto. A tensão teve uma grande amplitude entre os valores mensurados, respondendo rapidamente à ocorrência e à ausência de precipitação, 
principalmente o tensiômetro de profundidade $10 \mathrm{~cm}$. Logo após a instalação dos tensiômetros, a água do tubo era rapidamente retida pelo solo, fazendo com que secasse. $\mathrm{O}$ tensiômetro de $20 \mathrm{~cm}$ teve uma boa resposta em relação aos eventos de chuva, tendo um comportamento de semelhante ao tensiomtero de $45 \mathrm{~cm}$. No período entre final de março e início de abril, a bomba do reservatório de água do tubo de $20 \mathrm{~cm}$ quebrou, não permitindo que se fizesse o vácuo necessário para medir a tensão. Depois de consertado, voltou a medir normalmente.

As Figuras Figura 4.14, Figura 4.15 e Figura 4.16 mostraram quão distinto é o comportamento hidrológico dos usos do solo ora investigados. A Figura 4.17 traz a distribuição dos valores coletados em cada parcela de erosão. Embora no mesmo uso do solo, o escoamento superficial pode ser distintos, como ocorreu nesta pesquisa. Para as parcelas da Mata de Galeria e do Cerrado, a cobertura do solo é diferente para cada uma delas.

Aquelas instaladas em MG sofreram influencia da interceptação, atravessamento e escoamento de tronco de forma distinta por causa da distribuição das plantas. Os valores mostrados na Figura 4.17 evidenciam esta variabilidade, principalmente no Máximo, Mínimo e $1^{\circ}$ Quartil.

No Cerrado, somente a parcela P5 sofria influencia de interceptação e atravessamento. A parcela P4 tinha mais gramínea e produzia menos escoamento do que P5. Os valores de escomento superficial do Cerrado variaram mais no $1^{\circ}$ Quartil. Como eixo Y está em escala logarítica para que a distribuição tivesse melhor representação, esta escala não mostra valores 0, que são os mínimos das 3 parcelas do CE, P1 da MG, as 3 do Cf, as 3 da GR e P13 e P15 de SE.

As parcelas do Café obtiveram os valores de Máximo, $3^{\circ}$ Quartil e Média bastante semelhantes, divergindo mais na Mediana, $1^{\circ}$ Quartil e Mínimo.

As parcelas da GR mostraram uma variação entre elas, onde P12 teve todos os valores, com exceção do Mínimo, acima de P10 e P11. É possível que haja um horizonte impermeável abaixo de P12, ou um arranjo distinto de sua malha de raízes.

O SE teveMáximo, $3^{\circ}$ Quartil e Média bem semelhantes entre as 3 parcelas, diferindo mais na Mediana por causa do Mínimo e do $1^{\circ}$ Quartil, que também variaram muito. 


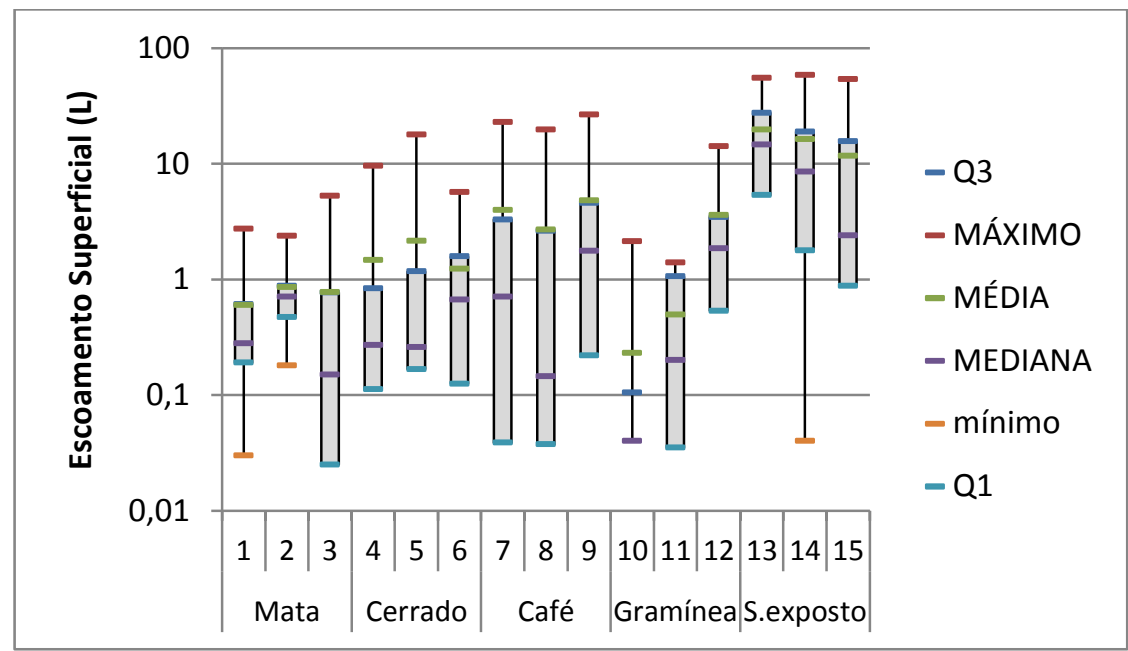

Figura 4.17 - Gráfico de Caixa com a distribuição dos valores do escoamento superficial (L) por parcela de erosão, por tipo de uso do solo.

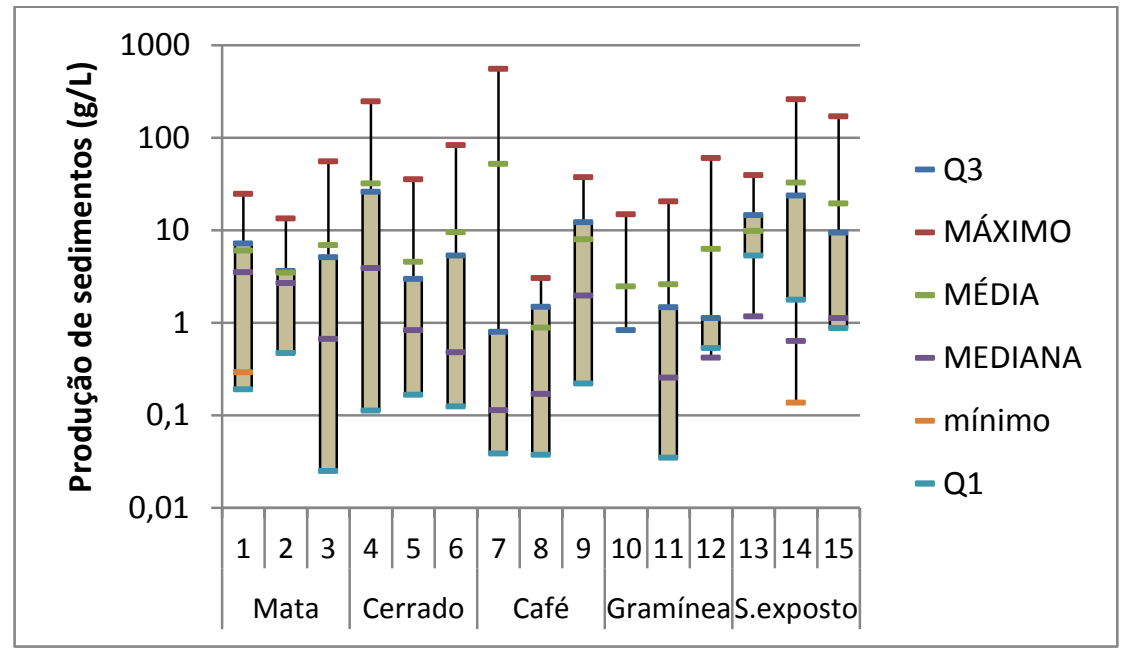

Figura 4.18 - Gráfico de caixa com a distribuição dos valores da produção de sedimentos (g/L) por parcela de erosão, por tipo de uso do solo

A Figura 4.18 mostra a distribuição da produção de sedimentos de cada uma das parcelas. A variável produção de sedimentos foi a que houve maior amplitude de valores, onde todas as parcelas de todos os usos do solo ficaram bem distintas umas das outras.

Com excessão de P1 e P14, todas as demais em algum momento não tiveram perda sedimentar, provavelmente por não ter havido escoamento. A parcela P7 do CF apresentou um valor discrepante, principalmente se comparada aos resultados encontrados em SE.

A Tabela 4.4 resume os resultados da pesquisa quantitativamente. Durante o período da pesquisa (10/12/2014 a 27/04/2015), foram perdidas cerca de 8.849.687,36 gramas de solo em 6 metros quadrados (total da área das três parcelas do Solo Exposto), com uma média de $1.474 .947,89 \mathrm{~g} / \mathrm{m}^{2}$. 
A Mata de Galeria gerou a perda de 1.372,29 g de sedimentos. Mesmo sendo um solo com baixa infiltração, o armazenamento da precipitação na copa das árvores e na serrapilheira contribuem para evitar e minimizar o escoamento superficial e a perda de sedimentos.

O Cerrado sofreu uma perda sedimentar da ordem de 9.042,19 g no total e média de $1.507,03 \mathrm{~g} / \mathrm{m}^{2}$. As parcelas do Café 27.522,53 g (média de 4.587,08 g/m²), e 6.876,03 g, e média de 1.146,00 g/m² das parcelas da Gramínea.

Tabela 4.4 - Total de massa de sedimentos transportada por área $\left(\mathrm{g} / \mathrm{m}^{2}\right)$

\begin{tabular}{|c|c|c|c|c|c|c|}
\hline \multicolumn{2}{|l|}{ Uso do Solo } & $s(g)$ & $f(L)$ & $a\left(m^{2}\right)$ & $c(L)$ & $M\left(g / m^{2}\right)$ \\
\hline \multirow{3}{*}{ Mata de Galeria } & P1 & 13,42 & 15,62 & 2,00 & 5,11 & 535,69 \\
\hline & P2 & 14,96 & 11,05 & 2,00 & 8,01 & 662,12 \\
\hline & P3 & 8,56 & 9,27 & 2,00 & 4,40 & 174,48 \\
\hline \multirow{3}{*}{ Cerrado } & P4 & 101,14 & 17,54 & 2,00 & 4,72 & $4.186,45$ \\
\hline & P5 & 11,37 & 81,22 & 2,00 & 6,06 & $2.797,27$ \\
\hline & P6 & 40,82 & 14,94 & 2,00 & 6,75 & $2.058,47$ \\
\hline \multirow{3}{*}{ Café } & P7 & 32,88 & 48,18 & 2,00 & 6,68 & $5.291,13$ \\
\hline & P8 & 8,13 & 32,45 & 2,00 & 4,70 & 619,83 \\
\hline & P9 & 95,44 & 59,28 & 2,00 & 7,64 & $21.611,57$ \\
\hline \multirow{3}{*}{ Gramínea } & P10 & 4,04 & 2,77 & 2,00 & 1,64 & 9,17 \\
\hline & P11 & 3,33 & 6,84 & 2,00 & 4,47 & 50,90 \\
\hline & P12 & 34,08 & 43,62 & 2,00 & 9,17 & $6.815,96$ \\
\hline \multirow{3}{*}{ Solo Exposto } & P13 & 3414,74 & 237,29 & 2,00 & 10,20 & 4.132.444,27 \\
\hline & P14 & 3512,62 & 195,53 & 2,00 & 10,24 & $3.516 .528,78$ \\
\hline & P15 & 1601,19 & 141,89 & 2,00 & 10,57 & $1.200 .714,31$ \\
\hline
\end{tabular}

Legenda: M - Relação de sedimento transportado por metro quadrado $\left(\mathrm{g} / \mathrm{m}^{2}\right), \mathrm{s}-$ Total de sedimentos transportados por parcela $(\mathrm{g}), \mathrm{f}-$ Total de escoamento superficial por parcela (L), a - Área da parcela experimental $\left(\mathrm{m}^{2}\right), \mathrm{c}$ - Quantidade de amostra coletada $(\mathrm{L})$.

Fonte: elaborado pela autora.

A Tabela 4.5 mostra a relação entre a altura de chuva precipitada $(\mathrm{mm})$, a altura de água escoada superficialmente $(\mathrm{mm})$, e a altura de água infiltrada $(\mathrm{mm})$ em cada parcela em 1 $\mathrm{m}^{2}$. Os usos do solo que tiveram o maior escoamento superficial, e consequentemente, menor infiltração, foram o Solo Exposto e o Café, também tendo as maiores perdas de sedimentos. A parcela P12 da Gramínea e a parcela P5 do Cerrado tiveram maior escoamento e menor infiltração em relação às demais parcelas do mesmo uso, o que parece não haver relação determinante com a declividade, visto que as inclinações destas parcelas não são as maiores de suas estações. Possivelmente a cobertura do solo ou a porcentagem de argila, no caso da parcela P5 seja mais relevante na explicação de maior escoamento superficial e menor infiltração, mas não de perda sedimentar. 
Tabela 4.5 - Precipitação (P), Escoamento Superficial (Q), Infiltração (I), Perda de Sedimentos (S), Declividade (D) e Porcentagem de Argila (\%) por $\mathbf{m}^{2}$, por Uso do Solo

\begin{tabular}{cccccccccc}
\hline N & $\begin{array}{c}\text { Uso do } \\
\text { Solo }\end{array}$ & $\mathrm{P}(\mathrm{mm})$ & $\begin{array}{c}\mathrm{Q} \\
(\mathrm{mm})\end{array}$ & $\begin{array}{c}\mathrm{Q} \\
(\%)\end{array}$ & $\begin{array}{c}\mathrm{I} \\
(\mathrm{mm})\end{array}$ & $\begin{array}{c}\mathrm{I} \\
(\%)\end{array}$ & $\mathrm{S}(\mathrm{g})$ & $\mathrm{D}\left({ }^{\circ}\right)$ & $\begin{array}{c}\% \\
\text { Argila }\end{array}$ \\
\hline P1 & Mata de & 719,6 & 3,9 & 0,5 & 715,7 & 99,5 & 6,5 & 20 & 40,42 \\
P2 & galeria & 719,6 & 2,8 & 0,4 & 716,8 & 99,6 & 8,2 & 13 & 47,86 \\
P3 & & 719,6 & 2,3 & 0,3 & 717,3 & 99,7 & 4,2 & 15 & 41,60 \\
P4 & & 719,6 & 4,4 & 0,6 & 715,2 & 99,4 & 50,6 & 9 & 65,02 \\
P5 & Cerrado & 719,6 & 20,3 & 2,8 & 699,3 & 97,2 & 5,7 & 22 & 79,20 \\
P6 & & 719,6 & 3,7 & 0,5 & 715,9 & 99,5 & 20,4 & 28 & 69,91 \\
P7 & & 718,4 & 12,0 & 1,7 & 706,4 & 98,3 & 16,4 & 18 & 66,11 \\
P8 & Café & 718,4 & 8,1 & 1,1 & 710,3 & 98,9 & 4,1 & 17 & 44,13 \\
P9 & & 718,4 & 14,8 & 2,1 & 703,6 & 97,9 & 47,7 & 21 & 79,58 \\
P10 & & 718,4 & 0,7 & 0,1 & 717,7 & 99,9 & 2,0 & 28 & 70,32 \\
P11 & Gramínea & 718,4 & 1,7 & 0,2 & 716,7 & 99,8 & 1,6 & 31 & 79,07 \\
P12 & & 718,4 & 10,9 & 1,5 & 707,5 & 98,5 & 17,0 & 23 & 70,69 \\
P13 & & 718,4 & 59,3 & 8,3 & 659,1 & 91,7 & $1.707,4$ & 26 & 70,82 \\
P14 & Solo & 718,4 & 48,9 & 6,8 & 669,5 & 93,2 & $1.756,3$ & 29 & 75,22 \\
P15 & & 718,4 & 35,5 & 4,9 & 682,9 & 95,1 & 800,6 & 22 & 70,32 \\
\hline & & & & & & & & \\
\hline
\end{tabular}

A parcela P12 tem menor declividade em relação à P10 e P11, e porcentagem de argila semelhante à P10, então a estrutura do solo e ou a organização da malha das raízes podem explicar as diferenças de escoamento superficial, infiltração e perda de sedimentos desta parcela.

A parcela P9 do Café apresentou maior escoamento, menor infiltração e maior perda sedimentar que as parcelas P7 e P8. Possivelmente, estejam relacionadas com a maior declividade e a maior porcentagem de argila encontradas em P9. Esta mesma relação parece existir no uso Solo Exposto demonstrada pela parcela P14.

\section{Conclusões}

A perda de sedimentos das parcelas de Solo Exposto mostram o tanto que a geração do escoamento superficial e produçao de erosão foram incrementados com a ausência de cobertura da superfície. Mesmo em solos com características de serem pouco suscetíveis à erosão e boa capacidade de infiltração, como é o caso dos Latossolos, ao serem expostos às condições climáticas, podem gerar grande erosão. A carga sedimentar transportada pelo Ribeirão do Gama, podendo ser depositada no Lago Paranoá, causando assoreamento e diminuindo a disponibilidade de água superficial, além da contaminação de suas águas. 
O cultivo de café em linhas, sem cobertura da base das plantas, também mostrou não ser uma prática agrícola conservacionista, pela alta geração de sedimentos, porém em porporção bastante menor que o solo Exposto. A gramínea mostrou eficiência de cobertura do solo, com baixos valores de escoamento superficial e perda de solos. O Cerrado e a Mata de Galeria evidenciam a importância de manutenção da vegetação nativa do Cerrado, pois permitem um equílibrio dos processos hidrogeomorfológicos.

As variáveis Escoamento Superficial, Perda de Sedimentos e Infiltração estão correlacionadas a diversos fatores, tais como, propriedades físicas do solo (granulometria, porosidade), condições climáticas, cobertura e uso do solo, declividade e comprimento de rampa, atividade biológica no solo, umidade do solo, sendo influenciados pela interação desses fatores e a relevância de cada um no sistema dever ser avaliado caso a caso.

A metodologia adotada pela pesquisa atendeu aos objetivos definidos, ao permitir mostrar as perdas reais de solos por meio do escoamento superficial, de forma quantitativa, e qualitativa. Dessa forma, pode-se ter mais subsídios ao planejamento e ordenamento territorial, e compreender melhor como é o comparmento hidrogemorfológico dos solos do Bioma Cerrado, em especial, do Distrito Federal.

Sugere-se que a mensuração das variáveis escoamento superficial e produção de sedimentos continue sendo realizada como forma de se criar uma série de anos consecutivos, e verificar como o comportamento hidrogeomorfológico e solos de Cerrado respondem às variações climáticas, tais como eventos extremos. Pode-se ampliar os tipos de solo e uso do solo, além de aumentar os parâmetros.

\section{REFERÊNCIAS BIBLIOGRÁFICAS}

ALMEIDA, B. G. de et al. Padronização de Métodos para Análise Granulométrica no

Brasil. Rio de Janeiro: Embrapa, 2012 (Comunicado técnico 66). 11 p.

BRADY, N. C.; WEIL, R. R. Elementos da natureza e propriedades dos solos. Tradução técnica: LEPSCH, I. F. 3 ed. Porto Alegre: Bookman, 686 p., 2013.

CARVALHO, A. P. F. de et al. Desenvolvimento de metodologia em SIG para zoneamento ecológico: estudo de caso da Bacia Ribeirão do Gama-DF. Planaltina: Embrapa Cerrados, 2001, Vol. 39, p. 19.

CHORLEY, R. J.; BECKINSALE, R. P. G.K. Gilbert's geomorphology. Geological Society of america. Special Paper, v. 183, 129-142, 1980. 
COELHO NETTO A. L. Hidrologia de encosta na interface com a geomorfologia. In: GUERRA A. J. T. \& CUNHA S. B. (Org.). Geomorfologia: uma atualização de bases econceitos. Rio de Janeiro: Bertrand Brasil, $5^{\mathrm{a}}$ ed., 2003.

DUNNE, T.; LEOPOLD, L. B. Water in Environmental Planning. W. H. Freeman Co., San Francisco, 1978, 818 p.

EMBRAPA. Serviço Nacional de Levantamento e Conservação de Solo. Levantamento de reconhecimento dos solos do Distrito Federal. Rio de Janeiro, EMBRAPA-SNLCS. 1978. 455p. (EMBRAPA-SNLCS. Boletim Técnico, 53).

EMBRAPA. Centro Nacional de Pesquisa de Solos. Manual de métodos de análise de solo. Centro Nacional de Pesquisa de Solos. - 2. ed. rev. atual. - Rio de Janeiro, 1997. 212 p. 1997.

FAV/UnB. Boletim Agroclimatologia 2014. Brasília, 1p. 2014. Disponível em: www.fav.unb.br. Visualizado em julho/15

REATTO, A. et al. Mapa pedológico digital - SIG atualizado do Distrito Federal escala 1:100.000 e uma síntese do texto explicativo. Planaltina: Embrapa Cerrados, 2004, 31p.

SATO, A. M.; AVELAR, A. de S. \& COELHO NETTO, A. L. Spatial variability and temporal stability of throughfall in a eucalyptus plantation in the hilly lowlands of southeastern Brazil. Hydrological Processes, v. 25, p. 1910-1923. 2011. 


\section{REFERÊNCIAS BIBLIOGRÁFICAS}

ALENCAR, D. B. S. d; SILVA, C. L. d.; OLIVEIRA, C. A. d. S. Influência da precipitação no escoamento superficial em uma microbracia hidrográfica do Distrito Federal. Eng. Agrícola, pp. 103-112, 2006.

ALMEIDA, B. G. de et al. Padronização de Métodos para Análise Granulométrica no Brasil. Rio de Janeiro: Embrapa, 2012 (Comunicado técnico 66). 11 p.

ALMEIDA, GI. C. P. Caracterização Física e Classificação dos Solos. http://www.ufrrj.br/institutos/it/deng/rosane/downloads/material\%20de\%20apoio/APOSTI LA_SOLOS.pdf. Acesso em 04/2014.

AVELAR, André de Souza. Características hidrológico-erosivas de solos em encostas montanhosas sob diferentes coberturas vegetais no município de Bananal (SP). Geo UERJ Revista do Departamento de Geografia. N.1 (jan. 1997) - Rio de Janeiro: UERJ, Departamento de Geografia, 1997 - v. Semestral, p. 596-605.

AZEVEDO, J.A. de; SILVA, E. M. da. Tensiômetro: dispositivo prático para controle da irrigação. Planaltina: Embrapa Cerrados. 33 p. , 1999. (Embrapa Cerrados. Circular Técnica, 001).

BEZERRA, J. F. R. Avaliação de geotexteis no controle da erosão superficial a partir de uma estação experimental, Fazenda do Glória - MG. 2006. 104 f. Dissertação (Mestrado em Geografia) - Universiadade Federal de Uberlândia, Programa de PósGraduação em Geografia, Uberlândia, , 2006.

BRADY, N. C.; WEIL, R. R. Elementos da natureza e propriedades dos solos. Tradução técnica: LEPSCH, I. F. 3 ed. Porto Alegre: Bookman, 686 p., 2013.

CARVALHO, A. P. F. de et al. Desenvolvimento de metodologia em SIG para zoneamento ecológico: estudo de caso da Bacia Ribeirão do Gama-DF. Planaltina: Embrapa Cerrados, 2001, Vol. 39, p. 19.

CARVALHO, A. C. et al., prelo. Mensuração e análise dos dados pluviométricos obtidos na área de bacia do ribeirão do Gama/DF e identificação de eventos extremos recorrentes na série histórica de dados, Brasília: s.n.

CARVALHO, F. H.; LACERDA, M. P. C.; SILVA, C. L. d.; LIMA, J. E. F. W.; CHAVES, A. A. A.; JÚNIOR, M. P. d. O. Predição de vazões em uma pequena bacia hidrográfica do Bioma Cerrado com utilização do Modelo Swat. p. 8, s/d. Disponível em: http://www.abrh.org.br/sgcv3/UserFiles/Sumarios/774e19b7e9a86cfa2dac74831fb97ccc 4ffc3471b27a7a7afaab6392ad6a5a8d.pdf. Visto em dez 2014.

CHORLEY, R. J. Geomorphology and general systems theory. United Satates Geological Survey Professional Paper, 500B, 10 p., 1962.

CHORLEY, R. J.; BECKINSALE, R. P. G.K. Gilbert's geomorphology. Geological Society of america. Special Paper, 183, 129-142, 1980.

COELHO NETTO A. L. Hidrologia de encosta na interface com a geomorfologia. In: GUERRA A. J. T. \& CUNHA S. B. (Org.). Geomorfologia: uma atualização de bases econceitos - exercícios, técnicas e aplicações. Rio de Janeiro: Bertrand Brasil, $4^{\mathrm{a}}$ ed., 2010. 
COELHO NETTO A. L. Hidrologia de encosta na interface com a geomorfologia. In: GUERRA A. J. T. \& CUNHA S. B. (Org.). Geomorfologia: uma atualização de bases econceitos. Rio de Janeiro: Bertrand Brasil, $5^{\text {a }}$ ed., 2003.

COMPANHIA DE SANEAMENTO AMBIENTAL DO DISTRITO FEDERAL (GOVERNO DO DISTRITO FEDERAL). Plano de Gestão e Preservação do Lago Paranoá: Produto 1 - Levantamento, Caracterização e Situação Atual. Brasília - DF, 2003.

COMPANHIA DE SANEAMENTO AMBIENTAL DO DISTRITO FEDERAL (GOVERNO DO DISTRITO FEDERAL). Estudo de Impacto Ambiental - EIA do Sistema de Abastecimento de Água com Captação no Lago Paranoá. Brasília - DF: CAESB, 2013. xxiv, 524 f.: il.

CREPANI, E.; MEDEIROS, J. S. d.; FILHO, P. H.; FLORENZANO, T. G.; DUARTE, V.; BARBOSA, C. C. F. Zoneamento Ecológico Econômico e ao Ordenamento Territorial, São José dos Campos: INPE, Rio de Janeiro, 2001. Disponível em: http://www.dsr.inpe.br/laf/sap/artigos/CrepaneEtAl.pdf. Visto em jan 2015.

Center for Watershed Protection. The Economic Connections Between Forests and drinking Water. Maryland, EUA: CWP. P. 1-40, 2011.

DIAS, MARIA ACCIOLY. Influência da topografia na dinâmica de bordas florestagramínea em um relevo montanhoso - maciço da Tijuca, RJ. 123 p. Dissertação de mestrado - PPGG - UFRJ, Rio de Janeiro, 2011.

DISTRITO FEDERAL, TERRACAP. Base Cartográfica, 2009.

DUNNE, T.; LEOPOLD, L. B. Water in Environmental Planning. W. H. Freeman Co., San Francisco, 818 p., 1978.

EMBRAPA. Serviço Nacional de Levantamento e Conservação de Solo. Levantamento de reconhecimento dos solos do Distrito Federal. Rio de Janeiro, EMBRAPA-SNLCS. 1978. 455p. (EMBRAPA-SNLCS. Boletim Técnico, 53).

EMBRAPA. Centro Nacional de Pesquisa de Solos. Manual de métodos de análise de solo. Centro Nacional de Pesquisa de Solos. - 2. ed. rev. atual. - Rio de Janeiro, 212 p. 1997.

FAV/UnB. Boletim Agroclimatologia 2014. Brasília, 1p. 2014. Disponível em: www.fav.unb.br. Visualizado em julho/15.

GARBIN, E. J; PINESE, J. F. J; RODRIGUES, S. C. Análise da variação da umidade em diferentes tipologias de uso da terra através do uso de parcelas de erosão. Fazenda Experimental do Glória - UBERLÂNDIA MG. In: VI Simpósio Nacional de Geomorfologia/Regional Conference on Geomorphology. Goiânia, GO. 11 p. 2006. Disponível em: http://www.labogef.iesa.ufg.br/links/sinageo/articles/149.pdf. Visto em out 2014.

GOERL, R. F.; KOBIYAMA, M.; SANTOS, I. d.. Hidrogeomorfologia: princípios, conceitos, processos e aplicações. Revista Brasileira de Geomorfologia, v. 13, n. 2, (Abr-Jun) p. 103-111, $2012 . \quad$ Disponível em: http://www.lsie.unb.br/rbg/index.php/rbg/article/view/166/288. Visto em jan 2015.

GOMI, T.; SIDLE, R. C.; UENO, M.; MIYATA, S.; KOSUGI, KRN'ICHIROU. Characteristics of overland flow generation on steep forested hillslopes of central Japan. Journal of Hydrology, p. 275-290, 2008. 
GUERRA A. J. T. Processos erosivos nas ecostas. In: GUERRA A. J. T. e CUNHA, S. B. (Org.). Geomorfologia: atualização de bases e conceitos.: Rio de Janeiro: Bertrand Brasil, 2003.

GUERRA, A. J. T.; MENDONÇA, J.K.S. Erosão dos solos e a questão ambiental. In: VITTE, A. C.; GUERRA, A. J. T. (Org.). Reflexões sobre a geografia física do Brasil. São Paulo: Bertrand Brasil, 2004.

GUERRA, A. J. T. O início do processo erosivo. In: GUERRA, A. J. T., SILVA, A. S. e BOTELHO, R. G. M. (Org.). Erosão e conservação dos solos - conceitos, temas e aplicações. Rio de Janeiro, Editora Bertrand Brasil, 5 edição, p. 15-55. 2010.

HORTON, R. E.; LEACH, H. R. \& VAN VLIET, R. Laminar sheet-Transections of the American Geophysical Union, $15^{\text {th }}$ annual, p. 393-404, 1934.

JARDIM, H. L.; FERNANDES, N. F. \& SOUZA, A. P. de. Estudo da perda de solo em parcelas de erosão sob diferentes culturas e técnicas de manejo e a análise de estratégias de conservação através da utilização do modelo WEPP. O caso de Paty do Alferes/RJ. In: VI Simpósio Nacional de Geomorfologia/ Regional Conference on Geomorphology. Goiânia, 2006. Disponível em: http://www.labogef.iesa.ufg.br/links/sinageo/articles/179.pdf. Visto em abr 2014.

JÚNIOR, J. F. P. et al. Monitoramento de processos erosivos em parcelas experimentais no município de Uberlândia, MG. Revista Geográfica Acadêmica, Uberlândia, v.2, n.3, 5$18,2008$.

LIMA, J. E. F. W, SILVA, C. L. d. \& OlIVEIRA, C. A. d. S. Comparação da evapotranspiração real simulada e observada em uma bacia hidrográfica em condições naturais de cerrado. Revista Brasileira de Engenharia Agrícola e Ambiental, p. 33-41, 2001.

LIMA, J. E. F. W.; SILVA, C. L. \& OLIVEIRA, C. A. d. S., s/d. Determinação da evapotranspiração de uma bacia hidrográfica sob vegetação de cerrado pelo método do balanço hídrico. s/nome, p. 15.

MARCHIORO E. e AUGUSTIN C.H.R.R. Dimensão de parcelas experimentais: influência nas medidas de escoamento superficial e erosão do solo em Gouveia/MG. Geografias Artigos Científicos. Belo Horizonte: Vol. 3, p. 7-16, julho-dezembro de 2007.

MARTINS, E. d. S. REATTO, A.; JÚNIOR, O. A. d. C.; GUIMARÃES, R. F. Evolução Geomorfológica do Distrito Federal. Planaltina: Embrapa Cerrados, 57p. 2004. Disponível em: www.cpac.embrapa.br/download/342/t. Visto em set 2014.

MENEZES , P. H. B. J. Avaliação do efeito das ações antrópicas no processo de escoamento superficial e assoreamento na Bacia do Lago Paranoá. $132 \mathrm{f}$. Dissertação (Mestrado em Geociências Aplicadas) - Instituto de Geociências da Universidade de Brasília, Brasília, 2010.

MINISTÉRIO DO MEIO AMBIENTE. Disponível em: http://www.mma.gov.br/biomas/cerrado. Acesso em abril/15.

MINOTI, R.T.; KOIDE, S.; LIPORONI, L M. Estimativa das cargas de sedimentos e nutrientes em duas sub-bacias do lago Paranoá Brasília/DF. In: XIX Simpósio Brasileiro de Recursos Hídricos. Anais. Maceió: ABRH. p. 1-19, 2011. 
MOURA L. H. A., BOAVENTURA G. R. e PINELli M. P. A qualidade da água como indicador de uso e ocupação do solo: Bacia do Gama - Distrito Federal. Química Nova. 2010. Vols. 33-1, p. 97-103.

MUTCHLER, C. K.; MURPHREE, C. E. \& MCGREGOR, K. C. Laboratory a field plots for soil erosion studies. In: Lal R (ed) Soil erosion research methods. Soil Water Conserv. soc., Ankeny, Iowa, v. 244, p. 9-36, 1988.

MYERS, N. et al. Biodiversity hotspots for conservation priorities. Nature. V. 403, p. 853$858,2000$.

NASCIMENTO, N. d. M. P. Interceptação de chuva pela vegetação do Cerrado. (Dissertação de Mestrado em Ecologia). Brasília: Universidade de Brasília Departamento de Ecologia-, 103 f. 1992.

NEGREIROS, A. B. Reabilitação funcional de clareira de deslizamento em encosta íngrime no domínio da Floresta Atlântica, Rio de janeiro (RJ). Revista Brasileira de Geomorfologia - v. 10, $\mathrm{n}^{\mathbf{0}}$ 1, 2009.

NEGREIROS, A. B. Recuperação de Floresta Atlântica e Resultante Hidro-Erosiva em Clareiras de Deslizamentos nas Encostas Íngremes do Maciço da Tijuca, RJ. Tese de Doutorado em Ciências. Rio de Janeiro: Universidade Federal do Rio de Janeiro, 2011. p. 145.

OKUNISHI, K. Hydrogeomorphological interactions: a review of approach and strategy. Transactions, Japanese Geomorphological Union, v. 2, p. 99-116, 1991.

OKUNISHI, K. Concept and methodology of hydrogeomorphology. Transactions, Japanese Geomorphological Union, v. 15A, p. 5-18, 1994.

PINESE, J. F. J; GARBIN, E. J; RODRIGUES, S. C. Análise do transporte de sedimentos com diferentes tipos de uso do solo em calhas de Erosão (1966) na Fazenda Experimental do Glória, Uberlândia - MG. In: VI Simpósio Nacional de Geomorfologia/Regional Conference on Geomorphology. Anais. Goiânia, GO. p. 09-11, 2006.

PINTO, M. N. (Org.) Cerrado: caracterização, ocupação e perspectivas. Brasília: Editora Universidade de Brasília, p. 657, 1990.

REATTO, A.; MARTINS, E. d. S.; SILVA, A. V. d.; JÚNIOR, O. A. d. C. Mapa pedológico digital - SIG atualizado do Distrito Federal escala 1:100.000 e uma síntese do texto explicativo. Planaltina: Embrapa Cerrados, 2004, 31p.

RESENDE, M.; CURI, N.; RESENDE, S.B. \& CORREAA, G.F. Pedologia: base para distinção de ambientes. Viçosa, MG, NEPUT, 1995. 304p

RIBEIRO, B. T. Energia cinética de gotas de chuva simulada e energia ultra-sônica na desagregação de um Cambissolo. Lavras, UFLA, 2006. p 65. Dissertação de Mestrado.

RIBEIRO, J. F.; WALTER, B.M.T. Fitofisionomias do bioma Cerrado. In: SANO, S. M.; ALMEIDA, S. P. (Org.). Cerrado: ambiente e flora. Planaltina, DF: Embrapa- CPAC, 1998. Cap. 3, p. 89-166.

SANTOS, C. A. G.; SUZUKI, K.; WATANABE, M.; SRINIVASAN, V. S. Influência do tipo da cobertura vegetal sobre a erosão no semi-árido paraibano. Revista Brasileira de engenharia Agrícola e Ambiental, v. 4, n. 1, p. 92-96, 2000. 
SANTOS, L. L. Quantificação do escoamento superficial e erosão do solo em regiões semiáridas. Revista Brasileira de Geografia Física. Recife-PE, vol. 2, nº 2, jan/abril, 2009, p. $14-25$.

SATO, A. M. Resposta geo-hidrológicas à substituição de pastagens por plantações de eucalipto no médio vale do Rio Paraíba do Sul. Rio de Janeiro: Universidade Federal do Rio de Janeiro, Departamento de Geografia - Programa de Pós-Graduação. Dissertação de Mestrado. p. 159, 2008.

SATO, A. M.; AVELAR, A. de S.; COELHO NETTO, A. L. Spatial variability and temporal stability of throughfall in a eucalyptus plantation in the hilly lowlands of southeastern Brazil. Hydrological Processes. v. 25, p. 1910-1923, 2011.

SILVA, C. L. d. Análise estatística das características de vazão do córrego Capetinga. Revista Brasileira de Engenharia Agrícola e Ambiental, 2003, 7(2), p. 311-317.

TRICART, J, 1977. Ecodinâmica. Rio de Janeiro: IBGE, Diretoria Técnica, SUPREN.

TUCCI, C. E. M.; MENDES, C. A. Avaliação ambiental integrada de bacia hidrográfica. Brasília-DF, Ministério do Meio Ambiente. p. 302, 2006.

UNESCO. Subsídios ao zoneamento da APA Gama-Cabeça de Veado e Reserva da Biosfera do Cerrado: caracterização e conflitos socioambientais. - Brasília: UNESCO, MAB, Reserva da Biosfera do Cerrado, 2003. p. 176.

ZHENG, H.; CHEN, F.; OUYANG, Z.; TU, N.; XU, W.; WANG, X.; LI, X.; TIAN, Y. Impacts of reforestation approaches on runoff control in the hilly red soil region of Southern China. Journal of Hydrology (2008) v. 356, p. 174-184. Disponível em: http://www.sciencedirect.com/science/article/pii/S0022169408001807. Visto em set 2014. 